

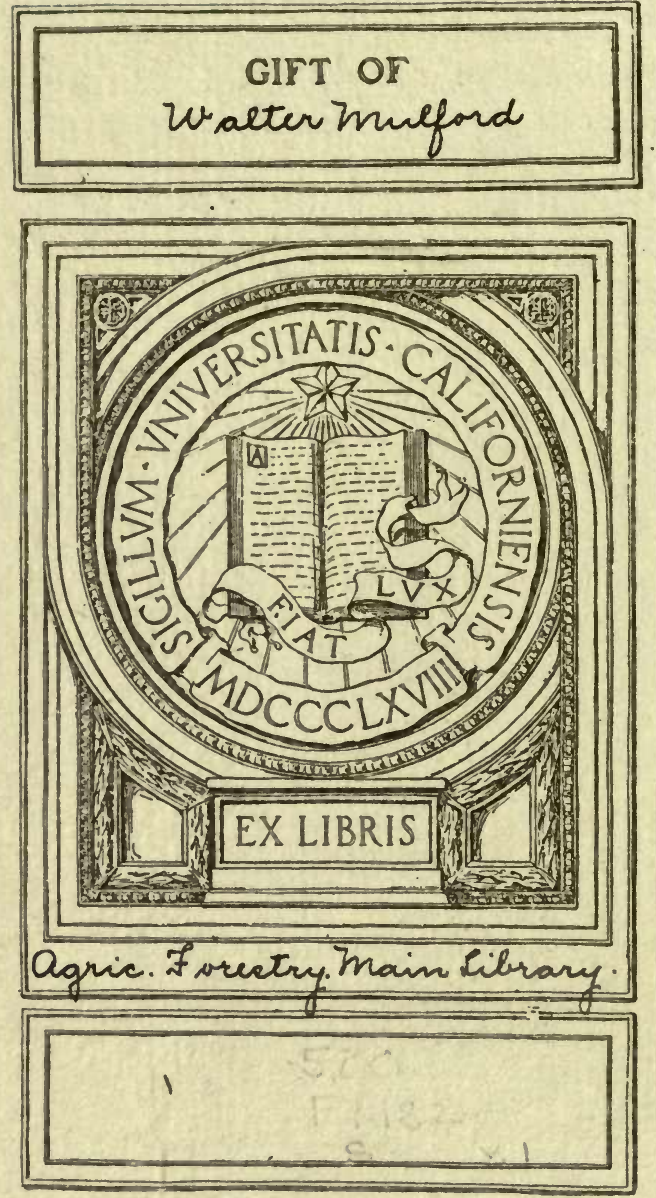




\section{TREES FOR LONG ISLAND}

STOGK LIST

March • 1909

\section{adrstbury $\mathfrak{A u r s e r i e s}$}

ISAAC HICKS \& SON

Westbury Station, Nassau County, Long Island, New York

\section{BUSINESS TERMS}

PRICES. The prices in this list are for trees and plants dug and loaded at Westbury Nurseries. Five, 50, and 500 plants at the 10,100, and 1,000 rates, respectively. Selected specimens at advanced price, according to quality of plant chosen. Items left unpriced are generally large specimens that are usually priced to include delivery on tree-mover and planting. Prices subject to change without notice.

DELIVERY. Prices on ordinary-sized nursery stock are usually for stock dug and loaded at the Nursery. Delivery by wagon is charged aceording to distance and expense. Stock to be shipped by freight or express will be carefully packed in straw bales and boxes, charged at cost of material and labor. Delivery to railroad is free, where our responsibility ceases.

Large trees on a tree-mover, and large evergreens, are priced, by correspondence, as follows: (1) To include delivery and planting in hole prepared by us; (2) to include delivery and planting when hole is prepared and assistance rendered by purchaser; or, (3) delivery and planting charged by the day.

TERMS OF PAYMENT-Net Cash. Accounts will be subiect to sight draft sixty days from the date of shipment. Unknown correspondents should send satisfactory referenee or eash with order. Money orders may be obtained for Westbury Station, Nassau county, New York.

WE DESIRE THAT ALL OUR CUSTOMERS BE FULLY SATISFIED, and wish to be promptly notified any errors that they may be rectified. We do not agree to consider complaints later than ten days after delivery.

TRUE TO NAME. Without boasting infallibility, we warrant our stock true to name, and will replace any that may prove otherwise, or refund the original price, but we will not be held responsible for more than the original price of the trees.

SUBSTITUTION. Late in the season we may be out of some varieties and sizes of fruit and other trees, and will substitute similar varieties and sizes unless otherwise ordered.

GUARANTEE. The living of trees is largely dependent upon eonditions of weather and after-care beyond the nurseryman's control; therefore, we do not guarantee trees to live after leaving the Nursery in good condition, without previous agreement and special price. If guarantee is desired, customers are requested to so state when asking prices.

OBJECT OF THIS PRICE-LIST. By giving quantities in this list, our aim is to enable customers to order stoek on hand, thus avoiding delay and disappointment. It shows dimensions of large specimens in sizes never before offered by nurseries, which save from fifteen to forty years of waiting. In offering smaller and cheaper stock, grown from Long Island and Northern seed, that fits the conditions and is hardy, we enable the purchaser to obtain results with the minimum outlay.

Address all orders to Isaac Hicks \& Son, Westbury Station, Nassau county, New York. Local and long-distance telephone, 68 Westbury. Telegraphic address, Westbury Station, New York.

For large trees, see Ash, Birch, Catalpa, Elm, Linden, Maple, Oak, Poplar, Tulip, Cedar, Fir, Hemlock, Pine, Retinospora, Spruce.

For larger trees and varieties not listed, write us. 


\section{Deciduous Trees}

ANDROMEDA to BEECH.

Andromeda arborea (Sorrel Tree);syn., Oxydendron arboreum. $2 \mathrm{ft}$. high

$4 \mathrm{ft}$. high

5 to $7 \mathrm{ft}$. high

$10 \mathrm{ft}$. high

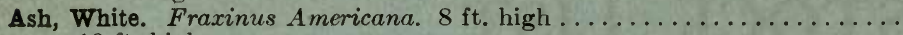
$10 \mathrm{ft}$. high

$12 \mathrm{ft}$. high

$14 \mathrm{ft}$. high

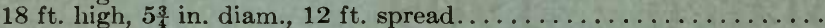

$22 \mathrm{ft}$. high, $4 \frac{1}{2}$ in. diam., $12 \mathrm{ft}$. spread.

$28 \mathrm{ft}$. high, $4 \frac{1}{2}$ to 5 in. diam., 8 to $10 \mathrm{ft}$. spread

$30 \mathrm{ft}$. high, $5 \mathrm{in}$. diam., $14 \mathrm{ft}$. spread.

$32 \mathrm{ft}$. high, $8 \frac{1}{2}$ in. diam., $15 \mathrm{ft}$. spread

$38 \mathrm{ft}$. high, $5 \frac{3}{4}$ in. diam., $14 \mathrm{ft}$. spread.

Ash, European (English). F. excelsior. $10 \mathrm{ft}$. high

$12 \mathrm{ft}$. high

$14 \mathrm{ft}$. high

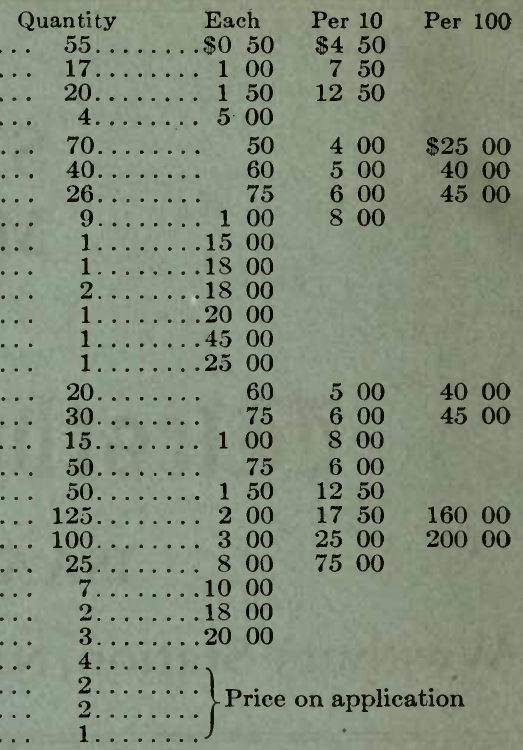

Beech, English, or European. Fagus sylvatica. $4 \mathrm{ft}$ high $\ldots \ldots \ldots \ldots \ldots$ $5 \mathrm{ft}$. high

$6 \mathrm{ft}$. high

$8 \mathrm{ft}$. high

$10 \mathrm{ft}$. high, 2 to $6 \mathrm{ft}$. spread

$12 \mathrm{ft}$. high, 2 to $5 \mathrm{ft}$. spread

$12 \mathrm{ft}$. high, 9 to $10 \mathrm{ft}$. spread

$14 \mathrm{ft}$. high, 6 to $8 \mathrm{ft}$. spread .

$16 \mathrm{ft}$. high, 6 to $10 \mathrm{ft}$. spread

$18 \mathrm{ft}$. high, 10 to $12 \mathrm{ft}$. spread

$20 \mathrm{ft}$. high, 14 to $16 \mathrm{ft}$. spread

$26 \mathrm{ft}$. high, 9 in. diam., $18 \mathrm{ft}$. spread

The American and European Ash, 8 to 14 feet, are good strect trees, valuable for real estate subdivisions. They are straight-trunk trees, with good roots and are priced low.

Beech, Rivers' Purple. F. sylvatica, var. purpurea Riversii.

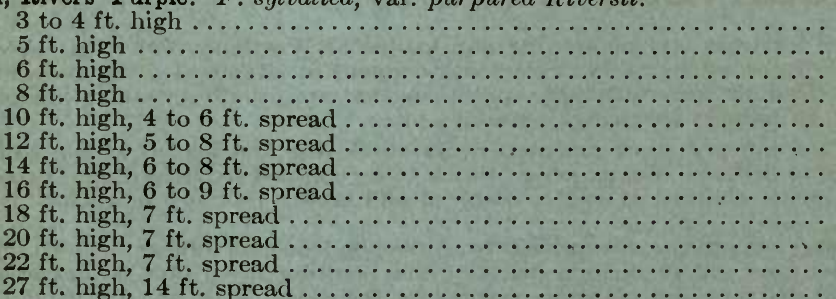

$5 \mathrm{ft}$. high ....

$6 \mathrm{ft}$. high

$16 \mathrm{ft}$. high, 6 to $9 \mathrm{ft}$. spread

$27 \mathrm{ft}$. high, $74 \mathrm{ft}$. spread Beech, European Weeping. $F$. sylvatica, var. pendula $4 \mathrm{ft}$. high $\ldots \ldots \ldots$

$8 \mathrm{ft}$. high

$10 \mathrm{ft}$. high, 1 to $2 \frac{1}{2}$ in. diam

$14 \mathrm{ft}$. high, $1+$ to 21 in diam 2 to 6 ft spread $\ldots \ldots \ldots \ldots \ldots$

Beech, Weeping, Purple. $F$. sylvatica, var. purpurea pendula. $3 \mathrm{ft}$. high. $6 \mathrm{ft}$. high

$12 \mathrm{ft}$. high, $4 \mathrm{ft}$. spread

These Weeping Beech are excellent trees for planting to arch a walk, at the same time forming a tall mass of beautiful foliage, rising perhaps 50 feet in height.

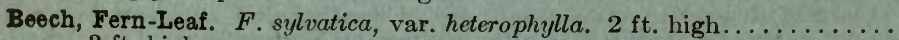

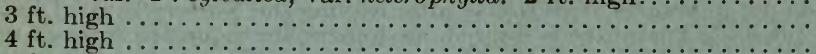

$5 \mathrm{ft}$. high

$6 \mathrm{ft}$. high

$10 \mathrm{ft}$, high, $6 \mathrm{ft}$.

$14 \mathrm{ft}$. high, $8 \mathrm{ft}$. spread

The Fern-Leaf Beech is a gem of the first water, and this stock cannot be surpassed in quality.

Beech, American. $F$. ferrunginea, $1 \mathrm{ft}$ high

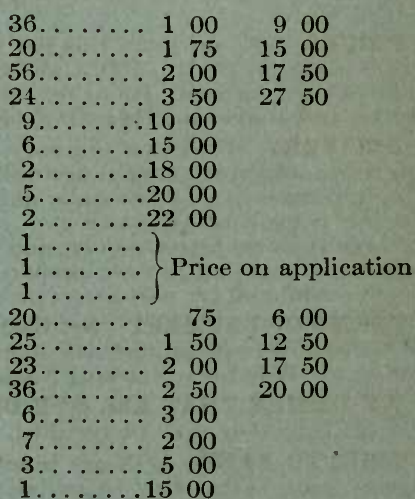

$50 \ldots \ldots \ldots 100$

$50 \ldots \ldots \ldots 150$

$7 \ldots \ldots \ldots 250$

$24 \ldots \ldots \ldots 500$

$29 \ldots \ldots \ldots 6600$

$12 \ldots \ldots 7700$

$1 \ldots \ldots \ldots 1500$

$1 \ldots \ldots \ldots 1800$

750

1250

2000

4000

5000

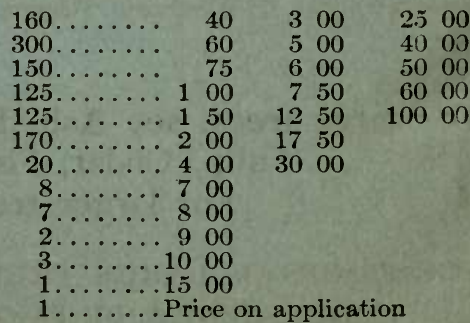


DECIDUOUS TREES, BIRCH to DOGWOOD.

Birch, Red, or River. Betula nigra. $30 \mathrm{ft}$. high, 9 in. diam., $30 \mathrm{ft}$. spread.

Quantity Each $2 \ldots \ldots \$ 4500$

Birch, European White. B. alba. $6 \mathrm{ft}$. high.

$12 \mathrm{ft}$. high, 6 to $9 \mathrm{ft}$. spread .

$16 \mathrm{ft}$. high, 23 in. diam., 7 to $9 \mathrm{ft}$. spread

$32 \mathrm{ft}$. high, $9 \frac{3}{4}$ in. diam., $15 \mathrm{ft}$. spread...

$36 \mathrm{ft}$. high, $8 \frac{1}{2}$ to $11 \frac{1}{2}$ in. diam., $20 \mathrm{ft}$. spread

$38 \mathrm{ft}$. high, 10 in. diam., $22 \mathrm{ft}$. spread...........

Birch, Cut-leaved Weeping. B. alba, var. pendula laciniata. $8 \mathrm{ft}$. high.

Birch, Cherry, Sweet, or Black. B. lenta. $4 \mathrm{ft}$. high.

$6 \mathrm{ft}$. high

$14 \mathrm{ft}$. high, $1 \frac{3}{1}$ to 3 in. diam., 6 to $8 \mathrm{ft}$. spread

$18 \mathrm{ft}$. high, $2 \frac{1}{4}$ to $5 \frac{1}{2} \mathrm{in}$. diam., $10 \mathrm{ft}$. spread .

Birch, Yellow. B. lutea. $8 \mathrm{ft}$. high, $4 \mathrm{ft}$. spread $10 \mathrm{ft}$. high, $1 \frac{1}{2} \mathrm{in}$. diam., $4 \mathrm{ft}$. spread.

$12 \mathrm{ft}$. high, $1 \frac{1}{2}$ in. diam., $4 \mathrm{ft}$. spread.

Catalpa, Western. Catalpa speciosa. $4 \mathrm{ft}$. high

$6 \mathrm{ft}$. high

$8 \mathrm{ft}$. high

$10 \mathrm{ft}$. high, $1 \frac{3}{4}$ to $2_{4}^{3} \mathrm{in}$. diam., 4 to $8 \mathrm{ft}$. spread

$12 \mathrm{ft}$. high, $1 \frac{1}{2}$ to $3 \frac{1}{4}$ in. diam., 4 to $8 \mathrm{ft}$. spread

$14 \mathrm{ft}$. high, 2 to 4 in. diam., 6 to $10 \mathrm{ft}$. spread

$16 \mathrm{ft}$. high, 3 to $5 \frac{1}{2}$ in. diam., 6 to $10 \mathrm{ft}$. spread

20 to $32 \mathrm{ft}$. high, 8 to $10 \mathrm{in}$. diam., 10 to $22 \mathrm{ft}$. spread

24 to $30 \mathrm{ft}$., 10 to $12 \mathrm{in}$. diam., 10 to $16 \mathrm{ft}$. spread.

28 to $32 \mathrm{ft}$. high, 12 to $14 \mathrm{in}$. diam., 18 to $20 \mathrm{ft}$. spread

$28 \mathrm{ft}$. high, $14 \frac{1}{2}$ in. diam., 12 to $18 \mathrm{ft}$. spread

Catalpa Bungei. C. bignonioides, var. nana. Standard, or Tree Form.

$6 \mathrm{ft}$. high
$8 \mathrm{ft}$. high

These large Catalpas are illustrated on page 14 . They have been been cut back to make dense, symmetrical specimens, and will give the maximum amount of shade for the cost. If you wish a big tree planted in May, this species is available.

Cherry, Pink Double-flowering Japanese. Prunus Pscudo-cerasus.

$3 \mathrm{ft}$. high

$6 \mathrm{ft}$. high

$10 \mathrm{ft}$. high, $1 \frac{1}{4}$ to 4 in. diam., 6 to $9 \mathrm{ft}$. spread

$14 \mathrm{ft}$. high, $3 \frac{1}{2}$ to $4 \frac{1}{2}$ in. diam., 8 to $10 \mathrm{ft}$. spread

Cherry, Japanese Weeping Rose-flowered. P. pendula. $6 \mathrm{ft}$. high, 2 in. diam., $6 \mathrm{ft}$. spread.

Cherry, Wild. P. serotina. 6 in. high, 1-yr. seedlings $1 \mathrm{ft}$. high $6 \mathrm{ft}$. high

Chestnut, American. Castanea Americana. $2 \mathrm{ft}$ high $4 \mathrm{ft}$. high

$6 \mathrm{ft}$. high

$8 \mathrm{ft}$. high

Chestnut, Japanese. C. crenata. $2 \mathrm{ft}$. high

$4 \mathrm{ft}$. high

$6 \mathrm{ft}$. high

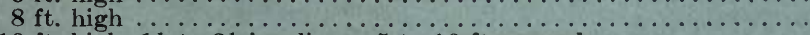

$10 \mathrm{ft}$. high, $1 \frac{1}{4}$ to $3 \frac{1}{4}$ in. diam., 5 to $10 \mathrm{ft}$. spread

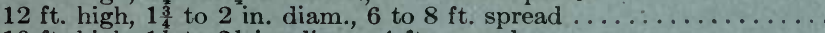

$10 \mathrm{ft}$. high, $1 \frac{1}{4}$ to $2 \frac{1}{2}$ in. diam., $4 \mathrm{ft}$. spread

Chestnut, Japanese Mammoth. $8 \mathrm{ft}$. high

Japanese Chestnuts have beautiful masses of foliage suitable for any lawn, and bear nuts when 6 feet ligh. Its nearly complete immunity from the Chestnut disease makes it especially valuable for planting at this time.

Chestnut, Paragon. C. sativa. $12 \mathrm{ft}$. high, $2 \frac{1}{2}$ in. diam., $8 \mathrm{ft}$. spread...... Chestnut, Chinquapin. C. pumila. $2 \mathrm{ft}$

Dogwood, Flowering. Cornus florida. 8 to 15 in. high, 1-yr. seedlings .

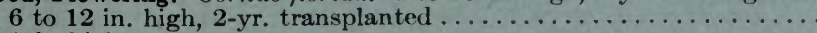
$2 \mathrm{ft}$. high.

$3 \mathrm{ft}$. high

$4 \mathrm{ft}$. high

$5 \mathrm{ft}$. high

$6 \mathrm{ft}$. high

$8 \mathrm{ft}$. high

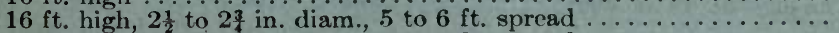

$18 \mathrm{ft}$. high, $3 \frac{1}{3}$ to $3 \frac{3}{4}$ in. diam., 7 to $8 \mathrm{ft}$. spread

Dogwood, Red-flowering. $C$. florida, var. rubra. $2 \mathrm{ft}$ high........... $3 \mathrm{ft}$. high

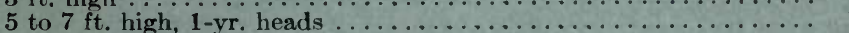

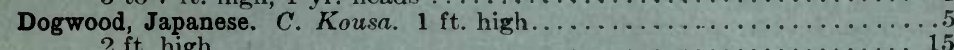

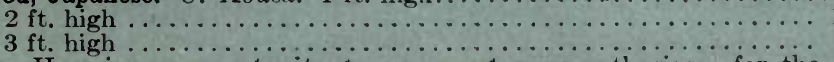

Here is an opportunity to carry out your enthusiasm for the Dogwood. We offer them at very low rates; handsome, straight, wellrooted trees, which may be planted in large groups.

$2 \ldots \ldots \ldots 200$

$2 \ldots \ldots .400$

$2 \ldots \ldots .4000$

$2 \ldots \ldots 4500$

$1 \ldots \ldots 6000$

$12 \ldots \ldots 125$

$25 \ldots \ldots 25$

$15 \ldots \ldots \ldots, 50$

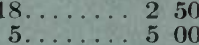

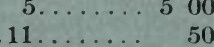

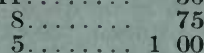

$250 \ldots \ldots 30$

$50 \ldots \ldots \ldots+45$

$60 \ldots \ldots 66$

$41 \ldots \cdots, 75$

$18 \ldots \ldots \ldots 1150$

$6 \ldots \ldots \ldots 400$

$11 \ldots \ldots .1800$

$16 \ldots \ldots 2500$

$3 . \ldots .3500$

$2 \ldots \ldots 4500$

$15 \ldots \ldots \ldots 125$

$11 \ldots \ldots \ldots 150$

Per 10 Per 100

$\$ 400$

$\begin{array}{ll}2 & 00 \\ 4 & 00\end{array}$

1500

400

$250 \$ \$ 2000$

$400 \quad 3500$

500

600

1250

$4 \ldots \ldots \ldots 100$

$5 \ldots \ldots \ldots 200$

$4 \ldots \ldots \ldots 500$

$2 \ldots \ldots 1000$

1...... 300

$60 \ldots \ldots 00$

$35 \ldots \ldots \ldots \quad 10$

$10 \ldots \ldots \ldots$

$100 \ldots \ldots$. 08

$150 \ldots \ldots 18$

$50 \ldots \ldots .40$

$50 \ldots \ldots \ldots 75$

$50 \ldots \ldots 25$

$50 \ldots \ldots \quad 50$

$80 \ldots \ldots 100$

$100 \ldots \ldots \ldots 125$

$15 \ldots \ldots \ldots 200$

5...... 300

$4 \ldots \ldots \ldots 250$

$3 \ldots \ldots \ldots 200$

400

400
60

160

300

600

200

400

800

1000

8000

3...... 300

$30 \ldots \ldots 660$

$800 \ldots \ldots \ldots 05$

$150 \ldots \ldots \ldots 10$

$50 \ldots \ldots \ldots 20$

$100 \ldots \ldots \ldots$

$240 \ldots \ldots \ldots$

$250 \ldots \ldots$

$300 \ldots \ldots .75$

$200 \ldots \ldots \ldots 100$

125

$\begin{array}{lll}3 & 00\end{array}$

500

75

100

50

20

35

175

300

2500

500

1500

500

175

200

250

350

600

800

1000

300

600

1750

2000

3000

5000

7000

$17 \ldots \ldots \ldots 50$ 
DECIDUOUS TREES, ELIM to LARIX.

Elm, American. Ulmus Americana. $6 \mathrm{ft}$. high

Quantity

Each

Per 10

Per 100

$8 \mathrm{ft}$. high

$10 \mathrm{ft}$. high, 1 to $2 \frac{1}{2}$ in. diam..

$12 \mathrm{ft}$. high, $1 \frac{1}{4}$ to $2 \frac{3}{4}$ in. diam.

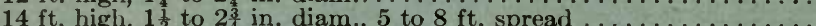

$16 \mathrm{ft}$. high, 2 to $3 \frac{1}{2}$ in. diam., 5 to $9 \mathrm{ft}$. spread

$18 \mathrm{ft}$. high, 2 to $4 \mathrm{in}$. diam., 4 to $11 \mathrm{ft}$. spread

$20 \mathrm{ft}$. high, $2 \frac{1}{2}$ to $4 \mathrm{in}$. diam., 4 to $12 \mathrm{ft}$. spread .

$22 \mathrm{ft}$. high, $2 \frac{1}{2}$ to 4 in. diam., 3 to $14 \mathrm{ft}$. spread

$24 \mathrm{ft}$. high, 3 to 4 in. diam., 3 to $12 \mathrm{ft}$. spread

$28 \mathrm{ft}$. high, 5 to 6 in. diam., 8 to $24 \mathrm{ft}$. spread . . . . . . . . . . . . . . .

$28 \mathrm{ft}$. high, $12 \frac{1}{2}$ in. diam.

$32 \mathrm{ft}$. high, $6 \frac{1}{2}$ in. diam., $12 \mathrm{ft}$. spread

$36 \mathrm{ft}$. high, 8 to $11 \frac{1}{2} \mathrm{in}$. diam., 9 to $15 \mathrm{ft}$. spread

$38 \mathrm{ft}$. high, 11 to $13 \mathrm{in}$. diam., 15 to $26 \mathrm{ft}$. spread

$40 \mathrm{ft}$. high, $14 \mathrm{in}$. diam., $24 \mathrm{ft}$. spread.

Elm, Weeping. U. Americana, var. pendula.

$12 \mathrm{ft}$. high, $1 \frac{1}{4}$ to $2 \frac{1}{2}$ in. diam..

$16 \mathrm{ft}$. high, 2 to $3 \frac{1}{4}$ in. diam., 6 to $7 \mathrm{ft}$. spread

$20 \mathrm{ft}$. high, $2 \frac{1}{2}$ to 5 in. diam., 5 to $12 \mathrm{ft}$. spread

$30 \mathrm{ft}$. high, $11 \frac{1}{2} \mathrm{in}$. diam., $30 \mathrm{ft}$. spread.

Elm, English. $U$. Campestris. $6 \mathrm{ft}$. high .

$18 \mathrm{ft}$. high, $5 \frac{1}{2}$ in. diam., $12 \mathrm{ft}$. spread.

Ginkgo biloba (Maidenhair Tree); syn., Salisburia adiantifolia.

$1 \mathrm{ft}$. high

$2 \mathrm{ft}$. high

$4 \mathrm{ft}$. high

$6 \mathrm{ft}$. high

$8 \mathrm{ft}$. high

$10 \mathrm{ft}$. high, 1 to 2 in. diam.

$12 \mathrm{ft}$. high, 1 to $2 \frac{3}{4}$ in. diam., 4 to $6 \mathrm{ft}$. spread

$60 . \ldots \ldots \$ 050$

$59 \ldots \ldots \ldots 60$

$47 \ldots \ldots \cdots 100$

$50 \ldots \ldots \cdots 125$

$66 \ldots \ldots \ldots 200$

$51 \ldots \ldots .300$

$31 \ldots \ldots \ldots 500$

$50 \ldots \ldots 6600$

$50 \ldots \ldots \ldots 800$

$12 \ldots \ldots 1200$

$5 \ldots \ldots 1500$

$1 \ldots \ldots .5000$

$1 \ldots \ldots 2500$

$3 \ldots \ldots 6000$

$3 \ldots \ldots 7500$

$1 \ldots \ldots 9000$

$6 \ldots \ldots \ldots 175$

$8 \ldots \ldots .250$

$7 \ldots \ldots \ldots 400$

$1 \ldots \ldots .8000$

$10 \ldots \ldots \ldots \quad 35$

$7 \ldots \ldots \times 8$
$1 \ldots \ldots$

250

500

$14 \mathrm{ft}$. high, 2 to $3 \frac{1}{2}$ in. diam., 4 to $7 \mathrm{ft}$. spread

$220 \ldots \ldots \ldots$

225

250

$\begin{array}{lll}6 & 00 \\ 7 & 50\end{array}$

750

$30 \ldots \ldots \cdots, 75$

$75 \ldots \ldots \ldots 100$

$75 \ldots \ldots \ldots 175$

1600

1800

$20 \ldots \ldots \ldots 300 \quad 2500$

$16 \mathrm{ft}$. high, $2 \frac{1}{2}$ to $3 \frac{1}{2}$ in diam., 4 to $8 \mathrm{ft}$. spread

$\begin{array}{llll}20 \ldots \ldots \ldots & 3 & 00 \\ 18 \ldots \ldots \ldots & 5 & 00\end{array}$

$13 \ldots \ldots 800$

$8 \ldots \ldots 1000$

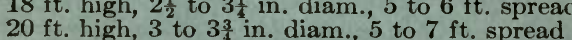

$3 \ldots \ldots 1200$

Hickory, Mockernut. Hickoria tomentosa; syn., Carya tomentosa.

3 to 9 in. high, 3 -yr. transplanted ...................... 10

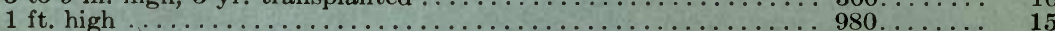

$3 \mathrm{ft}$. high

$50 \ldots \ldots \ldots .75$

Hickory, Shagbark. $H$ alba ; syn., $C$. alba.

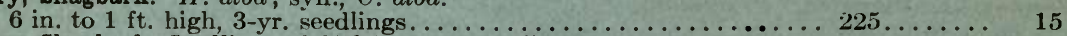

Hickory, Shagbark, Seedlings of Hale's Paper-shell.

6 to 12 in., 3-yr. seedlings

Hickory, King Nut. $H$. laciniosa. 6 to 12 in. high, 3 -yr. seedlings

Hickory, Pecan Nut. Carya olivoeformis. 1 to $2 \mathrm{ft}$., 3-yr. seedlings

2 ft., 3-yr. seedlings

The Hickory is one of the sturdiest native trees, and, when wel established, will maintain a good rate of growth. Here is an unsuual opportunity to start them at low rates.

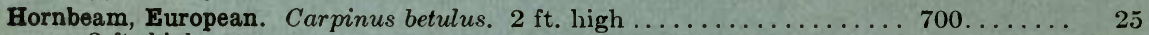
$3 \mathrm{ft}$. high $\ldots \ldots \ldots \ldots \ldots \ldots \ldots \ldots \ldots \ldots \ldots$

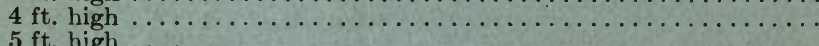

$5 \mathrm{ft}$. high

$500 \ldots \ldots \ldots 50$

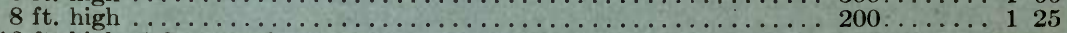

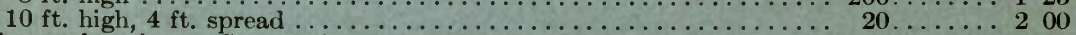

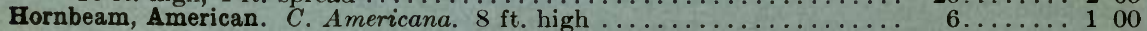

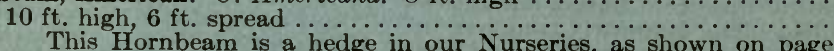

$6 \ldots \ldots \ldots 10$

16. It has held its leaves all winter, making a far better screen than privet. It has been repeatedly sheared, and last year it was rootpruned.

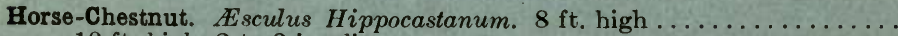

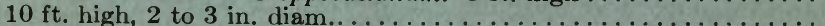

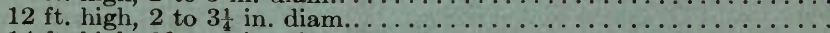

$14 \mathrm{ft}$. high, $2 \frac{3}{4}$ to 5 in. diam., 5 to $9 \mathrm{ft}$. spread $\ldots \ldots \ldots \ldots \ldots \ldots \ldots \ldots \ldots$

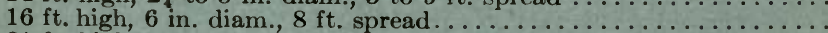

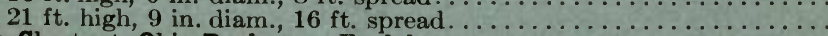

Horse-Chestnut, Ohio Buckeye. AE. glabra.

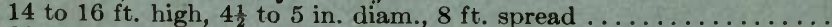

20 to $22 \mathrm{ft}$. high, $5 \frac{1}{2}$ in. diam., 10 to $12 \mathrm{ft}$. spread $\ldots \ldots \ldots \ldots \ldots \ldots$

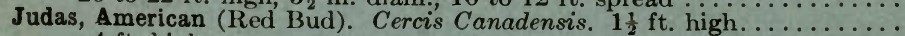
$4 \mathrm{ft}$. high $6 \mathrm{ft}$. high

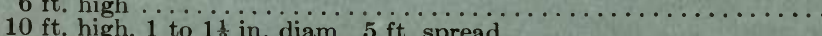

Kentucky Coffee Tree. Gymnocladus Canadensis.

28 to $30 \mathrm{ft}$. high, $8 \mathrm{in}$. diam., 17 to $21 \mathrm{ft}$. spread

Kœlreuteria (Varnish Tree). Kalreuteria paniculata 2 ft $\ldots \ldots \ldots \ldots \ldots$ $8 \mathrm{ft}$. high

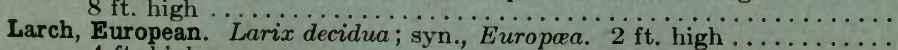
$4 \mathrm{ft}$. high.

Larix leptolepsis. $3 \mathrm{ft}$. high....

$22 \mathrm{ft}$. high, $14 \mathrm{ft}$. spread

$5 \ldots \ldots \ldots 125$

$10 \ldots \ldots \ldots 225$

$11 \ldots \ldots \ldots 400$

$19 \ldots \ldots 6600$

$1 \ldots \ldots 1800$

$1 \ldots \ldots .4000$

225

350

450

700

800

1000

$\$ 2000$

2250

90

1.20

800

1000

125

1000

400

90
180

500

1500

2......10 00

$2 \ldots \ldots \ldots 1200$

$150 \ldots \ldots 20$

$5 \ldots \ldots \ldots \quad 50$

$5 \ldots \ldots, 75$

$4 \ldots \ldots \ldots 100$

$2 . \ldots \ldots 2000$

$24 \ldots \ldots \ldots{ }^{75}$

$3 \ldots \ldots \ldots 100$

$25 \ldots \ldots \ldots 25$

$10 \ldots \ldots \ldots 50$

$20 \ldots \ldots \ldots 55$

$1 \ldots \ldots \ldots 2500$

2000

$\begin{array}{lll}35 & 00\end{array}$

5000

150

1400

2000

3000

4000

6500

7500

9000 
DECIDUOUS TREES, LARCH to MAGNOLIA.

Larch, Japanese. Pseudo-Larix Kampferi; syn., L. Kampferi. 3 to 6 in. high., 4 yr

Linden, Silver. Tilia tomentosa; syn., T. argentea; syn., $T$. alba.

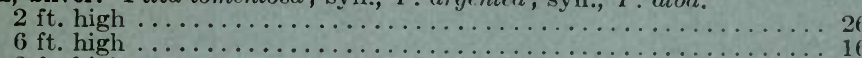
$8 \mathrm{ft}$. high

$10 \mathrm{ft}$. high, $1 \frac{1}{4}$ to $2 \frac{1}{2}$ in. diam.

$12 \mathrm{ft}$. high, 2 to $2 \frac{3}{4}$ in. diam.

$14 \mathrm{ft}$. high, 2 to $3 \frac{3}{4}$ in. diam., 3 to $8 \mathrm{ft}$. spread

$16 \mathrm{ft}$. high, $2 \frac{1}{2}$ to $5 \frac{1}{4}$ in. diam., 4 to $8 \mathrm{ft}$. spread

$18 \mathrm{ft}$. high, $3 \frac{1}{4}$ to $5 \mathrm{in}$. diam., 2 to $8 \mathrm{ft}$. spread

$20 \mathrm{ft}$. high, $4 \frac{1}{4}$ to $5 \mathrm{in}$. diam., 5 to $10 \mathrm{ft}$. spread

$24 \mathrm{ft}$. high, $5 \frac{3}{4}$ in. diam., $10 \mathrm{ft}$. spread.

$2 \mathrm{ft}$. high, $6 \frac{1}{4}$ to $6 \frac{3}{4}$ in. diam., 10 to $14 \mathrm{ft}$. spread

Linden, Spectabilis. $T$. tomentosa, var. spectabilis. $8 \mathrm{ft}$. high $10 \mathrm{ft}$. high, $1 \frac{1}{4}$ to $1 \frac{3}{4}$ in. diam...

$12 \mathrm{ft}$. high, 2 to $2 \frac{1}{2}$ in. diam.

$14 \mathrm{ft}$, high, $2 \frac{1}{2}$ to $3 \frac{1}{4}$ in. diam., 6 to $9 \mathrm{ft}$. spread

$16 \mathrm{ft}$. high, $2 \frac{1}{2}$ to $3 \frac{3}{4}$ in. diam., 5 to $9 \mathrm{ft}$. spread

$18 \mathrm{ft}$. high, $3 \frac{1}{2}$ to $4 \frac{1}{2}$ in. diam., 8 to $9 \mathrm{ft}$. spread

$20 \mathrm{ft}$. high, 5 to $6 \mathrm{in}$. diam., 10 to $12 \mathrm{ft}$. spread

Linden, Weeping Silver. T. petiolaris; syn., argentea, var. pendula.

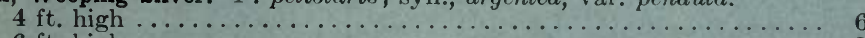

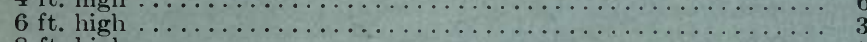

$8 \mathrm{ft}$. high $10 \mathrm{ft}$. high, 2 to 3 in. diam.

$12 \mathrm{ft}$. high, $2 \frac{1}{4}$ in. diam., 4 to $9 \mathrm{ft}$. spread

12 to $18 \mathrm{ft}$. high, 3 to 4 in. diam., 8 to $12 \mathrm{ft}$. spread

Linden, Weeping Silver. 12 to $16 \mathrm{ft}$. high, 4 to 5 in. diam., 8 to $14 \mathrm{ft}$. spread $16 \mathrm{ft}$. high, 6 in. diam., $18 \mathrm{ft}$. spread.

$24 \mathrm{ft}$. high, 6 to $12 \mathrm{in}$. diam., 15 to $18 \mathrm{ft}$. spread

Linden, Small-leaved. T. ulmifolia; syn., microphylla. 6 in. high $8 \mathrm{ft}$. high

$10 \mathrm{ft}$. high, $1 \frac{1}{4}$ to $1 \frac{3}{4}$ in. diam

$10 \mathrm{ft}$. high, 2 to $2 \frac{1}{2} \mathrm{in}$. diam.

$14 \mathrm{ft}$. high, 3 to $4 \frac{1}{2}$ in. diam., 8 to $12 \mathrm{ft}$. spread

$16 \mathrm{ft}$. high, $3 \frac{1}{2}$ to $4 \frac{3}{4}$ in. diam., 8 to $12 \mathrm{ft}$. spread

$18 \mathrm{ft}$. high, 4 to $5 \frac{1}{2} \mathrm{in}$. diam., 8 to $12 \mathrm{ft}$. spread

$20 \mathrm{ft}$. high, 5 to $7 \frac{1}{4}$ in. diam., 10 to $16 \mathrm{ft}$. spread

$22 \mathrm{ft}$. high, 5 to $7 \frac{1}{2}$ in. diam., 7 to $15 \mathrm{ft}$. spread

$24 \mathrm{ft}$. high, $7 \frac{1}{2}$ to 9 in. diam., 12 to $18 \mathrm{ft}$. spread

$30 \mathrm{ft}$. high, $6 \frac{1}{4}$ in. diam., $12 \mathrm{ft}$. spread.

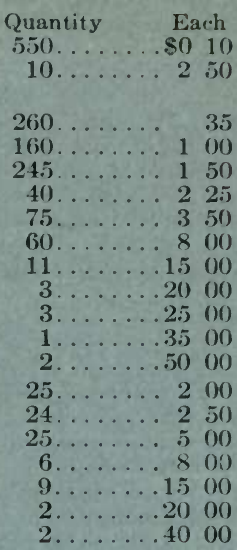

Per 10 Per 100

$\$() \quad 90 \quad \$ 600$

$300 \quad 2500$

$\begin{array}{rcc}9 & 00\end{array}$

$14(00)$

2200

3200

7500

2250

4.500

$60 \ldots \ldots, 75$

$15 \ldots \ldots \ldots 200$

$18 \ldots \ldots \ldots 350$

$3 \ldots \ldots 500$

$20 \ldots \ldots \ldots 1500$

6. . . . 20 00

$1 \ldots \ldots \ldots 3000$

$2 \ldots \ldots 6000$

$170 \ldots \ldots \ldots 150$

$135 \ldots \ldots \ldots 150$

$25 \ldots \ldots 200$

$50 \ldots \ldots \ldots 250$

$32 \ldots \ldots \ldots 1200$

$66 \ldots \ldots 2000$

2000
2500

$\begin{array}{ll}25 & 00 \\ 30 & 00\end{array}$

$6 \ldots \ldots \ldots 4000$
$4 \ldots \ldots \ldots 4500$
$4 \ldots \ldots .5500$

$6 \ldots \ldots \ldots 40$
$4 \ldots \ldots \ldots 4500$
$4 \ldots \ldots 500$

$4 \ldots \ldots 5500$
$1 \ldots \ldots 6000$

Linden, American (Basswood). T. Americana. $8 \mathrm{ft}$. high. $10 \mathrm{ft}$. high, $1 \frac{1}{2}$ to $1 \frac{3}{4}$ in. diam...

$14 \mathrm{ft}$. high, 2 to 3 in. dian., 5 to $9 \mathrm{ft}$. spread

$16 \mathrm{ft}$. high, $3 \frac{1}{4}$ to $4 \frac{1}{4}$ in. diam., 6 to $12 \mathrm{ft}$. spread

$18 \mathrm{ft}$. high, 5 to $6 \frac{1}{2}$ in. diam., 9 to $15 \mathrm{ft}$. spread

$20 \mathrm{ft}$. high, $4 \frac{1}{2}$ to $5 \mathrm{in}$. diam., 8 to $10 \mathrm{ft}$. spread

$20 \mathrm{ft}$. high, $5 \frac{1}{2}$ to $6 \frac{1}{2}$ in. diam., $15 \mathrm{ft}$. spread ...

$22 \mathrm{ft}$. high, $6 \frac{3}{4}$ to 8 in. diam., 12 to $15 \mathrm{ft}$. spread ...

24 to $26 \mathrm{ft}$. high, $6 \frac{3}{4}$ in. diam., $15 \mathrm{ft}$. spread

28 to $30 \mathrm{ft}$. high, $7 \frac{1}{4}$ to $9 \frac{3}{4}$ in. diam., 14 to $28 \mathrm{ft}$. spread

$34 \mathrm{ft}$. high, 11 to 14 in. diam., $24 \mathrm{ft}$. spread

$38 \mathrm{ft}$. high, $14 \mathrm{in}$. diam., $21 \mathrm{ft}$. spread.

Liquidambar (Sweet Gum). Liquidambar styraciflua. $1 \mathrm{ft}$. high $2 \mathrm{ft}$. high

$4 \mathrm{ft}$. high

$6 \mathrm{ft}$. high

75

120

60
6

175

1250

17 50

$22 \quad 50$

9000

15000

22500

27500

1500 10060

$8 \mathrm{ft}$ high $\ldots \ldots \ldots \cdots \cdots \cdots \cdots \cdots$

100

150

400

1500

.1200

1500

2500

.3000

.4000

$7 \ldots \ldots .40$
$1 \ldots \ldots .700$
$1 \ldots \ldots .9500$

$\begin{array}{ll}450 \ldots \ldots \ldots & 15 \\ 750 \ldots \ldots & 25\end{array}$

$250 \ldots \ldots$
$75 \ldots \ldots$

$40 \ldots \ldots \ldots 125$

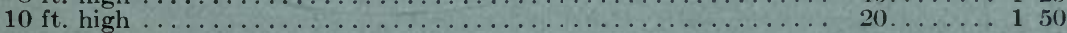

$24 \mathrm{ft}$. high, 8 in. diam., $15 \mathrm{ft}$. spread.

3500

$27 \mathrm{ft}$. high, $101 \mathrm{in}$. diam., $17 \mathrm{ft}$. spread

Liquidambar is reputed to be diffieult to transplant. We anticipate little difficulty with this stock. They make most beautiful and symmetrical trees of the highest elass. We recommend the planting of this small stock in private nurseries and in large landscape plantations. It is sure to be hardy, because from Long Island seed, whereas southern stock planted here we have found to winterkill.

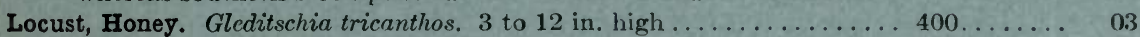

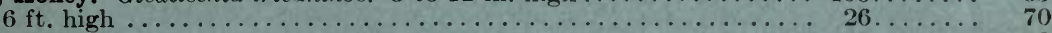

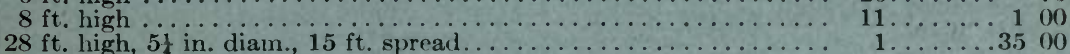

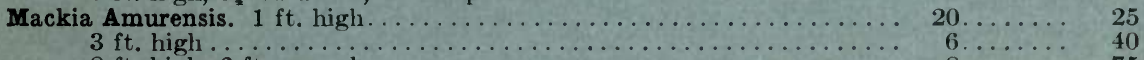
$8 \mathrm{ft}$. high, $6 \mathrm{ft}$. spread
$18 \mathrm{ft}$. high, 5 in. diam., $15 \mathrm{ft}$. spread. $\ldots \ldots \ldots \ldots \ldots \ldots \ldots \ldots \ldots \ldots \ldots \ldots \ldots \ldots$

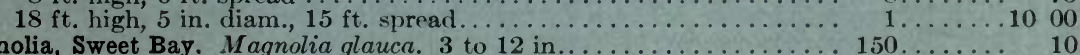

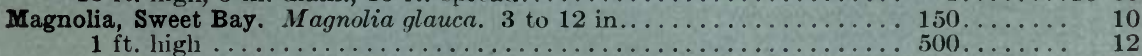

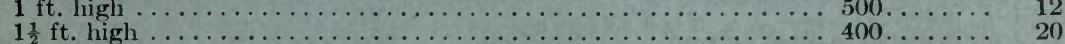

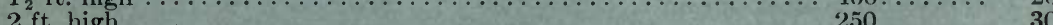

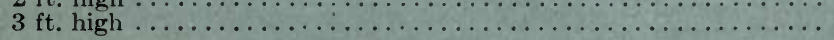

$\ldots$

30

$500 \quad 3500$

$600 \quad 5000$

1000

2000

30 00 
DECIDUOUS TREES, MAGNOLIA to MAPLE.

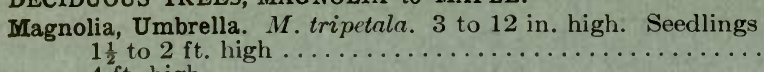

$4 \mathrm{ft}$. high

$8 \mathrm{ft}$. high

$10 \mathrm{ft}$. high, 1 to 2 in. diam., 3 to $6 \mathrm{ft}$. spread

$12 \mathrm{ft}$. high, $1 \frac{1}{2}$ to $2 \frac{1}{4}$. diam., 4 to $6 \mathrm{ft}$. spread

Magnolia tripetala is a striking tree of luxuriant, tropical appearance. The trees, 10 and 12 feet high, are of excellent quality and priced very low, presenting an opportunity that will probably not be duplicated.

Magnolia, Large-leaved. M. macrophylla. 6 to 12 in. high . $1 \mathrm{ft}$. high

$2 \mathrm{ft}$. high

$3 \mathrm{ft}$. high
$4 \mathrm{ft}$. high

$4 \mathrm{ft}$. high $5 \mathrm{ft}$. high

$6 \mathrm{ft}$. high

$8 \mathrm{ft}$. high

$10 \mathrm{ft}$. high, 4 to $6 \mathrm{ft}$. spread

A very rare tree in nurseries. This is a chance to get the largest flower hardy in this climate.

Magnolia Frazerii. $6 \mathrm{ft}$. high

10 to $12 \mathrm{ft}$. high

Magnolia, Cucumber. M. acuminata. 2 to 12 in., seedlings $1 \mathrm{ft}$. high

$2 \mathrm{ft}$. high

$4 \mathrm{ft}$. high

$6 \mathrm{ft}$. high

$8 \mathrm{ft}$. high

$10 \mathrm{ft}$. high, 5 to $6 \mathrm{ft}$. spread

$28 \mathrm{ft}$. high, 9 in diam $16 \mathrm{ft}$.

Magnolia conspicua; syn., Yulan. $2 \mathrm{ft}$. high

$4 \mathrm{ft}$. high

$6 \mathrm{ft}$. high

$8 \mathrm{ft}$. high

$10 \mathrm{ft}$. high, $7 \mathrm{ft}$. spread

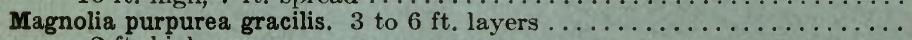
$2 \mathrm{ft}$. high

$4 \mathrm{ft}$. high

$6 \mathrm{ft}$. high

Magnolia Soulangeana. $1 \frac{1}{2} \mathrm{ft}$. high

$2 \mathrm{ft}$. high
$3 \mathrm{ft}$. high

$5 \mathrm{ft}$. high

$6 \mathrm{ft}$. high

$7 \mathrm{ft}$. high

10 to $13 \mathrm{ft}$. high

Magnolia speciosa. $3 \mathrm{ft}$. high

$9 \mathrm{ft}$. high

Magnolia Lennei. $3 \mathrm{ft}$. high

$5 \mathrm{ft}$. high

$6 \mathrm{ft}$. high

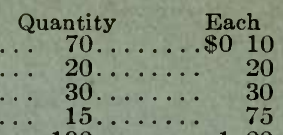

$100 \ldots \ldots \ldots 100 \quad 850$

$55 \ldots \ldots \ldots 150 \quad 1250$

Per 10

$\$ 075$

150

250

Per 100

$\$ 600$

6500

10000

$\begin{array}{rrrrr}30 \ldots \ldots \ldots & 30 & 2 & 50 \\ 100 \ldots \ldots & 50 & 4 & 50 \\ 70 \ldots \ldots & 1 & 00 & 7 & 50 \\ 65 \ldots \ldots & 1 & 50 & 12 & 50 \\ 20 \ldots \ldots & 2 & 00 & 17 & 50 \\ 30 \ldots \ldots & 2 & 50 & 22 & 50 \\ 35 \ldots \ldots & 3 & 00 & 25 & 00 \\ 13 \ldots \ldots & 4 & 00 & & \end{array}$

4000

750

1250

1750

2500

$3 \ldots \ldots \ldots 100$

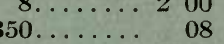

$45 \ldots \ldots \ldots \quad 15$

$100 \ldots \ldots .40$

75

500

$\begin{array}{lll}3 & 00\end{array}$

2500

$20 \ldots \ldots \ldots 100$

$8 \ldots \ldots \ldots 150$

$4 \ldots \ldots \ldots 400$

$1 \ldots \ldots .5000$

$50 \ldots \ldots \ldots 175$

$13 \ldots \ldots \ldots 350$

$2 \ldots \ldots 6600$

$2 \ldots \ldots \ldots 1000$

$1 \ldots \ldots \ldots 1500$

$100 \ldots \ldots \ldots 25$

$20 \ldots \ldots \ldots$
$10 \ldots \ldots$

$10 \ldots \ldots \ldots$
$5 \ldots \ldots \ldots 100$

$\begin{array}{ll}2 & 25 \\ 3 & 00\end{array}$

2000

500

$30 \ldots \ldots \ldots 75$

$40 \ldots \ldots \ldots 85$

$50 \ldots \ldots \ldots 100$

600

750

850

$8 \ldots \ldots \ldots$
$6 \ldots \ldots$

$6 \ldots \ldots$
$5 \ldots \ldots$

$4 \ldots \ldots \ldots 1200$

$2 \ldots \ldots \ldots 125$

$2 \ldots \ldots \ldots 1200$

$15 \ldots \ldots \ldots 250$

$7 \ldots \ldots \ldots 400$

$11 \ldots \ldots \ldots 500$

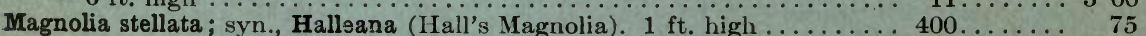

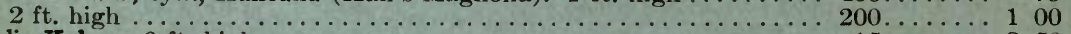

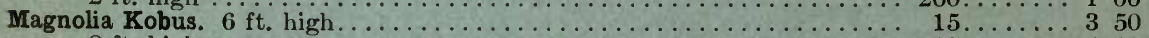

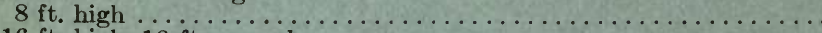

$16 \mathrm{ft}$. high, $10 \mathrm{ft}$. spread

Magnolia hypoleuca. $2 \mathrm{ft}$. high.

$4 \mathrm{ft}$. high

$6 \mathrm{ft}$. high

$8 \mathrm{ft}$. high

$10 \mathrm{ft}$. high, $1 \frac{1}{4}$ to $1 \frac{1}{2}$ in. diam

$12 \mathrm{ft}$. high, $1 \frac{1}{4}$ to $1 \frac{3}{4}$ in. diam.

$20 \mathrm{ft}$. high, $3 \frac{1}{2}$ in. diam.

In the Arboretum of the late Chas. A. Dana, at Glen Cove, there is a noble specimen of this 30 feet broad. The flowers are giant cups of cream and crimson, 9 inches wide.

Magnolia parviflora. $4 \mathrm{ft}$. high

$15 \ldots \ldots 400$

$1 \ldots \ldots 2000$

$7 \ldots \ldots \ldots 100$

$4 \ldots \ldots \ldots 200$

$5 \ldots \ldots \ldots 250$

$6 \ldots \ldots 300$

$14 \ldots \ldots .400$

$4 \ldots \ldots \ldots 500$

$1 \ldots \ldots \ldots 1500$

700

$\begin{array}{lll}9 & 00\end{array}$

3000

3500

3000

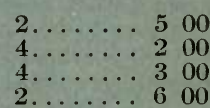

$5 \mathrm{ft}$. high

Maple, Norway. Acer platanoides. $8 \mathrm{ft}$. high

$10 \mathrm{ft}$. high, 1 to $1 \frac{3}{4} \mathrm{in}$. diam..

$12 \mathrm{ft}$. high, $1 \frac{1}{4}$ to $1 \frac{3}{4}$ in. diam...

14 to $18 \mathrm{ft}$. high, $1 \frac{1}{2}$ in. diam...

14 to $18 \mathrm{ft}$. high, 2 in. diam...

14 to $18 \mathrm{ft}$. high, 3 in. diam..

14 to $18 \mathrm{ft}$. high, $3 \frac{1}{2}$ in. diam...

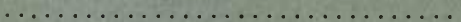

20 to $24 \mathrm{ft}$. high, 4 in. diam., 6 to $10 \mathrm{ft}$. spread

20 to $24 \mathrm{ft}$. high, $5 \mathrm{in}$. diam., 10 to $12 \mathrm{ft}$. spread

20 to $24 \mathrm{ft}$. high, 6 in. diam., 10 to $12 \mathrm{ft}$. spread
2....... 75

$500 \ldots \ldots \ldots 8.65$

$300 \ldots \ldots 100$

$125 \ldots \ldots \ldots 135$

$75 \ldots \ldots \ldots 200$

$50 \ldots \ldots 300$

$50 \ldots \ldots \ldots 500$

$50 \ldots \ldots 700$

$35 \ldots \ldots 8800$

$200 \ldots \ldots \ldots 1500$

$30 \ldots \ldots 3000$
$200 \ldots \ldots 2000$

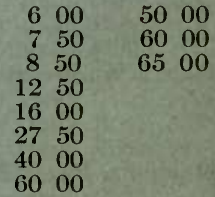

$14000 \quad 1,000 \quad 00$ $18000 \quad 1,60000$ 
DECIDUOUS TREES, MAPLE.

Maple, Norway. 20 to $24 \mathrm{ft}$. high, 63 in. diam., 10 to $12 \mathrm{ft}$. spread 20 to $21 \mathrm{ft}$. high, $7 \frac{3}{4}$ in. diam.

26 to $30 \mathrm{ft}$. high, $5 \mathrm{in}$. diam., 10 to $14 \mathrm{ft}$. spread

26 to $30 \mathrm{ft}$. high, 6 in. diam., 12 to $15 \mathrm{ft}$. spread

26 to $30 \mathrm{ft}$. high, 7 in. diam., 12 to $15 \mathrm{ft}$. spread

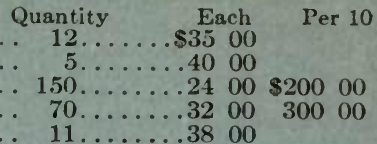

The price of these 5- to 8-inch diameter Norway Maples at $\$ 15$ to $\$ 38$ is low, considering the fifteen to eighteen years it has taken to grow them, and the wide area given each tree- 225 square feet. They are low in price according to the cost of cultivating, manuring, pruning and transplanting them. They save eight to

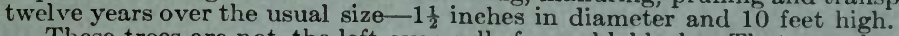

These trees are not the left-over culls from old blocks. That was the old system of growing extra-sized trees. Under those conditions, the trees were frequently erooked, with unsymmetrical tops and long,

These trees have been especially grown to make transplanting suecessful. They have abundant fibrous roots which, by the methods of digging of our invention, are carefully preserved. Such trees grow vigorously from the start and the smaller trees do not quickly overtake them, - a statement formerly made to discourage planting large trees. Page 21 shows how they are grown. They are numbered specimens, pruned to exactly uniform sizes; that is, we can supply an avenue 20 feet in height, 10 feet in spread. These trees are often used by architects in formal plantings, to be trimmed to arch a walk. Results which in France would take ten years to produce, can be produced here immediately.

Maple Schwedler's Purple Norway. A. platanoides, var. Schwedleri. $6 \mathrm{ft}$. high ..........................

$8 \mathrm{ft}$. high .......

$10 \mathrm{ft}$. high, 1 to $1 \frac{3}{4} \mathrm{in}$. diam.

$18 \mathrm{ft}$. high, $4 \frac{1}{2}$ in. diam.

$20 \mathrm{ft}$. high, 5 in. diam.

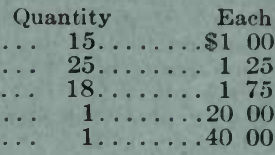

Maple, Reitenbach's Purple Norway. A. platanoides, var. Reitenbachi. $6 \mathrm{ft}$. high 16 to $18 \mathrm{ft}$ high, 4 in. diam., $8 \mathrm{ft}$. spread

$24 \mathrm{ft}$. high, 8 in. diam., $17 \mathrm{ft}$. spread.

Maple, Sugar, Rock or Hard A. saccharum; svn., A. saccharinum. $8 \mathrm{ft}$. high $\ldots \ldots \ldots \ldots \ldots$

$10 \mathrm{ft}$. high, 1 to $1 \frac{1}{4}$ in. diam..

$16 \mathrm{ft}$. high, $1 \frac{3}{4}$ to $2 \frac{3}{4}$ in. diam...

$18 \mathrm{ft}$. high, 2 to $3 \mathrm{in}$. diam..

$18 \mathrm{ft}$. high, 3 to 4 in. diam.....

20 to $24 \mathrm{ft}$. high, 2 in. diam...

20 to $24 \mathrm{ft}$. high, $3 \mathrm{in}$. diam.

$24 \mathrm{ft}$. high, 3 to $4 \frac{1}{2}$ in. diam.

$26 \mathrm{ft}$. high, 3 to $4 \frac{3}{4}$ in. diam., 4 to $10 \mathrm{ft}$. spread

$28 \mathrm{ft}$. high, $4 \frac{1}{2}$ to $5 \frac{3}{4} \mathrm{in}$. diam., 5 to $12 \mathrm{ft}$. spread

$30 \mathrm{ft}$. high, $5 \frac{1}{4}$ to $6 \frac{3}{4}$ in. diam., $12 \mathrm{ft}$. spread ........

Maple, Sycamore. A. pseudo-platanus.

$10 \mathrm{ft}$. high, 1 to $1 \frac{3}{4}$ in. diam., 3 to $5 \mathrm{ft}$. spread

$12 \mathrm{ft}$. high, $1 \frac{1}{4}$ to $2 \frac{1}{2}$ in. diam., 3 to $6 \mathrm{ft}$. spread

$14 \mathrm{ft}$. high, $1 \frac{1}{2}$ to $2 \frac{3}{4}$ in. diam., 4 to $8 \mathrm{ft}$. spread

$16 \mathrm{ft}$. high, 2 to $3 \mathrm{in}$. diam., 4 to $10 \mathrm{ft}$. spread. .

$20 \mathrm{ft}$. higl, 3 to $3 \frac{3}{4}$ in. diam., 6 to $8 \mathrm{ft}$. spread

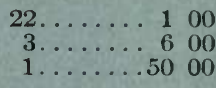

$\$ 800$

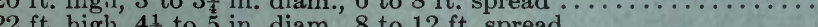

$24 \mathrm{ft}$. high, $4 \frac{1}{2}$ to $6 \mathrm{in}$. diam., 8 to $15 \mathrm{ft}$. spread

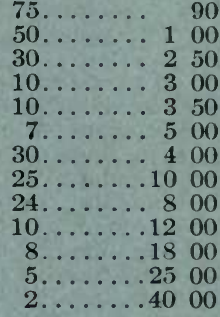

700

850

2000

2500

3000

3500

9000

7000

10000

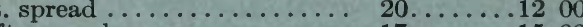

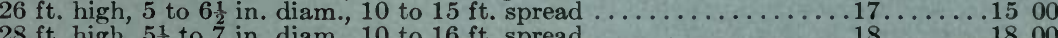

$30 \mathrm{ft}$. high, $5 \frac{1}{2}$ to $6 \frac{1}{2}$ in. diam., 10 to $16 \mathrm{ft}$. spread . . . . . . . . . . .

$25 \ldots \ldots .85 \quad 700$

$40 \ldots \ldots .100 \quad$ S 00

$26 \ldots \ldots \ldots 150 \quad 1250$

$15 \ldots \ldots \ldots 175 \quad 1500$

$5 \ldots \ldots .300$

$10 . \ldots . . .800$

7000

10000

12500

15000

These Sycamore Maples are darker in foliage than the Norway, perfectly straight and symmetrical. They will make magnificent formal avenues and are excellent trees at the seaside for their thick, heavy foliage which withstands the salt spray. The prices are especially low for trees of this size and quality, as we wish to reduce our stock, the trees being in blocks which will crowd if they remain two years longer.

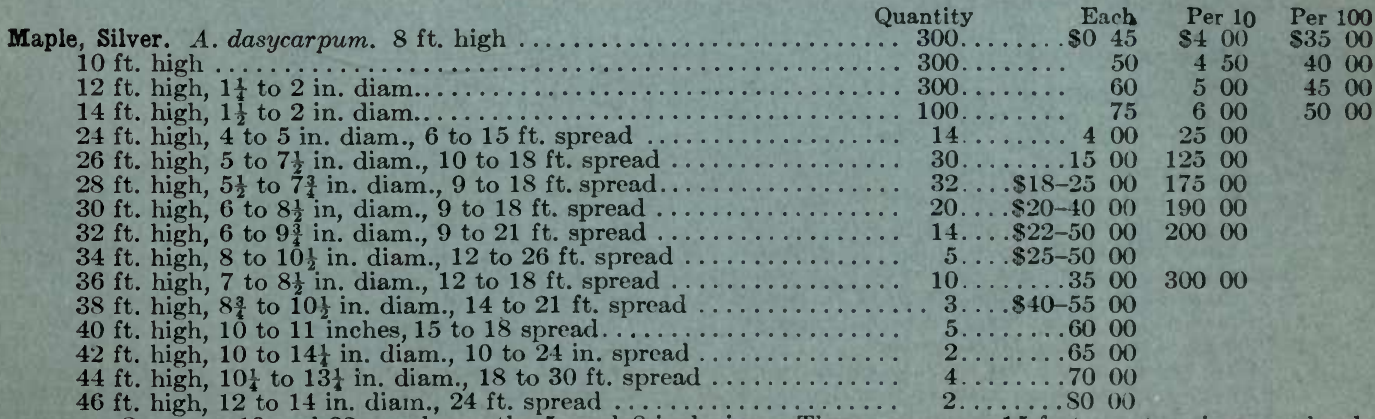

On pages 19 and 22 are shown the 5 - and 8 -inch sizes. These are grown 15 feet apart, as in an orchard, and have been pruned to symmetrical form. With the Catalpas, these Maples give the largest amount of sliade for the cost, and save the most years of waiting. It is not the best tree for all purposes, but it is a good tree, and the stock we offer is in the best possible condition for vigorous growth. They are easily handled on our tree-movers, and the price to deliver and plant is low. Page 27 shows the result of planting a tree 10 inches in diameter to shade a new house on a bare lot.

For street planting on real estate subdivisions, trees 10 and 12 feet high are a good investment. They transplant readily and grow rapidly the first year, especially if the ground is mulched with 3 inches of manure. 


\section{DECIDUOUS TREES, MAPLE to OAK.}

Maple, Wier's Weeping Silver. A. saccharinum, var. Wierii.

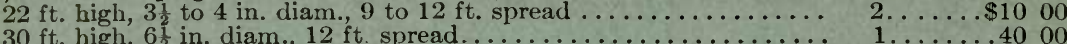

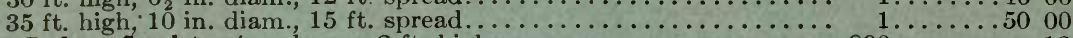

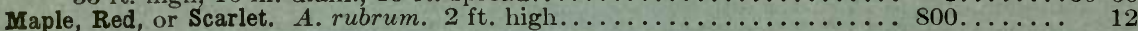

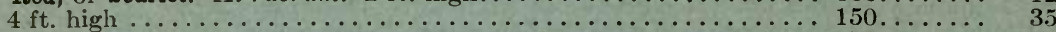

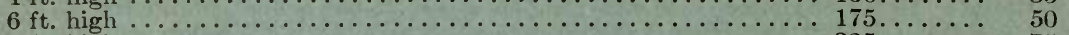

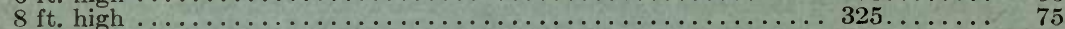

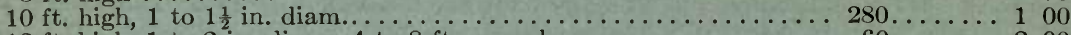

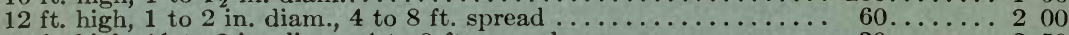

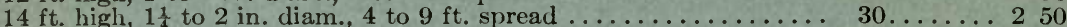

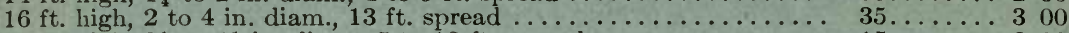

$18 \mathrm{ft}$. high, $3 \frac{1}{4}$ to $4 \frac{1}{2}$ in. diam., 5 to $10 \mathrm{ft}$. spread $\ldots \ldots \ldots \ldots \ldots \ldots \ldots 1 . \ldots \ldots \ldots$

$20 \mathrm{ft}$. high, 4 to $6 \frac{1}{\mathrm{in}}$. diam., 8 to $10 \mathrm{ft}$. spread $\ldots \ldots \ldots \ldots \ldots \ldots \ldots$

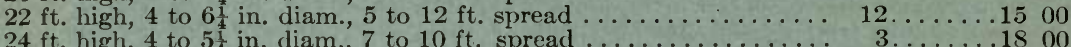

Maple, Ash-leaved (Box Elder). A. Negundo.

$30 \mathrm{ft}$. high, $6 \frac{1}{2}$ in. diam., $12 \mathrm{ft}$. spread

$32 \mathrm{ft}$. high, 6 to $9 \frac{1}{2}$ in. diam., $14 \mathrm{ft}$. spread

$36 \mathrm{ft}$. high, $7 \mathrm{in}$. diam., $12 \mathrm{ft}$. spread.

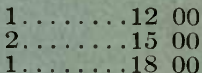

Mulberry, Tea's Weeping. Morus alba, var. Tatarica pendula.

$6 \mathrm{ft}$. high, $5 \mathrm{ft}$. spread

$9 \mathrm{ft}$. high, $7 \frac{1}{2}$ in. diam., 9 to $14 \mathrm{ft}$. spread. Trained as summer

houses. Ten years old $\ldots \ldots \ldots \ldots \ldots \ldots \ldots \ldots \ldots \ldots \ldots$ illustrated on page 22.

$10 \ldots \ldots \ldots$

$3 \ldots \ldots 2000$

These three larger plants at $\$ 20$ are illustrated on page 22 .
Quercus palustris.

Oak, Pin. Quercus palustris.
2 to 4 in. high, 1 -yr. seedlings. . Per $1,000, \$ 9$; per $10,000, \$ 40 \ldots 10,000 \ldots \ldots \ldots 02$

1 to $2 \mathrm{ft}$. high

$2 \mathrm{ft}$. high

$3 \mathrm{ft}$. high

$4 \mathrm{ft}$. high

Per $1,000, \$ 100 \ldots 2,000 \ldots \ldots \ldots . \quad 10$

$5 \mathrm{ft}$. high

Per $1,000, \$ 150 \ldots 1,300$

$6 \mathrm{ft}$. high

Per $1,000, \$ 250 \ldots 3,000$

, $000 \ldots \ldots \ldots \quad 35$

$8 \mathrm{ft}$. high

$10 \mathrm{ft}$. high, $1 \frac{1}{4}$ to $1 \frac{3}{4}$ in. diam., 4 to $9 \mathrm{ft}$. spread

$12 \mathrm{ft}$. high, $1 \frac{1}{2}$ to $2 \mathrm{in}$. diam., 3 to $9 \mathrm{ft}$. spread

$100 \ldots \ldots \ldots 100$

$14 \mathrm{ft}$, high, 2 to 3 in. diam., 5 to $8 \mathrm{ft}$. spread

$16 \mathrm{ft}$. high, 2 to $3 \frac{1}{2}$ in. diam., 5 to $9 \mathrm{ft}$. spread

$18 \mathrm{ft}$. high, $2 \frac{3}{4}$ to $4 \mathrm{in}$. diam., 6 to $14 \mathrm{ft}$. spread

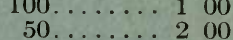

$70 \ldots \ldots \ldots 25$

$15 \ldots \ldots \ldots 300$

$71 \ldots \ldots .600$

$20 \mathrm{ft}$. high, 4 to $5 \mathrm{in}$. diam., 6 to $12 \mathrm{ft}$. spread

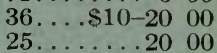

$22 \mathrm{ft}$. high, 5 to $7 \mathrm{in}$. diam., 10 to $15 \mathrm{ft}$. spread

$25 \ldots \ldots \ldots 2000$

$24 \mathrm{ft}$. high, $5 \frac{1}{2}$ to $7 \mathrm{in}$. diam., 9 to $15 \mathrm{ft}$. spread

$12 \ldots \ldots \ldots 3000$

$26 \mathrm{ft}$. high, $5 \frac{1}{2}$ to $6 \mathrm{in}$. diam., 6 to $14 \mathrm{ft}$. spread

$26 \mathrm{ft}$. high, 9 in. diam., 6 to $14 \mathrm{ft}$. spread

$28 \mathrm{ft}$. high, 6 to 8 in. diam., 12 to $16 \mathrm{ft}$. spread

23.

$8 \ldots \ldots$

$8 \ldots \ldots$

$5 \ldots \ldots \ldots$

$32 \mathrm{ft}$. high, 7 to 9 in. diam., 12 to $20 \mathrm{ft}$. spread

$32 \mathrm{ft}$. high, 11 to $15 \mathrm{in}$. diam., 15 to $24 \mathrm{ft}$. spread

$\begin{array}{r}14 \ldots \ldots \ldots \\ 4 \ldots \ldots \ldots \\ 2 \ldots \ldots \\ 5 \ldots \ldots\end{array} \mid$ Price on selection

$\$ 100 \quad \$ 900$

$300 \quad 2500$

$\begin{array}{llll}4 & 50 & 3500\end{array}$

$\begin{array}{llll}700 & 6000\end{array}$

$9 \begin{array}{llll}90 & \text { SO } & 00\end{array}$

1750

2750

5000

$36 \mathrm{ft}$. high, 10 to $14 \mathrm{in}$. diam., 18 to $24 \mathrm{ft}$. spread . . . . . . . . . . .

$38 \mathrm{ft}$. high, $6 \frac{3}{4}$ to 93 in. diam., 14 to $16 \mathrm{ft}$. spread

$40 \mathrm{ft}$. high, $10 \frac{3}{4}$ to $17 \mathrm{in}$. diam., 16 to $24 \mathrm{ft}$. spread

We believe ours to be the only stoek of large Pin Oaks in any nursery. They are valuable for immediate lawn planting, as illustrated on page 23,24, 25 and 27 . One fortunate things about the Pin Oak is that its long, flexible branches can be tied down to go under trolley wires. The roots are tough and flexible, and, therefore, large trees can be earried aeross ferries or through narrow streets with ease and economy. A number of these larger Pin Oaks have been trimmed to uniform sizes, so that they are valuable for avenue planting or in matched pairs for entrances.

The little trees at less than one cent eaeh are worth planting in private nurseries or in extensive landscape planting. The trees at $\$ 20$ per 100,3 feet high, should be used freely in mixture with other shrubs and trees because they will quickly produce good resu'ts at a low cost.

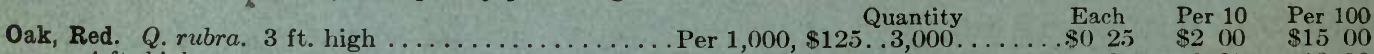

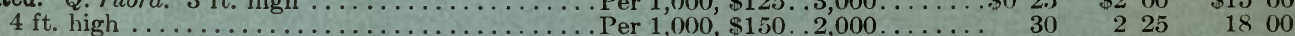

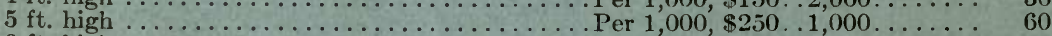

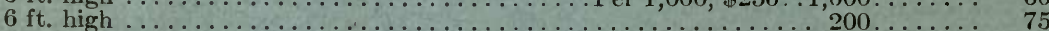

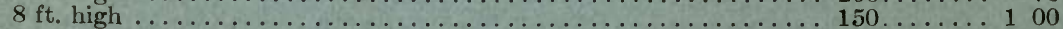

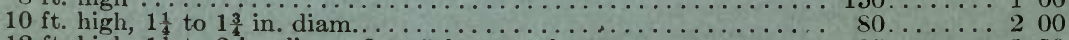

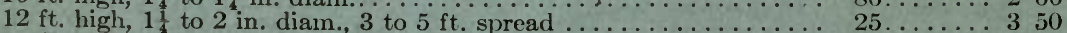

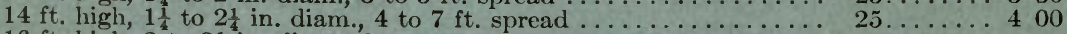

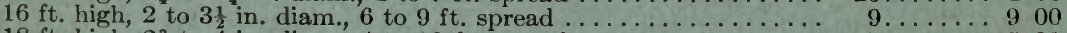
$18 \mathrm{ft}$. high, $2 \frac{3}{4}$ to 4 in. diam., 4 to $10 \mathrm{ft}$. spread $\ldots \ldots \ldots \ldots \ldots \ldots \ldots \ldots$

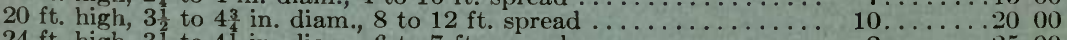

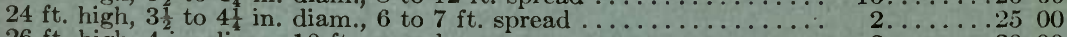

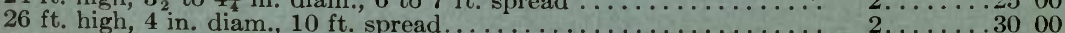

Many object to the eost of Oaks when they are as large as the usual size of Maple, Elm and Poplar-10 and 14 feet. Plant these little ones and you will find that they make as rapid annual growth as the Norway and Sugar Maples. There should be hundreds of miles of Long Island roads shaded with native Oaks grown from Long Island seed. Ours is the only supply, and it is a very cheap one.

Oak scarlet. $\ldots$.
$1 \mathrm{ft}$.
Quantity
Each
$2 \mathrm{ft}$. hig
$250 \ldots \ldots 20$
$3 \mathrm{ft}$. high
$325 \ldots \ldots$
$4 \mathrm{ft}$. high
$40 \ldots \ldots \ldots 60$
$6 \mathrm{ft}$. high
$35 \ldots \ldots \ldots 100$
$30 \ldots \ldots 125$
Per 10
$\$ 040$
180
280
500
9
9
1000

Per 100

$\$ 300$

1500

2500 
DECIDUOUS TREES, OAK to PAULOWNIA.

Oak, Scarlet. $8 \mathrm{ft}$. high

$10 \mathrm{ft}$. high, $1 \frac{1}{4}$ to $1 \frac{1}{2}$ in. diam.

$14 \mathrm{ft}$. high, $1 \frac{1}{2}$ to $3 \frac{1}{2}$ in. diam., 4 to $8 \mathrm{ft}$. spread

$16 \mathrm{ft}$. high, $2 \frac{1}{2}$ to $3 \mathrm{in}$. diam., 6 to $8 \mathrm{ft}$. spread .

$20 \mathrm{ft}$. high, $3 \frac{3}{4}$ to $5 \frac{1}{4}$ in. diam., 8 to $12 \mathrm{ft}$. spread

$24 \mathrm{ft}$. high, $4 \frac{1}{4}$ to 6 in. diam., $9 \mathrm{ft}$. spread

$26 \mathrm{ft}$. high, $5 \frac{1}{2}$ to 6 in. diam., 10 to $12 \mathrm{ft}$. spread

Oak, Black. $Q$. velutina; syn., $Q$. tinctoria. $1 \mathrm{ft}$. high 2 ft. high

$3 \mathrm{ft}$. high

$4 \mathrm{ft}$. high

$8 \mathrm{ft}$. high

$18 \mathrm{ft}$. high, 4 in. diam., $8 \mathrm{ft}$. spread.

Oak, Post. Q. obtusiloba; syn., Q. stellata.

$1 \frac{1}{2} \mathrm{ft}$. high

$2 \mathrm{ft}$. high

$3 \mathrm{ft}$. high

Oak, white. Q. alba. $1 \mathrm{ft}$. high

$2 \mathrm{ft}$. high $3 \mathrm{ft}$. high

$3 \mathrm{ft}$. high

$5 \mathrm{ft}$. high

$6 \mathrm{ft}$. high

$16 \mathrm{ft}$. high, $3 \frac{1}{2}$ in. diam., $6 \mathrm{ft}$. spread
Quantity

Each

$4 \ldots \ldots . \$ 200$
$10 \ldots \ldots .400$

$13 \ldots \ldots 8800$

$5 \ldots \ldots 1200$

$4 \ldots \ldots \ldots 2000$

$9 \ldots \ldots 2200$

$3 \ldots \ldots 2500$

$3 \ldots \ldots 3000$

$\begin{array}{ll}300 \ldots \ldots & 20 \\ 100 \ldots \ldots & 30\end{array}$

$140 \ldots \ldots .40$

$140 \ldots \ldots, 60$

$3 \ldots \ldots \ldots 150$

$1 \ldots \ldots \ldots 1500$

$1 \ldots \ldots .4500$

$\$ 150$

250

350

500

900

2000

3000

4500

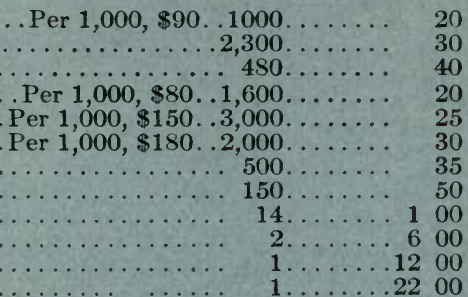

150

250

300

150

200

250

300

450

900

$\begin{array}{ll}6 & 00\end{array}$

$\begin{array}{rl}12 & 00 \\ 22 & 00\end{array}$

2500

1000

$\begin{array}{ll}18 & 00 \\ 20 & 00\end{array}$

2500

4000

A large part of Long Island is underlaid by sand and gravel, giving excessive drainage. The following Oaks thrive well under such conditions: White, Chestnut, Post, Black, Scarlet and Black Jack Oak. The economical thing to do is to plant them in large quantities when of small size. Our trees 1 to 5 feet high are transplanted, and were root-pruned last year.

Oak, Chestnut. Q. prinos. $3 \mathrm{ft}$. high

$4 \mathrm{ft}$. high

$5 \mathrm{ft}$. high

$10 \mathrm{ft}$. high, $1 \frac{1}{4}$ in. diam.

Oak, Chestnut, Dwarf. Q. prinoides. $1 \mathrm{ft}$. high

Oak, Swamp White. Q. bicolor. $1 \mathrm{ft}$. high

$2 \mathrm{ft}$. high

$6 \mathrm{ft}$. high

$10 \mathrm{ft}$. high, 2 to $2 \frac{1}{\mathrm{in}}$. diam., 2 to $4 \mathrm{ft}$. spread

$14 \mathrm{ft}$. high, 2 to $2 \frac{1}{2}$ in. diam., 4 to $6 \mathrm{ft}$. spread

$16 \mathrm{ft}$. high, $2 \frac{1}{3}$ to $3 \frac{1}{2}$ in. diam., 4 to $6 \mathrm{ft}$. spread

$18 \mathrm{ft}$. high, $3 \frac{1}{2}$ to 6 in. diam., 6 to $9 \mathrm{ft}$. spread

$20 \mathrm{ft}$. high, $4 \mathrm{in}$. diam., $8 \mathrm{ft}$. spread.

$26 \mathrm{ft}$. high, $6 \frac{1}{4}$ in. diam., $10 \mathrm{ft}$. spread

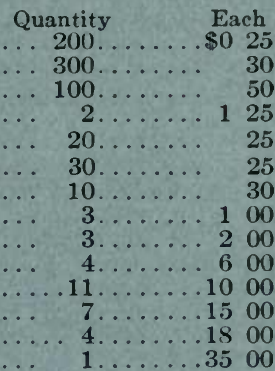

Oak, Mossy Cup, or Bur. Q. macrocarpa.

9 to 12 in. high, 2-yr. transplanted

$1 \mathrm{ft}$. high

$2 \mathrm{ft}$. high

$130 \ldots \ldots 10$

$3 \mathrm{ft}$. high

300

450

$4 \mathrm{ft}$. high

$6 \mathrm{ft}$. high

$10 \mathrm{ft}$. high, $1 \frac{1}{4}$ to $2 \frac{1}{4}$ in. diam., $3 \mathrm{ft}$. spread

$16 \mathrm{ft}$. high, $3 \frac{1}{2}$ to 6 in. diam., 6 to $9 \mathrm{ft}$. spread

$22 \mathrm{ft}$. high, 6 in. diam., $9 \mathrm{ft}$. spread.

$28 \mathrm{ft}$. high, $6 \frac{1}{4}$ to $7 \frac{1}{2} \mathrm{in}$. diam., 10 to $15 \mathrm{ft}$. spread

$30 \mathrm{ft}$. high, $9 \frac{1}{2}$ in. diam., $25 \mathrm{ft}$. spread.

Oak, Scrub. Q. ilicifolia. 6 to $12 \mathrm{in.} \mathrm{high}$

$1 \mathrm{ft}$. high

Oak, Laurel-leaved. $Q$. imbricaria. 3 to $4 \mathrm{ft}$. high, seedlings

$1 \mathrm{ft}$., transplanted.

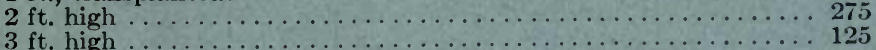

Oak, Black Jack. Q. Marilandica; syn., Q. nigta, $Q$. ferruginea

2 to 4 in. high, 1 -yr. seedlings ................ $1,000, \$ 10 \ldots 1,500 \ldots \ldots$

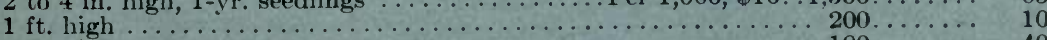

$3 \mathrm{ft}$. high

Oak, Willow. Q. Phellos.

10 to $14 \mathrm{ft}$. high, $1 \frac{1}{4}$ to $4 \frac{1}{3} \mathrm{in}$. diam., 4 to $8 \mathrm{ft}$. spread $\ldots \ldots \ldots \ldots \ldots 14 \ldots \ldots \ldots$

Oak, English, or Royal. $Q$. pedunculata. $6 \mathrm{ft}$. high $\ldots \ldots \ldots \ldots \ldots \ldots \ldots 75 \ldots \ldots \ldots$

$8 \mathrm{ft}$. high

$10 \mathrm{ft}$. high, $1 \frac{1}{4}$ to $2 \frac{1}{2}$ in. diam., 4 to $6 \mathrm{ft}$. spread

$14 \mathrm{ft}$. high, $1 \frac{3}{4}$ to 3 in. diam., 6 to $8 \mathrm{ft}$. spread

$16 \mathrm{ft}$. high, $1 \frac{3}{4}$ to $3 \frac{1}{2}$ in. diam., 6 to $8 \mathrm{ft}$. spread

$18 \mathrm{ft}$. high, $2 \frac{3}{4}$ to $3 \frac{3}{3}$ in. diam., 6 to $12 \mathrm{ft}$. spread

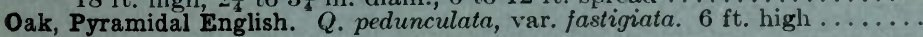

$8 \mathrm{ft}$. high

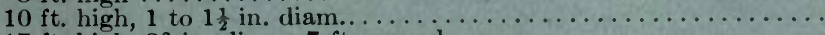

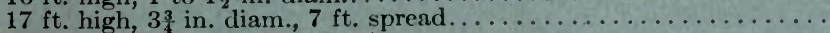

Paulownia imperialis (Empress Tree).

$26 \mathrm{ft}$. high, 11 to 11 in. diam., 12 to $15 \mathrm{ft}$. spread.

$30 \mathrm{ft}$. high, $15 \frac{1}{2} \mathrm{in}$. diam., $27 \mathrm{ft}$. spread.

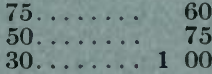

$30 \ldots \ldots \ldots 150$

$30 \ldots \ldots 200$

$17 \ldots \ldots \ldots 250$

$3 \ldots \ldots 200$

$6 \ldots \ldots \ldots 300$

$5 \ldots \ldots .400$

$2 \ldots \ldots \ldots 1500$

90

110

150

175

800

1000

1200

$225 \quad 2000$

1500

200

250

$2 \ldots \ldots .2500$

$1 \ldots \ldots 10000$ 
DECIDUOUS TREES, PAW-PAW to YELLOW-WOOD.

Paw-Paw. Asimina triloba. $6 \mathrm{ft}$. high, $4 \mathrm{ft}$. spread .

Persimmon. Diospyros Virginiana. $2 \mathrm{ft}$. high $8 \mathrm{ft}$. high ...................................

Phellodendron Amurense (Chinese C
$10 \mathrm{ft}$. high, $1 \frac{1}{4}$ to $2 \frac{3}{2}$ in. diam.

$12 \mathrm{ft}$. high, 2 to 3 in. diam., 5 to $9 \mathrm{ft}$. spread

$14 \mathrm{ft}$. high, $2 \frac{1}{4}$ to $3 \frac{1}{2}$ in. diam., 5 to $8 \mathrm{ft}$. spread

$16 \mathrm{ft}$. high, $2 \frac{1}{2}$ to 4 in. diam., 6 to $12 \mathrm{ft}$. spread ...

These Cork trees are especially cheap for mass planting because they are very vigorous and make a dense growth the first year. We put the price low because we wish to clear the block where they are growing.

Plane Tree. Platanus orientalis. $12 \mathrm{ft}$. high, 2 to $2 \frac{3}{4}$ in, diam...

$14 \mathrm{ft}$. high, $1 \frac{1}{2}$ to 3 in. diam., 4 to $12 \mathrm{ft}$. spread

$16 \mathrm{ft}$. high, $1 \frac{3}{4}$ to $3 \mathrm{in}$. diam., 4 to $8 \mathrm{ft}$. spread

$18 \mathrm{ft}$. high, $2 \frac{1}{2}$ to $3 \frac{1}{4}$ in. diam., 6 to $9 \mathrm{ft}$. spread

$20 \mathrm{ft}$. high, $3 \frac{1}{4}$ to $3 \frac{3}{4}$ in. diam., 6 to $10 \mathrm{ft}$. spread

24 to $28 \mathrm{ft}$. high, $5 \frac{1}{2}$ to $6 \frac{3}{4}$ in. dian., 10 to $14 \mathrm{ft}$. spread

Poplar, Carolina. Populus deltoides, var. Carolinensis.

$16 \mathrm{ft}$. high, $2 \frac{1}{2}$ in. diam., $5 \mathrm{ft}$. spread.

$20 \mathrm{ft}$. high, $2 \frac{3}{4} \mathrm{in}$. diam., $6 \mathrm{ft}$. spread.

30 to $32 \mathrm{ft}$. high, 7 to $8 \mathrm{in}$. dia n., 10 to $14 \mathrm{ft}$. spread

Poplar, Japanese. P. suaveolens. $8 \mathrm{ft}$. high.

$10 \mathrm{ft}$. high

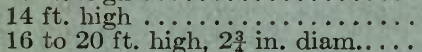

$20 \mathrm{ft}$. high, 2 to $3 \frac{1}{4}$ in. diam.

34 to $40 \mathrm{ft}$. high, 8 to $9 \frac{1}{4}$ in. diam., 12 to $21 \mathrm{ft}$. spread

38 to $44 \mathrm{ft}$. high, 12 to $13 \frac{1}{2} \mathrm{in}$. diam., 20 to $24 \mathrm{ft}$. spread

40 to $44 \mathrm{ft}$. high, 10 to $11 \frac{1}{2}$ in. diam., 14 to $20 \mathrm{ft}$. spread

$40 \mathrm{ft}$. high, 14 to $15 \mathrm{in}$. diam., 27 to $32 \mathrm{ft}$. spread

These large Poplars always attract favorable comment in our Nursery because they go into foliage two weeks before most others. They also hold their foliage until late in autumn, whereas the Carolina Poplar in this region becomes rusty after July.

Poplar, Lombardy. P. nigra, var. Italica; syn., P. fastigiata. $8 \mathrm{ft}$. high . $10 \mathrm{ft}$. high

$18 \mathrm{ft}$. high

Poplar, Balsam. $P$. balsamifera. $4 \mathrm{ft}$. high

$6 \mathrm{ft}$. high

16 to $20 \mathrm{ft}$. high, $2 \frac{1}{2}$ to $3 \frac{3}{4}$ in. diam., 5 to $7 \mathrm{ft}$. spread

$20 \mathrm{ft}$. high, 3 to $3 \frac{3}{4}$ in. diam., 5 to $8 \mathrm{ft}$. spread. .

$28 \mathrm{ft}$. high, $6 \frac{1}{2} \mathrm{in}$. diam., $12 \mathrm{ft}$. $\mathrm{s}$
Poplar, Bollis. P. alba, var. Bolleana.

24 to $28 \mathrm{ft}$. high, 3 to $5 \mathrm{in}$. diam., $6 \mathrm{ft}$. spread

Pterocarya lævigata. $4 \mathrm{ft}$. high.

$6 \mathrm{ft}$. high.

8 to $12 \mathrm{ft}$. high

Styrax, American. Styrax Americana. See Shrubs.

Silver Bell, Sn. Styrax Americana. See Shrubs. $2 \mathrm{ft}$. high

$3 \mathrm{ft}$. high

$4 \mathrm{ft}$. high

$7 \mathrm{ft}$. high

$10 \mathrm{ft}$. high, 8 to $10 \mathrm{ft}$. spread

$14 \mathrm{ft}$. high, $14 \mathrm{ft}$. spread

Thorn, Paul's Double Scarlet; Hawthorn. Cratagus monogyna, var. Pauli. $4 \mathrm{ft}$ high.

Thorn, Cockspur. $\ddot{C}$. Crus-galli. (Sheared): $3 \frac{1}{2} \mathrm{ft}$. high. $4 \mathrm{ft}$. high

$5 \mathrm{ft}$. high

$6 \mathrm{ft}$. high

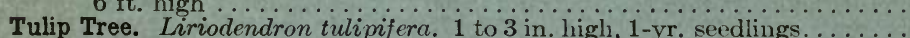

$1 \mathrm{ft}$. high

$2 \mathrm{ft}$. high

$4 \mathrm{ft}$. high

$6 \mathrm{ft}$. high

$8 \mathrm{ft}$. high

$10 \mathrm{ft}$. high, $1 \frac{1}{4}$ to 2 in. diam., 4 to $6 \mathrm{ft}$. spread

.

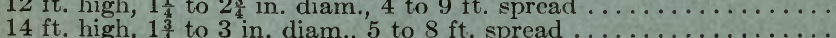

$16 \mathrm{ft}$. high, $2 \frac{1}{2}$ to $3 \mathrm{in}$. diam., 5 to $9 \mathrm{ft}$. spread $\ldots \ldots \ldots \ldots \ldots \ldots \ldots \ldots \ldots \ldots \ldots$

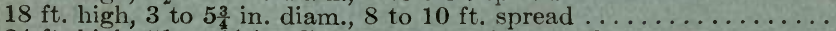

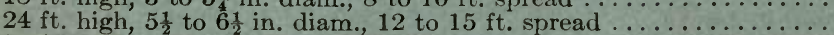

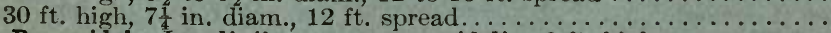
Tulip, Pyramidal. L. tulipifera, var. pyramidalis. $6 \mathrm{ft}$ high $\ldots \ldots \ldots \ldots \ldots$

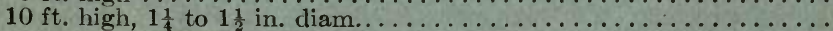

Yellow-wood. Cladrastis tinctoria. 4 to 9 in. high $\ldots \ldots \ldots \ldots \ldots \ldots \ldots \ldots \ldots$ $4 \mathrm{ft}$. high

$6 \mathrm{ft}$. high

$8 \mathrm{ft}$. high

$\ldots \ldots \ldots \ldots$

$20 \mathrm{ft}$. high, $6 \frac{3}{4}$ in. diam., $18 \mathrm{ft}$. spread.

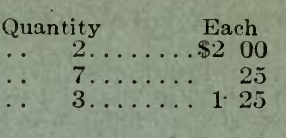

$40 \ldots \ldots \ldots 100$

$20 \ldots \ldots \ldots 12$

$20 \ldots \ldots \ldots 200$

$\$ 750$

1000

1500

1750

$30 \ldots \ldots 200$

$20 \ldots \ldots \ldots 250$

$12 \ldots \ldots .30$

$12 \ldots \ldots .350$

$2 \ldots \ldots$
3 $\ldots \ldots 00$

$6 \ldots . \ldots .1500$

$6 \ldots \ldots \ldots 100$

$2 \ldots \ldots \ldots 150$

$2 \ldots \ldots \ldots 1000$

$50 \ldots \ldots \ldots$

$30 \ldots \ldots \ldots 100$

$7 \ldots \ldots \ldots 125$

$20 \ldots \ldots \ldots 150$

$50 \ldots \ldots \ldots 175$

$5 \ldots \ldots 2000$

$5 \ldots \ldots 4500$

$3 \ldots \ldots .4000$

$2 \ldots \ldots 6000$

1500

1800

2500

3000

\section{0}

800

1200

1250

$25 \ldots \ldots \ldots \quad 50$

400

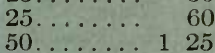

$190 \ldots \ldots \ldots .10$

$80 \ldots \ldots \ldots 15$

$6 \ldots \ldots \ldots 100$

$2 \ldots \ldots 200$

$1 \ldots \ldots 2500$

$4 . \ldots \ldots 500$

$\begin{array}{ll}25 \ldots \ldots \ldots & 25 \\ 12 \ldots \ldots \ldots & 50\end{array}$

$8 \ldots \ldots \ldots$ 75

$400 \ldots \ldots \ldots 10$

$125 \ldots \ldots \ldots \ldots$

$60 \ldots \ldots \ldots 2$

$60 \ldots \ldots \ldots$

$5 \ldots \ldots \ldots 100$

$2 \ldots \ldots \ldots 300$

$1 \ldots \ldots \ldots 1200$

$10 \ldots \ldots \quad 75$

$130 \ldots \ldots \ldots$

$700 \ldots \ldots \ldots$

$250 \ldots \ldots 35$

$80 \ldots \ldots .60$

$225 \ldots \ldots \ldots$

$300 \ldots \ldots 20$

$200 \ldots \ldots \ldots 25$

$50 \ldots \ldots \ldots \quad 50$

$70 \ldots \ldots \ldots .85$

$70 \ldots \ldots \ldots 100$

$70 \ldots \ldots \ldots 150$

$80 \ldots \ldots \ldots 250$

$25 \ldots \ldots \ldots 300$

$5 \ldots \ldots \ldots 500$

$6 \ldots \ldots$ s 00

$4 \ldots \ldots .3000$

$1 \ldots \ldots \ldots 4000$

$4 \ldots \ldots \ldots 200$

$5 \ldots \ldots \ldots 250$

$3 \ldots \ldots \ldots 300$

$50 \ldots \ldots \ldots .15$

$5 \ldots \ldots \ldots .75$

$20 \ldots \ldots \ldots 100$

$\begin{array}{llll}20 \ldots \ldots \ldots & 1 & 00 \\ 20 \ldots \ldots \ldots & 1 & 25\end{array}$

$4 \ldots \ldots \ldots 300$

$1 \ldots \ldots \ldots 1500$
200

400

$\begin{array}{rrrr} & 80 & 500 \\ 1 & 25 & 1000 \\ 2 & 00 & & \end{array}$

$\begin{array}{rr}5 & 00 \\ 10 & 00\end{array}$

80
125

$\$ 500$

800

600

225

250

300

500

80

180

200

400

750

$\begin{array}{lll}9 & 00\end{array}$

1250

2000

2250

100

800

1000
2000

2200

4000

500

1500

1800 
EVERGREEN TREES, WILLOW to ARBORVITA.

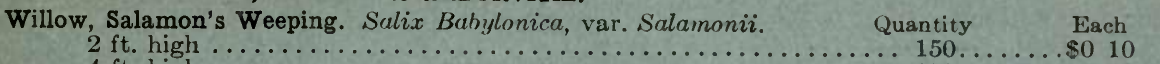

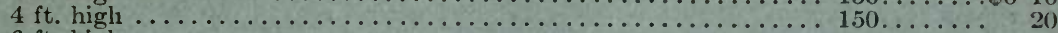

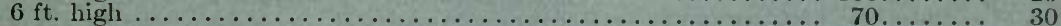

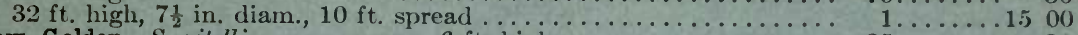

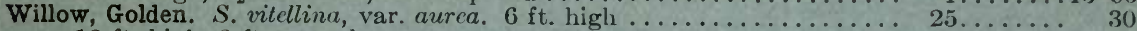

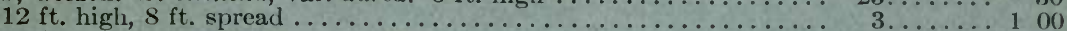

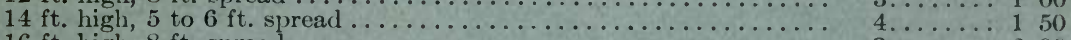

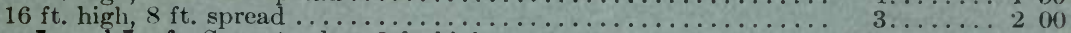

Willow, Laurel-Leaf. S. pentandra. $2 \mathrm{ft}$. high .

$3 \mathrm{ft}$. high

$4 \mathrm{ft}$. high

$250 \ldots \ldots \ldots 15$

$8 \mathrm{ft}$. high

$20 \mathrm{ft}$. high, $7 \frac{1}{2}$ in. diam., $15 \mathrm{ft}$. spread

Willow, Red-barked. S. vitellina, var. Britzensis. $3 \mathrm{ft}$. high $5 \mathrm{ft}$. high $7 \mathrm{ft}$. high

walnut, Black. Juglans nigra. $3 \mathrm{ft}$. high. $5 \mathrm{ft}$. high.

$10 \mathrm{ft}$. high, $1 \frac{1}{4}$ to $1 \frac{3}{4}$ in. diain., 4 to $10 \mathrm{ft}$. spread

$16 \mathrm{ft}$. high, $3 \frac{1}{4}$ to $4^{1} \mathrm{in}$. cliam., $10 \mathrm{ft}$. spread

$18 \mathrm{ft}$. high, 4 to 5 in. diam., 9 to $14 \mathrm{ft}$. spread

Walnut, Butternut $J$. cincrea. $2 \mathrm{ft}$. high.

$5 \mathrm{ft}$. high ...

$8 \mathrm{ft}$. high

Walnut, English. $J$. regia. $1 \mathrm{ft}$. high

$12 \mathrm{ft}$. high, $1 \frac{1}{4}$ to $1 \frac{1}{2} \mathrm{in}$. diam.

Walnut, Japan. J. cordiformis. $3 \mathrm{ft}$. high

$4 \mathrm{ft}$. high ..........

$6 \mathrm{ft}$. high

$10 \mathrm{ft}$. high, $1 \frac{1}{4}$ to $2 \frac{3}{4}$ in. diam., 4 to $8 \mathrm{ft}$. spread

$16 \mathrm{ft}$. high, 5 in. diam., $12 \mathrm{ft}$. spread

$20 \mathrm{ft}$. high, $6 \mathrm{in.}$ diam., $18 \mathrm{ft}$. spread.

Zelkova acuminata; syn., Z. Keaki (Japanese Elm).

10 to $12 \mathrm{ft}$., 2 to $2 \frac{1}{2}$ in. diam.,

$18 \mathrm{ft}$. high, $\$ \frac{1}{2}$ in. dian., $17 \mathrm{ft}$. spread.

$\begin{array}{rr}250 \ldots \ldots & 15 \\ 200 \ldots \ldots & 20 \\ 65 \ldots \ldots & 25\end{array}$

$25 \ldots \ldots$
$1 \ldots \ldots 66^{60}$

$1 \ldots \ldots \ldots$
$190 \ldots \ldots$

$\begin{array}{lll}20 & \cdots & 30 \\ 10 & \cdots & 40\end{array}$

$\begin{array}{lll}10 \ldots \ldots & 40 \\ 15 \ldots \ldots & 40\end{array}$

$\begin{array}{ll}15 \ldots \ldots & 40 \\ 70 \ldots \ldots, 50 & 50\end{array}$

$7 \ldots \ldots \ldots 1$
2 $\ldots \ldots .500$

$3 \ldots \ldots \ldots 800$

$10 \ldots \ldots \ldots \quad 25$

$10 \ldots \ldots \ldots 100$

$\begin{array}{rr}20 \ldots \ldots \ldots & 40 \\ 5 \ldots \ldots \ldots & 00 \\ 32 \ldots \ldots & 15\end{array}$

$\begin{array}{ll}32 \ldots \ldots & 15 \\ 30 \ldots \ldots & 20\end{array}$

$35 \ldots \ldots \ldots \quad 30$

$15 \ldots \ldots \ldots 100$

$1 \ldots \ldots \ldots 1200$
$1 \ldots \ldots \ldots 1500$

Per 10

\$O 90 S\& UO

$\begin{array}{lll}175 & 1500\end{array}$

250

200

125

150

200

1000

500

150

250

$\begin{array}{lll}3 & 00\end{array}$

300

400

1000

200

600

900

300

125

12 on

150

1200

$3 \ldots \ldots \ldots 100$

$1 \ldots \ldots 2000$

\section{Evergreen Trees (Conifers)}

Several years ago we deeided that Long Island nceded evergreens to make it a more ideal residence region. The usual method of importing small evergreens for immediate sale or to grow on, is expensive and ultimately unsatisfactory, because many of the varieties are not permanently suecessful.

Therefore, we collected seed from Long Island trees and grew trees in large quantities so that we could offer them at low prices. We believe there is no other opportunity in the eastern United States to purchase evergreens so eheaply. Of the large sizes, 6 to 30 feet high, we have several thousand. These are root-pruned and ready for delivery at any time of the year. These trees give immediate, all-the-year-round service, and are priced as low as is consistent with the expense of handling such heavy trees.

We have invented methods for suecessfully clamping large balls of earth of several tons weight and holding them securely until p anted. For illustrations showing this stoek, and the results attained by planting it, send for our Catalogue, "Large Evergreens for Immediate Planting." Prices in the latter are superseded by the prices in this list.

The cheapest way to get large evergreens in large quantities is in car-load lots direet from the eollecting fields. We have over fifty ear-loads of White Pine, White Spruce and Red Pine, root-pruned, ready for shipment in August, 1909. These trees are from 8 to 22 feet in height. They are broad, bushy specimens, which will give immediate results for ornament, windbreak or sereen. Samples of these trees may be seen at our nurseries, and photographs of them will be sent upon application. These large, eollected trees are eheap beeause the only expense is that of collecting them. There is praetically no expense for the many years they have been growing.

BALL OF EARTH. All of our evergreens are dug with a ball of earth except the small sizes, as the Pines and Spruces up to $1 \frac{1}{2}$ or 2 feet. Therefore, in comparing priees, please remember that our evergreens have more than twice as much roots as the average, and that failure is very rare with them. They make vigorous, dense growth from the start. See pages 38 and 39 .

Arborvitæ, American. Thuya occidentalis. 6 to $12 \mathrm{in}$. high

$$
\text { Quantity }
$$

$2 \mathrm{ft}$. high

$3 \mathrm{ft}$. high

$5 \mathrm{ft}$. high, 2 to $3 \mathrm{ft}$. spread

$6 \mathrm{ft}$. high, 3 to $4 \mathrm{ft}$. spread

$7 \mathrm{ft}$. high, 2 to $3 \mathrm{ft}$. spread

$8 \mathrm{ft}$. high, 3 to $4 \mathrm{ft}$. spread

$9 \mathrm{ft}$. high, 3 to $4 \mathrm{ft}$. spread

$10 \mathrm{ft}$. high, 4 to $5 \mathrm{ft}$. spread

$12 \mathrm{ft}$. high, $3 \frac{1}{2}$ to $4 \mathrm{ft}$. spread
$14 \mathrm{ft}$. high, 4 to $6 \mathrm{ft}$. spread.

$16 \mathrm{ft}$. high, $6 \mathrm{ft}$. spread

Arborvitæ, Siberian. T. occidentalis, var. Warcana; syn., T. Sibirica.

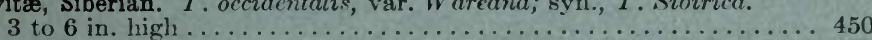

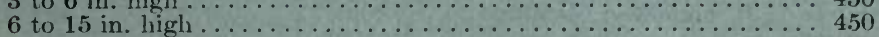

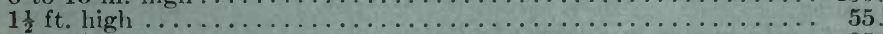

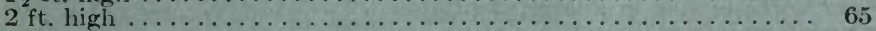

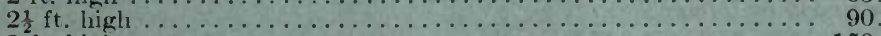

$3 \mathrm{ft}$. high

$4 \mathrm{ft}$. high, 2 to $3 \mathrm{ft}$. spread.

150 .

75.

$55 \ldots$

......\$0 10

$\begin{array}{ll}45 \ldots \cdots \cdots & 40 \\ 25 & 75\end{array}$

$65 \ldots \ldots \ldots 150$

$45 \ldots \ldots \ldots 250$

$13 \ldots \ldots \ldots+400$

$12 \ldots \ldots \ldots 500$

$1 \ldots \ldots 2500$

$5 \mathrm{ft}$. high, $2 \frac{1}{2}$ to $3 \mathrm{ft}$. spread . . . . . . . . . . . . . . . .
Each

$\begin{array}{ll}5 & 00 \\ 8 & 00\end{array}$

900

1200

.1500

1800

Per 10

$\$ 090$

350

600

1250

2000

3000

4000

7000

so 00

11000

$\$ 800$

5000

- $20 \quad 180$

225

100

$\begin{array}{ll}1 & 50\end{array}$

175

200

400

900

1250

1500

1600

2500

3500
1500

2000

150 or 
EVERGREEN TREES, ARBORVITAE to CEDAR.

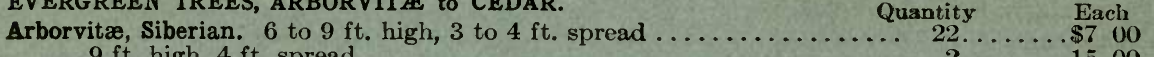

Per 10

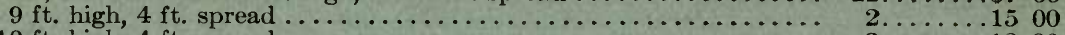

$\$ 6000$

Per 100

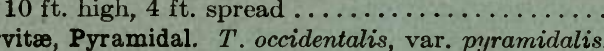

Arborvitæ, Pyramidal. $T$. occide
$4 \mathrm{ft}$. high, $1 \mathrm{ft}$. spread

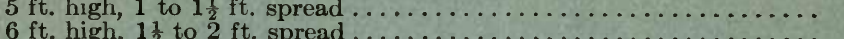

$7 \mathrm{ft}$. high, 2 to $3 \mathrm{ft}$. spread .

$8 \mathrm{ft}$. high, 2 to $3 \mathrm{ft}$. spread

$10 \mathrm{ft}$. high, 2 to $3 \mathrm{ft}$. spread

$2 \ldots \ldots 1800$

$12 \mathrm{ft}$. high, $4 \mathrm{ft}$. spread

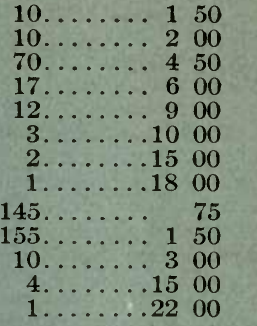

1250

1750

4000

5000

8000

Arborvitæ, Booth's. T. occidentalis, var. Boothii. $1 \mathrm{ft}$. high........ 14

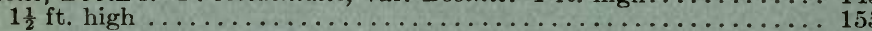

2 ft. high

$7 \mathrm{ft}$. high, 6 to $7 \mathrm{ft}$. spread.

$9 \mathrm{ft}$. high, $8 \mathrm{ft}$. spread

Arborvitæ, Dwarf. T. occidentalis, var. globosa.

$2 \mathrm{ft}$. high, $1 \frac{1}{2}$ to $3 \mathrm{ft}$. spread

$3 \mathrm{ft}$. high, 2 to $3 \mathrm{ft}$. spread

$25 \ldots \ldots 250 \quad 2250$

$11 \ldots \ldots .300 \quad 2500$

600

1000

$\$ 5000$

2250

8000

Arborvitæ, Golden, or George Peabody. T. occidentalis, var. lutea. $1 \mathrm{ft}$. high

$2 \mathrm{ft}$. high

$3 \mathrm{ft}$. high

$4 \mathrm{ft}$. high

$5 \mathrm{ft}$. high, 2 to $2 \frac{1}{2} \mathrm{ft}$. spread

$6 \mathrm{ft}$. high, 2 to $3 \mathrm{ft}$. spread.

Arborvitæ, Chinese. T. orientalis; syn., Biota orientalis.

6 to $18 \mathrm{in}$. high. Scedlings

$1 \mathrm{ft}$. high

$2 \mathrm{ft}$. high

$9 \mathrm{ft}$. high

$\begin{array}{rrrrr}20 \ldots \ldots & \ldots & 50 & 4 & 00 \\ 10 \ldots \ldots & 1 & 00 & 9 & 00 \\ 32 \ldots \ldots & 1 & 50 & 12 & 50 \\ 30 \ldots \ldots & 3 & 00 & 20 & 00 \\ 14 \ldots \ldots & 3 & 50 & 25 & 00 \\ 10 \ldots \ldots & 4 & 00 & 30 & 00\end{array}$

$480 \ldots \ldots 02 \quad 20$

150

$75 \ldots \ldots \ldots 06$

$30 \ldots \ldots \quad 10$

$1 \ldots \ldots \ldots 300$

$8 \ldots \ldots \ldots 50$

$3 \ldots \cdots \cdots, 75$

$4 \mathrm{ft}$. high, $1 \frac{1}{2}$ to $2 \mathrm{ft}$. spread

$8 \frac{1}{2} \mathrm{ft}$. high, $3 \mathrm{ft}$. spread

Arborvitæ, Standish Japanese. T. Japonica; syn., Thuyopsis Standishii.

$3 \mathrm{ft}$. high, $1 \frac{1}{2}$ to $2 \mathrm{ft}$. spread

$4 \mathrm{ft}$. high, 2 to $3 \mathrm{ft}$. spread

$1 \ldots \ldots 400$

$\begin{array}{lll}10 \ldots \ldots & \ldots & 75 \\ 14 \ldots \ldots & \ldots & 50 \\ 12 \ldots & \ldots & 0\end{array}$

600

1000

1500

70

140

300

450

800

1400

1850

400

$1 \mathrm{ft}$. high

$3 \mathrm{ft}$. high

$350 \ldots \ldots$

$875 \ldots \ldots 60$

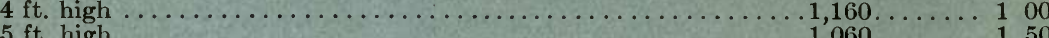

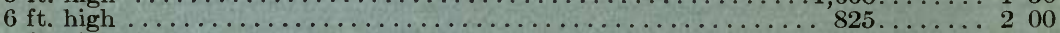

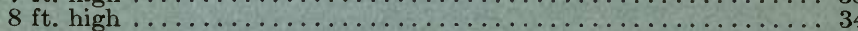

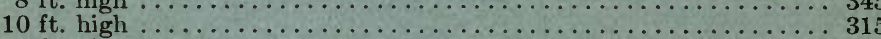

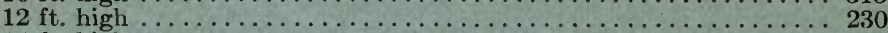

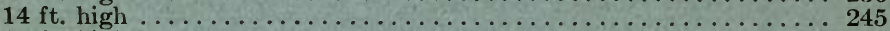

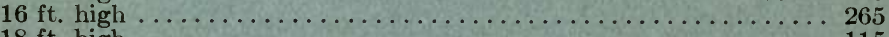

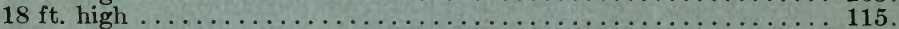

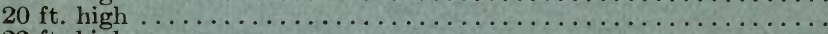

$22 \mathrm{ft}$. high

$24 \mathrm{ft}$. high

$26 \mathrm{ft}$. high

$28 \mathrm{ft}$. high

$30 \mathrm{ft}$. high

It used to be considered impracticable to transplant the Red

Cedar. We have learned how. The large quantities in stock enable you to pick out specimens of any size, and of quality for any purpose, from the irregular trees, suited to mass planting to the sheared specimens for formal gardens. These can be shipped in car-load lots at any time. Therefore it is possible to make a permanent evergreen screen 25 feet high, no matter where you are located.

Cedar Arches. $8 \mathrm{ft}$. high, $7 \mathrm{ft}$. spread. .

These arches have been trained for several years and will give a mature effect to a garden similar to that of the old topiary work in

English gardens. See page 33.

Cedar, Blue. J. Virginiana, var. glauca. $6 \mathrm{ft}$. high . .

Cedar, Blue, Mt. Atlas. Cedrus Atlantica, var. glauca. (Grafted.)

$2 \mathrm{ft}$. high

$3 \mathrm{ft}$. high

$5 \mathrm{ft}$ high, $2 \mathrm{ft}$ spread $\cdots \ldots \ldots \ldots \ldots \ldots \ldots \ldots \ldots \ldots$

$7 \mathrm{ft}$. high, $3 \mathrm{ft}$ spread

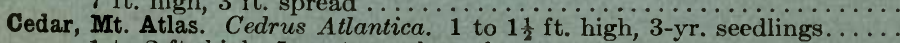

1 to $2 \mathrm{ft}$. Ced 5 -yr. tranci. 1 to $1 \frac{1}{2}$. high, $3-y r$ seedlings.

These trees at $\$ 5$ per 100 are worth mixing in a large plantation of Pines and Spruce for their sparkling foliage.

Cedar of Lebanon. Cedrus Libani. 2 to $3 \mathrm{ft}$. high, 1 to $1 \frac{1}{2} \mathrm{ft}$. spread ....

Cedar, White. Chamacyparis sphoroides; syn., Cupressus thuyoides.

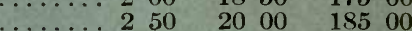

$4 \mathrm{ft}$. high

60.

$\ldots \ldots$

$\ldots \ldots$

$60 \ldots \ldots \ldots$

$45 \ldots \ldots$

45 .

20 .

$7 \ldots$

$1 \ldots \ldots \ldots$

Price on selection

600

1200

3500

7000

12500

18500

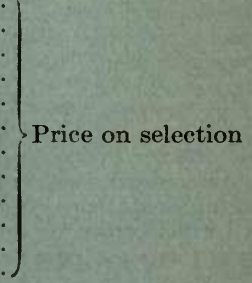

$\ldots \ldots 3200 \quad 300 \quad 00$

3..... 2.50

$35 \ldots \ldots \ldots 125 \quad 1000$

$50 \ldots \ldots \ldots 200 \quad 1500$

$10 \ldots \ldots \ldots 400 \quad 3000$

$9 \ldots \ldots \ldots 500 \quad 4000$

$800 \ldots \ldots \ldots .50$

$15 \ldots \ldots \ldots \quad 50 \quad 400$

500

$8 \ldots \ldots 100$

$50 \ldots \ldots 25$ 
EVERGREEN TREES, CEPHALOTAXUS to HEMLOCK.

Cephalotaxus Fortunei. $4 \mathrm{ft}$. high, 3 to $4 \mathrm{ft}$. spread .

Quantity

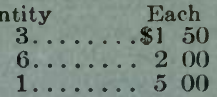

$8 \mathrm{ft}$ high, $5 \mathrm{ft}$ spread.

These are domes of shining, dark green, Yew-like foliage, suitable for planting in sheltered, moist woodland

Cupressus Lawsoniana, var. Triumph de Boskoop. 2 to $3 \mathrm{ft}$. high .......

Gryptomeria Lobbi. 2 to $2 \frac{1}{2} \mathrm{ft}$. high.

Fir, Nordmann's. Abies Nordmanniana.

2 to 4 in. high, 3 -yr. seedlings ...

$1 \mathrm{ft}$. high.

$2 \mathrm{ft}$. high

$2 \frac{1}{2} \mathrm{ft}$. high

$3 \mathrm{ft}$. high, 3 to $4 \mathrm{ft}$. spread

$4 \mathrm{ft}$. high

$5 \mathrm{ft}$. high, 3 to $5 \mathrm{ft}$. spread

$6 \mathrm{ft}$. high, 3 to $6 \mathrm{ft}$. spread

$7 \mathrm{ft}$. high, 4 to $6 \mathrm{ft}$. spread

$8 \mathrm{ft}$. high, 4 to $6 \mathrm{ft}$. spread .

$9 \mathrm{ft}$. high, 5 to $7 \mathrm{ft}$. spread

$10 \mathrm{ft}$. high, 5 to $8 \mathrm{ft}$. spread

$12 \mathrm{ft}$. high, 7 to $8 \mathrm{ft}$. spread

$14 \mathrm{ft}$. high, 7 to $10 \mathrm{ft}$. spread

$17 \mathrm{ft}$. high, 9 to $10 \mathrm{ft}$. spread

$19 \mathrm{ft}$. high, 9 to $11 \mathrm{ft}$. spread

This is especiafly rich and imposing on Long Island, and our specimens are worth the consideration of landscape planters.

Fir, silver. A. pïова; syn, A. pectinata.

$12 \mathrm{ft}$. high, 4 to $9 \mathrm{ft}$ : spread

14 ft. high, 6 to $7 \mathrm{ft}$. sppread

$16 \mathrm{ft}$. high, 7 to $8 \mathrm{ft.}$ : spread

$18 \mathrm{ft}$. high, 8 to $9 \mathrm{ft}$. spread

$21 \mathrm{ft}$. high, 9 f.t. spread

Fir, Cephalonian. A. Cephalonïca.

2 to 6 in. high, 3 -yr. seedling

4 ft. high, 3 f.t. spread ................

$8 \mathrm{ft.}$ high, 6 to $7 \mathrm{ft.}$ spread

$10 \mathrm{ft}$. high, 7 to $8 \mathrm{ft}$. spread

$12 \mathrm{ft}$. high, $8 \mathrm{ft}$. spread

$18 \mathrm{ft}$. high, $9 \mathrm{ft}$. spnead.

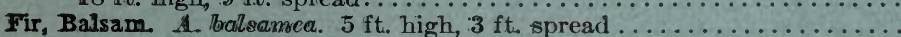

Fir, Fraser's Balsam. A. Fraseri. $4 \mathrm{ft}$. high, $2 \frac{1}{2}$ to $3 \mathrm{ft}$. spread.

$5 \mathrm{ft}$ high, $3 \mathrm{ft}$. spread ...

6 ft. high, 3 to $3 \frac{1}{2} \mathrm{ft}$. spread

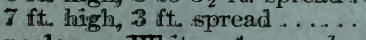

Fir, Concolor, or White. A. concolor. 4 to 12 in. high.

1 ft. high

$1 \frac{1}{2} \mathrm{ft}$. high

$2 \frac{1}{2} \mathrm{ft}$. high

$3 \mathrm{ft}$ high, 2 to $2 \frac{1}{2} \mathrm{ft}$. spread

$4 \mathrm{ft}$. high, $2 \frac{1}{2}$ to $3 \frac{1}{2} \mathrm{ft}$. spread

$5 \mathrm{ft}$. high, 3 to $4 \mathrm{ft}$. spread

$6 \mathrm{ft}$. high, 3 to $4 \mathrm{ft}$. spread

$10 \mathrm{ft}$. high, 6 to $7 \mathrm{ft}$. spread

Some day people will be proud to have a specimen of this species

on their lawns. They will harmonize with other evergreens.

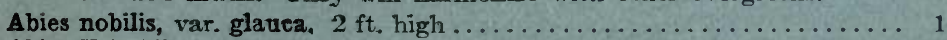

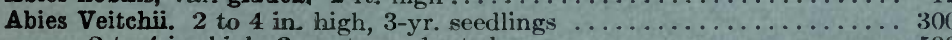

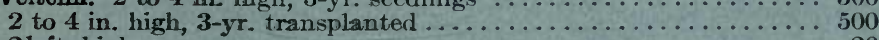

$2 \frac{1}{2} \mathrm{ft}$. high

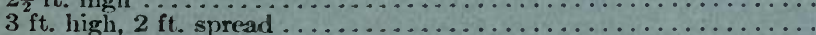

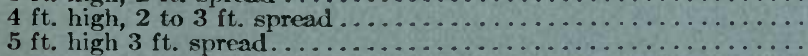

$6 \mathrm{ft}$. high, 3 to $4 \mathrm{ft}$. sprear

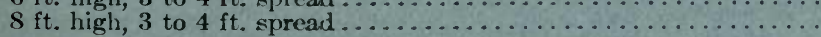

Abies subalpina. $2 \mathrm{ft}$. high

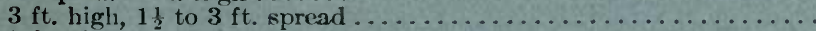

$5 \mathrm{ft}$. high, $3 \mathrm{ft}$. spread

$11 \mathrm{ft}$. high, $6 \mathrm{ft}$. spread

$\begin{array}{lll}25 \ldots \ldots & 00 \\ 25 \ldots \ldots & 75\end{array}$

$\$ 900$

600

$800 \ldots \cdots \cdots+15$

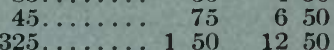

$60 \ldots \ldots \ldots 200$

$150 \ldots \ldots \ldots 300$

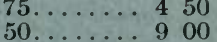

$45 \ldots \ldots 1200$

$30 \ldots \ldots 1400$

$30 \ldots \ldots \ldots 1600$

$9 \ldots \ldots .1800$

$19 \ldots \ldots 2200$

$10 \ldots \ldots \ldots 2500$

$13 \ldots \ldots .4000$

$3 \ldots \ldots .5000$

$4 \ldots \ldots .9000$

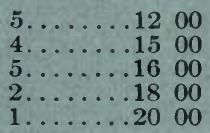

$900 \ldots \ldots \ldots 10$

$2 \ldots \ldots \cdots 150$

$4 \ldots \ldots .800$

$2 \ldots \ldots .1500$

$2 \ldots \ldots 2000$

$1 \ldots \ldots 2500$

$1 \ldots \ldots .9000$

$8 \ldots \ldots \ldots 75$

$28 \ldots \ldots \ldots 150$

$13 \ldots \ldots \ldots 200$

$18 \ldots \ldots .300$

$13 \ldots \ldots .400$

$800 \ldots \ldots \quad 40$

$350 \ldots \ldots 7 \quad 75$

$30 \ldots \ldots \ldots 100$

$8 \ldots \ldots 250$

$45 \ldots \ldots .300$

$55 \ldots \ldots \ldots 500$

$22 \ldots \ldots 6600$

$9 \ldots \ldots 1200$

$2 \ldots \ldots \ldots 2500$

2500

2....2 250

10

$20 \ldots \ldots \cdots 200$

$18 \ldots \ldots \ldots 30$

$11 \ldots \ldots \ldots 350$

$8 \ldots \ldots \ldots 400$

$20 \ldots \ldots 6600$

$2 \ldots \ldots .800$

$11 \ldots \ldots 200$

$2 \ldots \ldots 300$

$1 \ldots \ldots \ldots 50$

$1 \ldots \ldots 2500$

Abies Sibirica. $2 \mathrm{ft}$. high

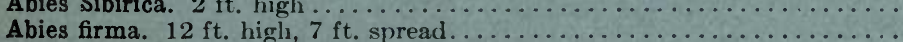

Abies homolepis; syn., brachyphylla. 6 to 12 in. high

$1 \mathrm{ft}$. high

$3 \mathrm{ft}$. high,

$6 \mathrm{ft}$. high

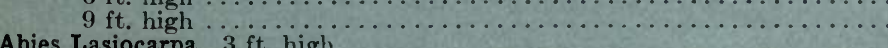

Hemlock, American. Tsuga Canadensis. 1 ft. high.

$40 \ldots \ldots+50$

$4 \ldots \ldots \times 800$

20

45

35

10
3

3.

10

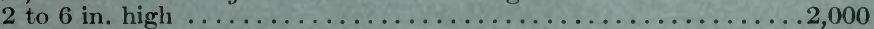

$2 \mathrm{ft}$. high

200

$3 \mathrm{ft}$. high

250
120

450

1750

2500

4000

7500

10000

12000

14000

16000

20000

23000

38000

1250

2000

2500

3500

350

650

900

4500

5500

3000

6000

$\$ 1000$

4000

10000

22500

35000

500

2000

90

125

1750

2500

3000

4500

350

600

1000

3000

400

800

1500

75

100

30

15

75
125

7500

600

700

250

100

600

1000

500

1000

2000

800

$\begin{array}{rl}50 & 00 \\ 85 & 00\end{array}$
1500 
EVERGREEN TREES, HEMLOCK to PINE.

Hemlock, American. $4 \mathrm{ft}$. high, 2 to $4 \mathrm{ft}$. spread

$5 \mathrm{ft}$. high, 2 to $4 \mathrm{ft}$. spread

$6 \mathrm{ft}$. high, 3 to $4 \mathrm{ft}$. spread .

$7 \mathrm{ft}$. high, 4 to $5 \mathrm{ft}$. spread

$8 \mathrm{ft}$. high, 4 to $5 \mathrm{ft}$. spread

$10 \mathrm{ft}$. high, 4 to $6 \mathrm{ft}$. spread

$12 \mathrm{ft}$. high, $16 \mathrm{ft}$. spread

$14 \mathrm{ft}$. high, 8 to $10 \mathrm{ft}$. spread

$16 \mathrm{ft}$. high, 8 to $10 \mathrm{ft}$. spread

$20 \mathrm{ft}$. high, $12 \mathrm{ft}$. spread

$22 \mathrm{ft}$. high, 12 to $14 \mathrm{ft}$. spread

$24 \mathrm{ft}$. high, 12 to $14 \mathrm{ft}$. spread

$26 \mathrm{ft}$. high, $12 \mathrm{ft}$. spread

$28 \mathrm{ft}$. high, $14 \mathrm{ft}$. spread

Hemlock Hedges. $7 \mathrm{ft}$. higl, $6 \mathrm{ft}$. spread

$8 \mathrm{ft}$. high, $7 \mathrm{ft}$. spread

$12 \mathrm{ft}$. high, $10 \mathrm{ft}$. spread

$12 \mathrm{ft}$. high, $12 \mathrm{ft}$. spread

$29 \mathrm{ft}$. high, $24 \mathrm{ft}$. spread

We have successfully transplanted several Hemlock hedges, so Quantity $\quad$ Each

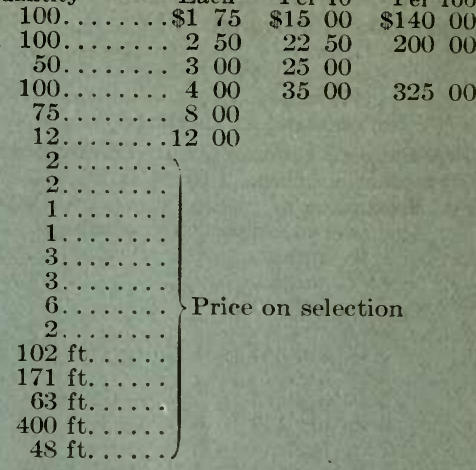

that we know what rich and dignified results may be obtained the first year.

The Hemlock always keeps good foliage at the bottom because of its drooping habit. In case, however, any gaps occur, they may be immediately filled by a small plant which blends with the older plants. Architects should consider this material in comparison with brick and stone walls for garden enclosures or screens.

Hemlock, Carolina. $T$. Caroliniana. $3 \mathrm{ft}$. high. $5 \mathrm{ft}$. high, 3 to $4 \mathrm{ft}$. spread.

We offer an unusual variety of sizes of Hemlock, ranging in age from three years to forty years. All the stock has been root-pruned and is in excellent condition for transplanting.

Juniper, Irish. Juniperus communis, var. Hibernica. $1 \frac{1}{2} \mathrm{ft}$. high $2 \frac{1}{2} \mathrm{ft}$. high

$4 \mathrm{ft}$. high

Juniper, Common. J. communis, var. Canadensis

$1 \mathrm{ft}$. high, $1 \frac{1}{2}$ to $2 \mathrm{ft}$. spread

$2 \mathrm{ft}$. high, 3 to $4 \mathrm{ft}$. spread

Juniper, Golden. J. communis, var. Canadensis aurea.

1 to $2 \mathrm{ft}$. high, $2 \mathrm{ft}$. spread.

1 to $2 \mathrm{ft}$. high, $3 \mathrm{ft}$. spread

1 to $2 \mathrm{ft}$. high, $4 \mathrm{ft}$. spread

These plants are priced low because we wish to clear the blocks where they are growing. They have been pruned to make the foliage dense.

Juniper, Chinese, Upright Form. J. Chinensis.

$4 \mathrm{ft}$. high, 1 to $2 \mathrm{ft}$. spread $\ldots \ldots \ldots \ldots \ldots \ldots \ldots \ldots \ldots \ldots \ldots \ldots$
$5 \mathrm{ft}$. high, 2 to $3 \mathrm{ft}$ spread $\ldots \ldots \ldots \ldots \ldots \ldots \ldots \ldots \ldots$

$5 \mathrm{ft}$. high, 2 to $3 \mathrm{ft}$. spread

$1 \mathrm{~s} \ldots \ldots \ldots 200$

$13 \ldots \ldots \ldots+350$

$5 \ldots \ldots .400$

Juniper, Prostrate, or Trailing. J. Sabina, var. prostrata.

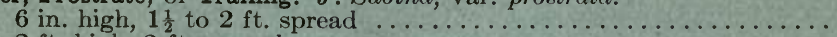
$2 \mathrm{ft}$. high, $2 \mathrm{ft}$. spread

Juniperus Virginiana, var. tripartita. $3 \mathrm{ft}$. higl. $4 \mathrm{ft}$. high.

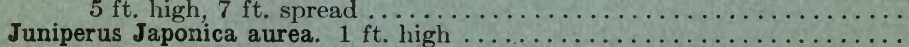

Pine, White. Pinus Strobus.

4 to 6 in. high, seedlings.

3 to 6 in. high, 3 -yr. transplanted

Per $1,000, \$ 8 \ldots 2,000$

$38 \ldots \ldots \ldots 100$

$9 \ldots \ldots \ldots 200$

$11 \ldots \ldots \ldots 100$

$5 \ldots \ldots \cdots 1125$

$1 \ldots \ldots \ldots 1000$

$17 \ldots \ldots \ldots+75$

300

6 to 12 in

$1 \mathrm{ft}$. high, 5 -yr. twice transplanted ..................... $1,000, \$ 90 \ldots 5,000 \ldots \ldots \ldots$

Pine, White. $1 \frac{1}{2} \mathrm{ft}$. high ............................... $1,000, \$ 100 \ldots 1,700$

$2 \mathrm{ft}$. high

$3 \mathrm{ft}$. high,

Per $1,000, \$ 150 \ldots 6,000$

$4 \mathrm{ft}$. high

$1,010 \ldots \ldots \ldots$

$5 \mathrm{ft}$. high

$815 \ldots \ldots 100$

$6 \mathrm{ft}$. high

, 075

$655 \ldots \ldots \ldots 300$

$7 \mathrm{ft}$. high

$355 \ldots \ldots \ldots 400$

$8 \mathrm{ft}$. high
$10 \mathrm{ft}$. high

$12 \mathrm{ft}$. high

$14 \mathrm{ft}$. high

$100 \ldots \ldots \ldots 800$

$30 \ldots \ldots 1200$

1750

3000

900

800

600

$16 \mathrm{ft}$. high

$18 \mathrm{ft}$. high

$30 \ldots \ldots$

$20 \mathrm{ft}$. high

$28 \ldots \ldots \ldots$

$22 \mathrm{ft}$. high

26

$24 \mathrm{ft}$. high

28 .

Price on selection

$26 \mathrm{ft}$. high

13

$28 \mathrm{ft}$. higl

$8 \ldots$

$2 \ldots \ldots \ldots$

$32 \mathrm{ft}$. high

Pine, Pitch. Pinus rigida.

2 to 4 in. high, $1-y r$. seedlings $\ldots \ldots \ldots \ldots \ldots \ldots$ Per $1,000, \$ 5.8,000$

$1 \mathrm{ft}$. high

$2 \mathrm{ft}$. high

475

15 
EVERGREEN TREES, PINE.

Pine, Pitch. $3 \mathrm{ft}$. high

$4 \mathrm{ft}$ high

$5 \mathrm{ft}$. high

$6 \mathrm{ft}$. high

$7 \mathrm{ft}$. high

Pine, Scotch. P. sylvestris.

1 to 3 in. high, $1-y \mathrm{r}$. seedlings

$2 \mathrm{ft}$. high

$3 \mathrm{ft}$. hig

$4 \mathrm{ft}$. high

$5 \mathrm{ft}$. high

$24 \mathrm{ft}$. high, $13 \mathrm{ft}$. spread

Quantity
700

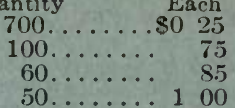

$30 \ldots \ldots \ldots 150$

Per $1,000, \$ 5 \ldots 2,000$

1,450

1,100

260 .

$$
1
$$

500

2 to 4 in. high, 1-yr. seedlings

6 to 12 in. high

1 to $1 \frac{1}{2} \mathrm{ft}$. high

$2 \mathrm{ft}$. high

$3 \mathrm{ft}$. high

$4 \mathrm{ft}$. higl

$6 \mathrm{ft}$. high, $5 \mathrm{ft}$. spread

$18 \mathrm{ft}$. high, $10 \mathrm{ft}$. spread

Pine, Japanese Red. P. densiflora

6 to 12 in., high seedlings.

$1 \mathrm{ft}$. high

$2 \mathrm{ft}$. high

$3 \mathrm{ft}$. high

$4 \mathrm{ft}$. high

$5 \mathrm{ft}$. high

$6 \mathrm{ft}$. high

Pine, Korean. P. Koraiensis. 6 to 12 in. high

$1 \mathrm{ft}$. high

$3 \mathrm{ft}$. high

$10 \mathrm{ft}$. high

Pine, Mugho, or Mountain. P. montana, var. Mughus.

4 to 8 in. high, 3-yr. seedlings

3 to 8 in. high, 3 -yr. transplanted .

$1 \mathrm{ft}$. high, $1 \mathrm{ft}$. spread

$1 \frac{1}{2} \mathrm{ft}$. high, $1 \frac{1}{2} \mathrm{ft}$. spread

$2 \mathrm{ft}$. high, $1 \frac{1}{2}$ to $2 \frac{1}{2} \mathrm{ft}$. spread

$3 \mathrm{ft}$. high, 2 to $3 \mathrm{ft}$. spread

$1 \frac{1}{2} \mathrm{ft} ., 4 \mathrm{ft}$. spread.

Pine, Red, or Norway. P. resinosa. 4 to 12 in. high, $3-y r$

$3 \mathrm{ft}$. high

$4 \mathrm{ft}$. ligh

$6 \mathrm{ft}$. high

$8 \mathrm{ft}$. high.

$15 \mathrm{ft}$. high, $10 \mathrm{ft}$. spread

Pine, Swiss Stone. P. cembra. 3 to 6 in. high

$1 \frac{1}{2}$ to $2 \mathrm{ft}$. ligh

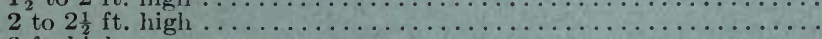

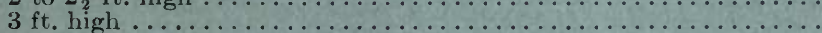

$4 \mathrm{ft}$. high

$11 \mathrm{ft}$. ligh

Per $1,000, \$ 25.1,500$

800

185

125.

13.

1 .

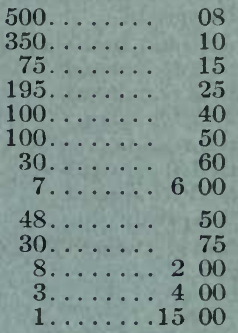

$\begin{array}{llll}3 & 00 & 25 & 00\end{array}$

$\begin{array}{lll}3 & 00 \\ 8 & 00\end{array}$

4000

400

100$$
15
$$

$8 \mathrm{ft}$. high, 6 to $8 \mathrm{ft}$. spread

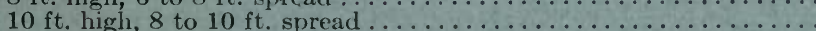

$12 \mathrm{ft}$. high, 7 to $12 \mathrm{ft}$. spread . .

$17 \mathrm{ft}$. high, 9 to $15 \mathrm{ft}$. spread

Pine, Scrub. P. contorta. $6 \mathrm{ft}$. high

Pine, Jack. P. divaricata; syn., P. Banksiana.; 1 to 3 in. high $3 \mathrm{ft}$. high

$4 \mathrm{ft}$. high

Pine, Western, Yellow, or Bull. P. ponderosa, 6 in. high

$$
1 \frac{1}{2} \mathrm{ft} \text {. high }
$$

Pinus parviflora. $3 \mathrm{ft}$. high

$$
7 \mathrm{ft} \text {. high . }
$$

Pinus Massoniana. 6 to $12 \mathrm{in.} \mathrm{high}$

Pine, Umbrella. Sciadopitys verticillata. 1 to $3 \mathrm{in}$. high.

$2 \frac{1}{2} \mathrm{ft}$. high

$4 \mathrm{ft}$. high

$6 \mathrm{ft}$. high

$9 \mathrm{ft}$. high
60

20.

20.

8 .

$\begin{array}{r}36 \\ 8 \\ \hline\end{array}$

8
40
45

40 .$$
6
$$

4

105

4
7
10

7
10
3

3.

130 .

130
4
3

$$
50
$$

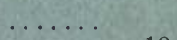

$\begin{array}{rrrr} & 50 & 300 \\ & 60 & 500 \\ 5 & 00 & 40 & 00 \\ 10 & 00 & & \\ 12 & 50 & & \\ 15 & 00 & & \\ 20 & 00 & & \end{array}$

300

$9 \ldots \ldots 5500$

$4 \ldots \ldots .900$

$2 \ldots \ldots 1200$

$2 \ldots \ldots 2000$

$35 \ldots \ldots \ldots 75$

$13 \ldots \ldots \ldots 100$

$40 \ldots \ldots \ldots 10$

$75 \ldots \ldots \ldots .30$

$30 \ldots \ldots .35$

$20 \ldots \ldots 10$

$12 \ldots \ldots \ldots \quad 40$

$18 \ldots 300$

$1 \ldots \ldots 8800$

$700 \ldots \ldots 05$

$90 \ldots \ldots \quad 40$

3...... 400

$5 . \ldots \ldots \ldots 600$

$7 \ldots \ldots 1200$

1...... 1800
125

.225

600

1500

60

90

125

200

300

450

500

400

600

200

300

2500

2500

90

800

125

1000

$\begin{array}{ll}20 & 00 \\ 50 & 00\end{array}$

10000

300

800

1500

2000

3500

600

900

90

200

250

90

300

2500

40

300

75

4000

4500
6000

$4 x^{2}$

300 
EVERGREEN TREES, RETINOSPORA to SPRUCE.

Retinospora plumosa viridis (Chamacyparis)

$4 \mathrm{ft}$. high $\because \ldots \ldots \ldots \ldots \ldots$

$6 \mathrm{ft}$. high, 4 to $5 \frac{1}{2} \mathrm{ft}$. spread

$8 \mathrm{ft}$. high, 6 to $7 \frac{1}{2} \mathrm{ft}$. spread
$10 \mathrm{ft}$. high, 6 to $7 \mathrm{ft}$. spread

$14 \mathrm{ft}$. high, $10 \mathrm{ft}$. spread

Quantity

Retinospora plumosa aurea (Golden Japan Cypress). $1 \mathrm{ft}$. high. . . . . . $165 \ldots \ldots \ldots$ $4 \mathrm{ft}$. high, 3 to $4 \mathrm{ft}$. spread $5 \mathrm{ft}$. high, 4 to $6 \mathrm{ft}$. spread $6 \mathrm{ft}$. high, 5 to $7 \mathrm{ft}$. spread

$8 \mathrm{ft}$. high, 6 to $8 \mathrm{ft}$. spread

$10 \mathrm{ft}$. high, \& $\mathrm{ft}$. spread

$12 \mathrm{ft}$. high, $9 \mathrm{ft}$. spread

Retinospora squarrosa (Blue Japan Cypress). $1 \mathrm{ft}$. high $2 \mathrm{ft}$. high

$3 \mathrm{ft}$. high, 2 to $3 \mathrm{ft}$. spread

$5 \mathrm{ft}$. high, 4 to $5 \mathrm{ft}$. spread

$6 \mathrm{ft}$. high, $4 \frac{1}{2}$ to $6 \mathrm{ft}$. spread

$7 \mathrm{ft}$. high, 4 to $6 \mathrm{ft}$. spread

$8 \mathrm{ft}$. high, 4 to $6 \frac{1}{2} \mathrm{ft}$. spread

$9 \mathrm{ft}$. high, 6 to $7 \mathrm{ft}$. spread

$10 \mathrm{ft}$. high, 6 to $7 \mathrm{ft}$. spread

$16 \mathrm{ft}$. high, $9 \mathrm{ft}$. spread

Retinospora filifera (Thread-branched Japanese Cypress).

$3 \mathrm{ft}$. high, 2 to $3 \mathrm{ft}$. spread

$4 \mathrm{ft}$. high, 3 to $4 \mathrm{ft}$. spread

$5 \mathrm{ft}$. high, 4 to $5 \mathrm{ft}$. spread

Retinospora obtusa (Obtuse-leaved Japanese Cypress)

$4 \mathrm{ft}$. high, 3 to $4 \mathrm{ft}$. spread

$6 \mathrm{ft}$. high, 4 to $6 \mathrm{ft}$. spread

$10 \mathrm{ft}$. high, $5 \mathrm{ft}$. spread

Retinospora obtusa nana (Dwarf Obtuse-leaved Japanese Cypress). 6 to 12 in high

$1 \mathrm{ft}$. high.

$2 \mathrm{ft}$. high

$3 \mathrm{ft}$. high

$18 \ldots \ldots \ldots 450$

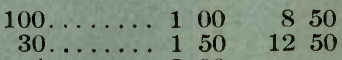

Spruce, White. Picea alba.

3 to 6 in. high, 3-yr. seedlings....Per $1,000, \$ 5 ;$ Per $10,000, \$ 40 \ldots 60,000$

4 to 12 in. high, 3-yr. transplanted ............ $1,000, \$ 40 \ldots 46,000 \ldots \ldots 08$

$1 \mathrm{ft}$. high, 4 yrs. .......................... $1,000, \$ 90 \ldots 2,000 \ldots \ldots \ldots .15$

$1 \frac{1}{2} \mathrm{ft}$. high, 4 yrs. . . . . . . . . . . . . . . . . . . . . $1,000, \$ 125 \ldots 1,000 \ldots \ldots$

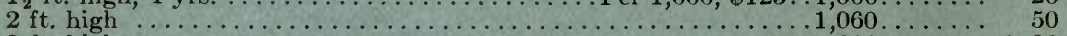

$3 \mathrm{ft}$. high

$4 \mathrm{ft}$. high, 2 to $3 \mathrm{ft}$. spread.

$5 \mathrm{ft}$. high, $2 \frac{1}{2}$ to $3 \frac{1}{2} \mathrm{ft}$. spread.

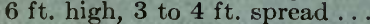

$7 \mathrm{ft}$. high

$8 \mathrm{ft}$. high, 4 to $5 \mathrm{ft}$. spread $\cdots$

$9 \mathrm{ft}$. high, 4 to $5 \frac{1}{2} \mathrm{ft}$. spread .

$10 \mathrm{ft}$. high, 4 to $6 \mathrm{ft}$. spread.

$12 \mathrm{ft}$. high, 5 to $7 \mathrm{ft}$. spread

$16 \mathrm{ft}$. high, $8 \mathrm{ft}$. spread .........

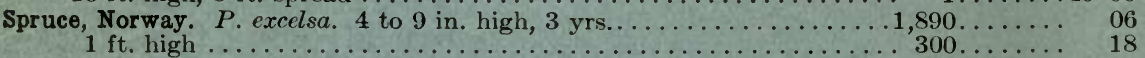

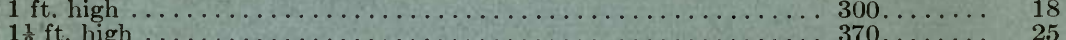

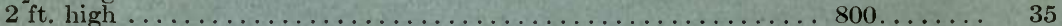

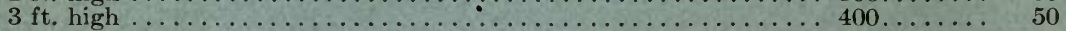

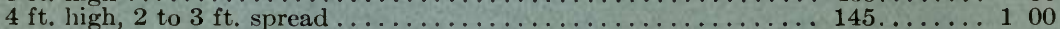

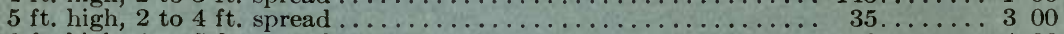

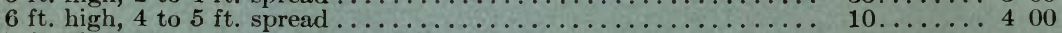

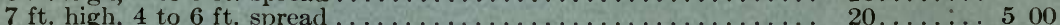

Spruce, Norway. $8 \mathrm{ft}$. high, 4 to $6 \mathrm{ft}$. spread $\ldots \ldots \ldots \ldots \ldots \ldots \ldots \ldots \ldots \ldots \ldots \ldots$

$10 \mathrm{ft}$ high, 7 to $9 \mathrm{ft}$, spread

$12 \mathrm{ft}$. high, 7 to $9 \mathrm{ft}$. spread

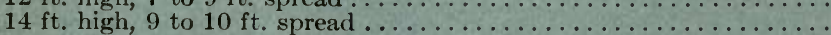

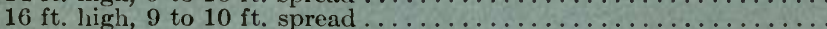

$18 \mathrm{ft}$. high, 9 to $11 \mathrm{ft}$. spread

$20 \mathrm{ft}$. high, 8 to $12 \mathrm{ft}$. spread

$22 \mathrm{ft}$. high, 10 to $12 \mathrm{ft}$. spread

(n)

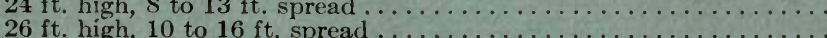

$2 s \mathrm{ft}$. high, $13 \mathrm{ft}$. spread

$30 \mathrm{ft}$. high, $14 \mathrm{ft}$. spread

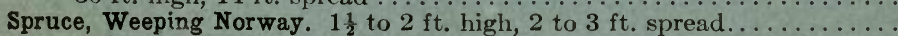

$3 \frac{1}{2} \mathrm{ft}$. high, $2 \frac{1}{2}$ to $3 \mathrm{ft}$. spread ....

$6 \mathrm{ft}$. high, $2 \frac{1}{2}$ to $3 \mathrm{ft}$. spread

$14 \mathrm{ft}$. high, $7 \mathrm{ft}$. spread.

Spruce, Maxwell's Dwarf Norway. P. excelsa, var. Maxwelli. $1 \mathrm{ft}$. high ...

Spruce, Gregory's Dwarf Norway. P. excelsa Gregoriana.

$9 \mathrm{in}$. high, $1 \mathrm{ft}$. spread

$1 \mathrm{ft}$. high, $1 \frac{1}{2} \mathrm{ft}$. spread
Each

$35 \ldots \ldots+500$

$60 \ldots \ldots 7700$

$15 \ldots \ldots 1200$

$10 \ldots \ldots \ldots 2000$

$1 \ldots \ldots \ldots 2500$

$35 \ldots \ldots \ldots 300$

$5 \ldots \ldots \ldots 500$

$30 \ldots \ldots .800$
$4 \ldots \ldots 1200$

$1 \ldots \ldots 2000$

$1 \ldots \ldots 2500$

$50 \ldots \ldots \ldots .40$

$10 \ldots \ldots 250$

$18 \ldots \ldots \ldots 500$

$30 \ldots \ldots 700$

$10 \ldots \ldots .900$

$3 \ldots \ldots: 1200$

$3 \ldots \ldots 1500$

$2 \ldots \ldots 2500$

$2 \ldots \ldots 3000$

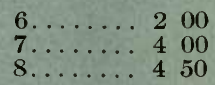

$15 \ldots \ldots 200$

$1: \ldots \ldots .1200$

1500 4000

$\begin{array}{ll}3 & 50 \\ 7 & 50\end{array}$

1750

4000

5500

7000

$4 \ldots \ldots \ldots 300$

$4 \ldots \ldots \ldots 400$

$600 \ldots \ldots \ldots 100$

$50 \ldots \ldots \ldots 200$

$40 \ldots \ldots \ldots 350$

$50 \ldots \ldots \ldots 500$

$20 \ldots \ldots 600$

$7 \ldots \ldots 1000$

$4 \ldots \ldots \ldots 1500$

$14 \ldots \ldots 3000$

$8 \ldots \ldots 3300$

$3 \ldots \ldots .3500$

$1 \ldots \ldots .4000$

$\begin{array}{ll}\text { Per } & 10 \\ \$ 15 & 00\end{array}$

2500

9000

300

2500

6500

3000

$15 \ldots \ldots \ldots 1400$

$10 \ldots \ldots 1800$

$3 \ldots \ldots 2000$

$9 \ldots \ldots 2500$

$6 \ldots \ldots 3000$

$6 \ldots \ldots \ldots 3500$

$6 \ldots \ldots 4000$

$7 \ldots \ldots .5000$

$2 \ldots \ldots .5500$

$1 \ldots \ldots 6000$

$1 \ldots \ldots 6500$

$3 \ldots \ldots \ldots 75$

$5 \ldots \ldots \ldots 100$

$3 \ldots \ldots \ldots 500$

$1 \ldots \ldots \ldots 1800$

$50 \ldots \ldots \ldots 100$

900

50

175

200

250

450

850

2500

3000

$40 \quad 00$

7000

12000

16000

$50 \ldots \ldots \ldots 90$

800

$30 \ldots \ldots \ldots 100$
400

1500

18 on

2000

3500
6500

60

1000

1500

$\begin{array}{ll}40 & 00 \\ 60 & 00\end{array}$ 


\section{EVERGREEN TREES, SPRUCE.}

Spruce, Alcock's. P. bicolor; syn., P. Alcockiana.

2 to 6 in. high, $3-y r$. seedlings

2 to 6 in. high, 3-yr. transplanted

$2 \mathrm{ft}$. high

$3 \mathrm{ft}$. high,

$4 \mathrm{ft}$. high, 2 to $3 \mathrm{ft}$. spread

$5 \mathrm{ft}$. high, 2 to $4 \mathrm{ft}$. spread

$7 \mathrm{ft}$. high, 4 to $5 \mathrm{ft}$. spread

Spruce, Oriental. $P$. orientalis. 6 to 12 in. high

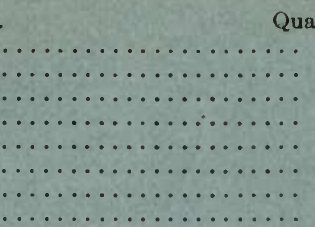

$1 \mathrm{ft}$. high

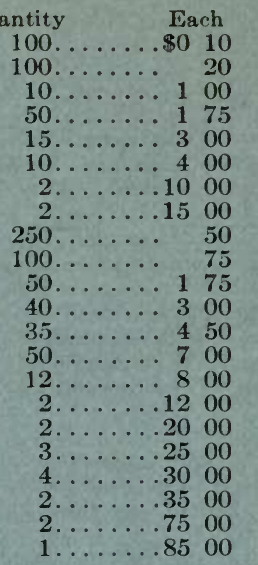

$2 \mathrm{ft}$. high

$4 \mathrm{ft}$. high, 2 to $4 \mathrm{ft}$. spread

$5 \mathrm{ft}$. high, 3 to $5 \mathrm{ft}$. spread

$6 \mathrm{ft}$. high, 5 to $6 \mathrm{ft}$. spread

$8 \mathrm{ft}$. high, $7 \mathrm{ft}$. spread

$10 \mathrm{ft}$. high, $6 \mathrm{ft}$. spread

$12 \mathrm{ft}$. high, 6 to $7 \mathrm{ft}$. spread

$14 \mathrm{ft}$. high, 6 to $7 \mathrm{ft}$. spread

$16 \mathrm{ft}$. high, 6 to $7 \mathrm{ft}$. spread

$20 \mathrm{ft}$. high, $8 \mathrm{ft}$. spread

$25 \mathrm{ft}$. high, $7 \mathrm{ft}$. spread

Spruce, Colorado Blue. P. pungens, var. glauca. Selected blue.
$1 \mathrm{ft}$. high
$2 \mathrm{ft}$. high
$3 \mathrm{ft}$. high
$4 \mathrm{ft}$. high, $2 \frac{1}{2}$ to $3 \frac{1}{2} \mathrm{ft}$. spread
$5 \mathrm{ft}$. high, 3 to $4 \mathrm{ft}$. spread
$6 \mathrm{ft}$. high, 3 to $4 \mathrm{ft}$. spread .
$9 \mathrm{ft}$. high, 5 to $6 \mathrm{ft}$. spread
$10 \mathrm{ft}$. high, 5 to $8 \mathrm{ft}$. spread
$14 \mathrm{ft}$. high, 7 to $9 \mathrm{ft}$. spread
$16 \mathrm{ft}$. high, $10 \mathrm{ft}$. spread
$18 \mathrm{ft}$. high, $11 \mathrm{ft}$. spread

Spruce, Colorado. $P$. pungens. Mixed, selected blue, medium blue and green

1 to 3 in. high, 2 yrs. .

3 to 10 in. high,.....

Medium blue and green. $1 \mathrm{ft}$. high

$2 \mathrm{ft}$. high.

$3 \mathrm{ft}$. high

$4 \mathrm{ft}$. high, 2 to $3 \mathrm{ft}$. spread

$5 \mathrm{ft}$. high, 3 to $4 \mathrm{ft}$. spread

$6 \mathrm{ft}$. high, 3 to $4 \mathrm{ft}$. spread

$7 \mathrm{ft}$. high, $4 \mathrm{ft}$. spread

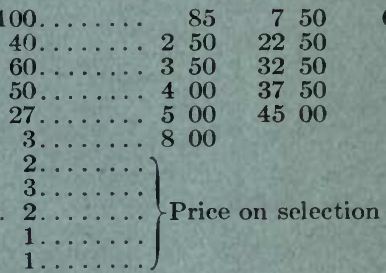

6000

$\begin{array}{llll}400 & 3500\end{array}$

600

5000

2200

4000

6000

7000

Per 100

$\$ 800$

1500

2000

3500

(1)

$14 \mathrm{ft}$. high, $7 \mathrm{ft}$. spread .

Spruce, Koster's Colorado Blue. P. pungens, var. glauca Kosterii. Grafted. 3 to 6 in. high.

$1 \frac{1}{2} \mathrm{ft}$. high

$2 \mathrm{ft}$. high $2 \frac{1}{2} \mathrm{ft}$. high

$3 \mathrm{ft}$. high, 2 to $3 \mathrm{ft}$. spread

$4 \mathrm{ft}$. high, 2 to $4 \mathrm{ft}$. spread

$5 \mathrm{ft}$. high, $2 \frac{1}{2}$ to $4 \mathrm{ft}$. spread

$6 \mathrm{ft}$. high, 3 to $4 \mathrm{ft}$. spread

$7 \mathrm{ft}$. high, $4 \mathrm{ft}$. spread

. Per 1,000, \$45. .2,700

700
380
245
100

100.
45

50.

30 .

20 .

$3 \ldots \ldots 2500$

$\begin{array}{ll} & 08 \\ 50 \\ \\ 75 \\ 1 & 50 \\ 2 & 00 \\ 3 & 00 \\ 3 & 50 \\ 5 & 00 \\ 6 & 00 \\ 25 & 00\end{array}$

75

400

450

1000

1750

2500

3000

4000

500

55
5500

4000

8000

ft. high, $6 \mathrm{ft}$. spread

$310 \ldots \ldots, 30$

275

900

2500

$50 \ldots \ldots \ldots 250$

$60 \ldots \ldots .300$

2000

2500

3500

$45 \ldots \ldots \ldots .700 \quad 6000$

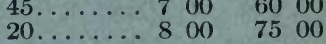

$12 \mathrm{ft}$. high, $6 \mathrm{ft}$. spread

$7 \ldots \ldots 1500$

$3 \ldots \ldots 2500$

$1 \ldots \ldots \ldots\}$ Price on application

Spruce, Omorika. $2 \mathrm{ft}$. high

$3 \mathrm{ft}$. high, $\ldots . . .$.

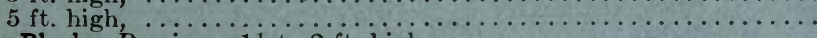

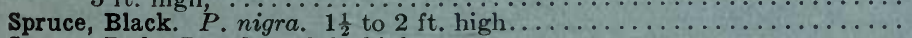

Spruce, Red. P. rubra. $2 \mathrm{ft}$. high

Spruce, Engelmann's. P. Engelmanni.

3 to 6 in. high ........................ $1,000, \$ 80,000$

Per $1,000, \$ 100.2,000$

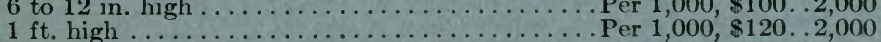

900.

$0 \ldots \cdots, 75$

$17 \ldots \ldots \ldots 150$

$75 \ldots \ldots \cdots 30$

600

1000

250

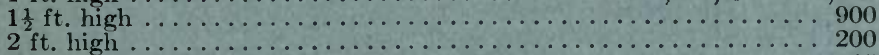

45

$3 \mathrm{ft}$. high

10.

$4 \mathrm{ft}$. high, 2 to $3 \mathrm{ft}$. spread

$11 \mathrm{ft}$. high, $5 \mathrm{ft}$. spread

$1 \ldots \ldots .5000$

$15 \mathrm{ft}$. high, $8 \mathrm{ft}$. spread

$1 \ldots \ldots 7000$

Spruce, Tiger Tail. $P$. polita. $i$ to 3 in. high, 3 -yr. seedlings. $\ldots \ldots \ldots \ldots 400$

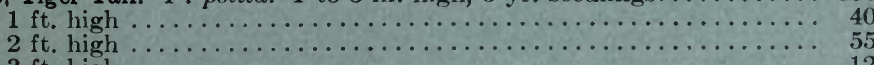

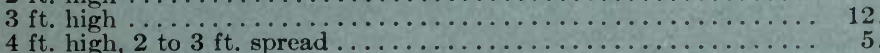

$4 \mathrm{ft}$. high, 2 to $3 \mathrm{ft}$. spread

Spruce, Douglas. Pseudotsuga Douglasii.
2 to 6 in. high, 2-yr. seedlings....Per 1,000, $\$ 10$; per 10,000, $\$ 90 \ldots 33,000$

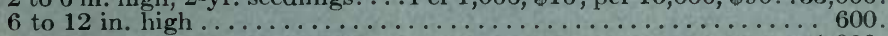

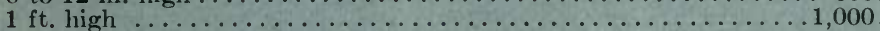

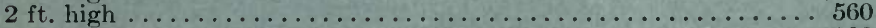

$3 \mathrm{ft}$. high

125 .

10

100

200

300

120

1 So

200

350

1250

3500

5000

1000

1500

1800

3000

10000

$4 \mathrm{ft}$. high, 2 to $3 \mathrm{ft}$. spread.

90

800

$\begin{array}{ll}3 & 00 \\ 7 & 50\end{array}$

1500 
FLOWERING-SHRUBS, SPRUCE to AZALEA.

Spruce, Douglas. $5 \mathrm{ft}$. high, $2 \frac{1}{2}$ to $4 \mathrm{ft}$. spread $6 \mathrm{ft}$. high, 4 to $5 \mathrm{ft}$. spread $7 \mathrm{ft}$. high

$8 \mathrm{ft}$. high, $\ddot{4}$ to $6 \mathrm{ft}$. spread

$10 \mathrm{ft}$. high, 5 to $7 \mathrm{ft}$. spread

$14 \mathrm{ft}$. high, 8 to $11 \mathrm{ft}$. spread

Yew, Japanese. Taxus cuspidata. 3 to $6 \mathrm{in.} \mathrm{high}$

6 to 12 in. high.

$1 \mathrm{ft}$. high

$3 \mathrm{ft}$. high, 2 to $3 \mathrm{ft}$. spread

Yew, Japanese. T. cuspidata, var. capitata. Upright-growing.

$1 \mathrm{ft}$. high $\because \ldots \ldots$ high, $1 \frac{1}{2}$ to $2 \mathrm{ft}$. spread
$3 \mathrm{ft}$. high, $2 \frac{1}{2}$ to $3 \mathrm{ft}$. spread

$4 \mathrm{ft}$. high, $2 \frac{1}{2}$ to $31 \mathrm{ft}$. spread

Yew, Dwarf-growing. T. cuspidata, var. brevifolia.

$1 \mathrm{ft}$. high

$1 \frac{1}{2} \mathrm{ft}$. high

$2 \mathrm{ft}$. high, 1 to $1 \frac{1}{2} \mathrm{ft}$. spread

$2 \frac{1}{2} \mathrm{ft}$. ligh, 2 to $2 \frac{1}{2} \mathrm{ft}$. spread

Yew Spreading. T. repandens, 6 in. high

$1 \mathrm{ft}$. high

$1 \mathrm{ft}$. high, $1 \mathrm{ft}$. spread.

$1 \mathrm{ft}$. high, $1 \frac{1}{2} \mathrm{ft}$. spread

$1 \mathrm{ft}$. high, $2 \mathrm{ft}$. spread

$2 \mathrm{ft}$. high, $2 \frac{1}{2} \mathrm{ft}$. spread

$2 \frac{1}{2} \mathrm{ft}$. high, $3 \mathrm{ft}$. spread

Yew, English. T. baccata.

$2 \frac{1}{2}$ to $3 \frac{1}{2} \mathrm{ft}$. high, $1 \frac{1}{2} \mathrm{ft}$. spread

$7 \mathrm{ft}$. high, 7 to $11 \mathrm{ft}$. spread .

$8 \mathrm{ft}$. high, $11 \mathrm{ft}$. spread

Yew, Golden English. T. Baccata, var. elegantissima.

$1 \mathrm{ft}$. high, 2 to $3 \mathrm{ft}$. spread

$2 \mathrm{ft}$. high, 1 to $2 \mathrm{ft}$. spread

$3 \mathrm{ft}$. high, 2 to $3 \frac{1}{2} \mathrm{ft}$. spread

$4 \mathrm{ft}$. high, 3 to $4 \mathrm{ft}$. spread .

$5 \mathrm{ft}$. high, 4 to $5 \mathrm{ft}$. spread

Yew, Canadian. T. Canadensis.

6 to $12 \mathrm{in.} \mathrm{high,} 6$ to 12 in. spread.

$1 \mathrm{ft}$. high, 2 to $4 \mathrm{ft}$. spread

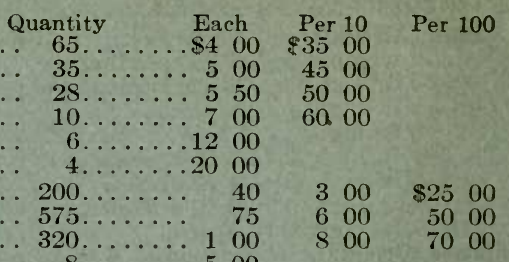

1250

2000

4500

1500

2000

2500

600

1500

2250

2750

4500

$30 \ldots \ldots 500$

$3 \ldots \ldots 8800$

$2 \ldots \ldots 1000$

$15 \ldots \ldots \ldots 150$

$3 \ldots \ldots 1200$

1250

5000

14000

$1 \ldots \ldots .3500$

$50 \ldots \ldots \ldots 100$

$20 \ldots \ldots \ldots 250$

$14 \ldots \ldots \ldots 500$

$10 \ldots \ldots 700$

$12 \ldots \ldots 80^{\circ}$

750

2000

4000

6000

7000

$300 \ldots \ldots \ldots \quad 50 \quad 400$

$30 \ldots \ldots 250 \quad 1750$

3000

\section{Flowering-Shrubs}

Althæa (Rose of Sharon; Hibiscus Syriacus), Double White, var. Jean d'Arc.

$1 \mathrm{ft}$. high

Quantit

50 Each

Per 10

$\$ 150$

225

$3 \mathrm{ft}$. high

$150 \ldots \ldots \ldots 25$

$15 \ldots \ldots \ldots$

300

150

200

$2 \mathrm{ft}$. high

Althæa, Double Red and White. $2 \mathrm{ft}$. high

$30 \ldots \ldots \ldots .25$

$\begin{array}{lll}30 \ldots \ldots \ldots & 25 \\ 50 \ldots \ldots & 25\end{array}$

$60 \ldots \ldots \ldots$

$25 \ldots \ldots \ldots \quad 30$

$2 \mathrm{ft}$. high

$3 \mathrm{ft}$. high

225

125

250

300

Aralia spinosa. See Hercules' Club.

Azalea, Flame. Azalea lutea; syn., calendulacea. $1 \mathrm{ft}$. high............ $1 \frac{1}{2} \mathrm{ft}$. high

$2 \mathrm{ft}$. high

$3 \mathrm{ft}$. high

$5 \mathrm{ft}$. high

Azalea, Ghent. A. pontica. Named Varieties-General Trauff (violet-red)

Mina Van Houtte (soft red), Narcissiflora yellow), Daviesi (white),

Perfecta (orange-red), Beauty Celeste (salmon-red), Sang de Gentbrugge (red), Deep Blood-Red, Violet-Red, Red, Raphael de Smet (white, rose-tinted), Grandeur Triomphante (violet-red), Coeeinea speciosa (orange-red), Bouquet de Flore (soft pink)

$1 \frac{1}{2} \mathrm{ft}$. high

$2 \mathrm{ft}$. high

$60 \ldots \ldots \ldots 75$

$60 \ldots \ldots \ldots 125$

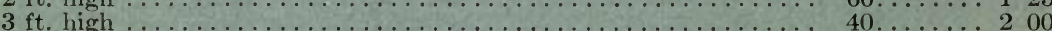

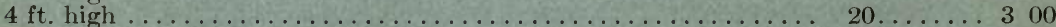

Azalea, Ghent. A. pontica. Mixed Varieties. $1 \frac{1}{2} \mathrm{ft}$. high $\ldots \ldots \ldots \ldots \ldots$ $2 \mathrm{ft}$. high

$20 \ldots \ldots$
$250 \ldots \ldots$

400

600

850

1400

1500

Per 100

$\$ 1200$

2000 $3 \mathrm{ft}$. high $4 \mathrm{ft}$. high

$\begin{array}{ll}350 \ldots \ldots & 60 \\ 100 \ldots \ldots & 75\end{array}$

$100 \ldots \ldots+100$

$30 \ldots \ldots .50$

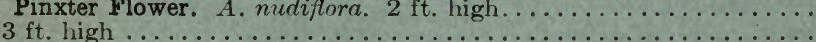

Azalea, Southern. A. vaseyi. $2 \mathrm{ft}$. high $\ldots \ldots \ldots \ldots \ldots \ldots \ldots \ldots \ldots \ldots$

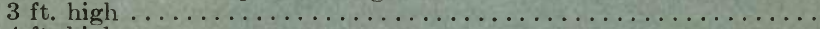

$4 \mathrm{ft}$. high

$5 \mathrm{ft}$. high

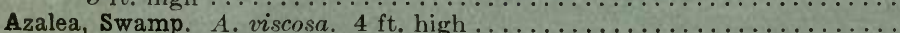

$5 \mathrm{ft}$. high

600

5000

$\begin{array}{lll}10 & 00 & 7500\end{array}$

1500

$22 \quad 25$

350

500

650

$\begin{array}{lll}9 & 00\end{array}$

400

500

800

$20 \ldots$

$20 \ldots \ldots \ldots 200$

$10 \ldots \ldots \ldots: 300$

1500

2500

3000

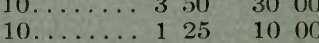

$18 \ldots \ldots \ldots 150$

3500

3000

4000

6000

1250 
FLOWERING SHRUBS. AZALEA to HAZELNUT.

Azalea arborescens. $2 \mathrm{ft}$. high $\ldots .$.

Quantity

$3 \mathrm{ft}$. high ...

$4 \mathrm{ft}$. high

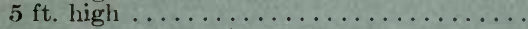

Azalea, Chinese. A. mollis. In variety. $1 \mathrm{ft}$. high

$1 \frac{1}{2} \mathrm{ft}$. high $\ldots \ldots \ldots \ldots \ldots$

Barberry, Common. Berberis vulgaris. $1 \mathrm{ft}$ high

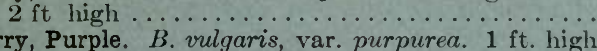

Barberry, Purple. B. vulgaris, var.
Barberry, Japanese. B. Thunbergii. 6 to $12 \mathrm{in.} \mathrm{high,} \mathrm{transplanted}$ $1 \frac{1}{2}$ to $2 \mathrm{ft}$. high $\ldots \ldots \ldots \ldots \ldots \ldots$

Bayberry (Wax Myrtle). Myrica cerifera. 2 to 4 in. high, 2-yr. trans. 480

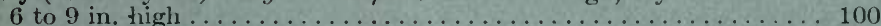
$1 \mathrm{ft}$. high

Button Bush. Cephalanthus occidentalis. 6 to 12 in. high $1 \frac{1}{2} \mathrm{ft}$. high

Calcicarpa Japonica. 6 to 12 in. high

Catalpa Bungei, Bush Form, Sheared Domes. $1 \mathrm{ft}$. high $2 \mathrm{ft}$. high

$3 \mathrm{ft}$. high, 3 to $4 \mathrm{ft}$. spread

$4 \mathrm{ft}$. high, 3 to $4 \mathrm{ft}$. spread

Corchorus Japonicus ; syn., Kerria Japonica. $1 \frac{1}{2} \mathrm{ft}$. high.

Deutzia crenata. $2 \mathrm{ft}$. high

$3 \mathrm{ft}$. high, $2 \mathrm{ft}$. spread

$4 \mathrm{ft}$. high, 3 to $4 \mathrm{ft}$. spread

$5 \mathrm{ft}$. high, 3 to $4 \mathrm{ft}$. spread

$6 \mathrm{ft}$. high, $4 \mathrm{ft}$. spread

Deutzia gracilis. $1 \frac{1}{2} \mathrm{ft}$. high

Deutzia Lemoine. 6 to $9 \mathrm{in.} \mathrm{high}$

$2 \mathrm{ft}$. high

Deutzia, Pride of Rochester. 9 to 15 in. high $2 \mathrm{ft}$. high

$3 \mathrm{ft}$. high, $2 \mathrm{ft}$. spread

$4 \mathrm{ft}$. high, $2 \mathrm{ft}$. spread

$5 \mathrm{ft}$. high

$6 \mathrm{ft}$. high

Dogwood, Red-twigged. Cornus alba. 6 to 12 in. high

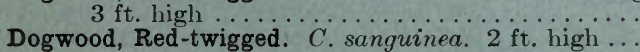

Dogwood, Panicled. $C$. paniculata. $3 \mathrm{ft}$. high. $4 \mathrm{ft}$. high. ... paniculata. 3 ft. high ................. 100 $6 \mathrm{ft}$. high

Elder, Marsh (Groundsel Bush). Baccharis halimifolia. 4 to 12 in. high... $3 \mathrm{ft}$. high

Elæagnus umbellatus (Silver Thorn).

1 to 3 in. seedlings

6 to $12 \mathrm{in.} \mathrm{high.}$

$1 \mathrm{ft}$. ligh

$2 \mathrm{ft}$. high

$3 \mathrm{ft}$. high Elæagnus longipes. $2 \mathrm{ft}$. high

Exochorda grandiflora (Pearl Bush). 1 to 3 in. high $1 \mathrm{ft}$. high $2 \mathrm{ft}$. high

Forsythia Fortunei (Golden Beli). $3 \mathrm{ft}$. high $4 \mathrm{ft}$. high.

Forsythia suspensa (Golden Bell) 6 to 12 in i igh $1 \mathrm{ft}$. high

$2 \mathrm{ft}$. high

$3 \mathrm{ft}$. high

$4 \mathrm{ft}$. high

$6 \mathrm{ft}$. high

Forsythia viridissima (Golden Bell) $1 \mathrm{ft}$. high

$2 \mathrm{ft}$. high.

$3 \mathrm{ft}$. high

$4 \mathrm{ft}$. high, 4 to $5 \mathrm{ft}$. spread

$5 \mathrm{ft}$. high, $5 \mathrm{ft}$. spread

Per $1,000, \$ 8, .2,100$

$150 \ldots \ldots \ldots$

100

220

50

12

475

125

15

100

35

Per $1,000, \$ 40.2,000$

500

1,000

200

160

200

70

40

100

Fringe, White. Chionanthus Virginica.

4 to $12 \mathrm{in}$. high, 3-yr. seedlings

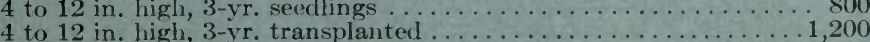

$2 \mathrm{ft}$. high...

$5 \mathrm{ft}$. high

$6 \mathrm{ft}$. high

$8 \mathrm{ft}$. ligh

$16 \mathrm{ft}$. high

Hazelnut, American. Corylus Americana

2 to 4 in. high secrlings.

10 $\mathrm{ft}$. high, $\mathrm{S} \mathrm{ft}$. spread
Each

100

150

200

40

60
00

10

25

10

10

12

20

15

20

15

20

30
40

40
50

20

20

25
30

30
35

40

25

20

10

15

18

30
35

35
40

12

25

15

30

1500

300

500

800

90

200

90

80

110

140

100

120

150

75

100

150

125

150

250

300

350

180

180

200

225

2 50

300

200

100

180

80

125

150

2 2.5

250

$\begin{array}{ll}3 & 00 \\ 1 & 00\end{array}$

$\begin{array}{ll}2 & 00 \\ 1 & 25\end{array}$

$\begin{array}{ll}1 & 25 \\ 2 & 50\end{array}$

200

$\begin{array}{ll}2 & 25\end{array}$

350

90

250

25

100

120

175

200

450

100

150

250

225

250

60

70

100

150

250

400

60

120

150

200

500

3000

50

80
200

350

500

Per 100

4500

50 00

9000

$27 \quad 50$

4000

7500

800

600

1000

1200

800

1000

500

800

2000

2500

1500

1500

2000

2500

1500

$\mathrm{S} 00$

600

1000

1200

1500

800

1800

1000

1800

2000

2500

800

100

800

1000

1500

800

1200

2000

500

600

800

1200

2000

500

300

500

60
-50

1500

100 
FLOWERING-SHRUBS, HERCULES' CLUB to MAPLE.

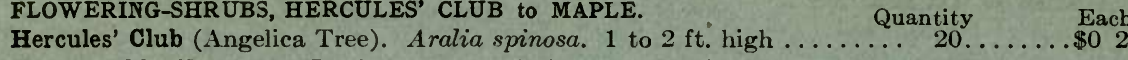

$5 \mathrm{ft}$. high

$6 \mathrm{ft}$. high

Horse-Chestnut, Dwarf. Esculus parviflora; syn., E. macrostachya

$1 \mathrm{ft}$. high

$1 \frac{1}{2} \mathrm{ft}$. high

$2 \mathrm{ft}$. high

Huckleberry, High-Bush. Vaccinium corymbosum. $2 \mathrm{ft}$. high. $4 \mathrm{ft}$. high

Hydrangea paniculata grandiflora. $2 \mathrm{ft}$. high $3 \mathrm{ft}$. high

Hydrangea paniculata. $2 \mathrm{ft}$. high. $2 \frac{1}{2} \mathrm{ft}$. high, $2 \frac{1}{2} \mathrm{ft}$. spread

$3 \mathrm{ft}$. high

$5 \mathrm{ft}$. high

$6 \mathrm{ft}$. high

Hydrangea Hortensis, var. Otaksa. 6 to 12 in. high

$1 \mathrm{ft}$. high, 3 yrs.

$2 \mathrm{ft}$. high

Hydrangea radiata $4 \mathrm{ft}$. high.

Hydrangea, Oak-leaved. H. quercifolia. $1 \mathrm{ft}$. high

Hydrangea arborescens grandiflora. 8 to 12 in. high, 2 yrs.

nex monticolor. $3 \mathrm{ft}$. high.

$5 \mathrm{ft}$. high

Indian Currant (Coral Berry). Symphoricarpus vulgaris.

1 to $1 \frac{1}{2} \mathrm{ft}$. high

$2 \mathrm{ft}$. high

$3 \mathrm{ft}$ high Judas, Japan, Cercis Japonica; syn., C. Chinensis. $1 \frac{1}{2} \mathrm{ft}$. high.

Laburnum vulgare (Golden Chain). $2 \mathrm{ft}$. high

Lilac. Syringa vulgaris. Named Varieties, as follows: Charles X, Bleantre Emile Liebig, Ludwig Spaeth, President Massart, Emile Lemoine, Mathieu Dombasle, Frau Dammann, Senator Volland, Insigna rubra,

Jules Finger, Belle de Nancy, Ville de Troyes, Mme. Lemoine,

President Grevy, Pyramidalis, Virginity, Mme. Casimir Perier.

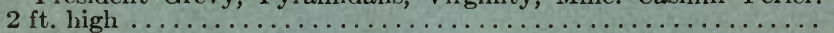

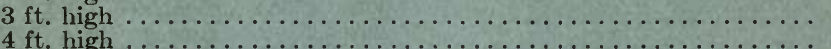

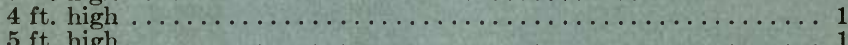

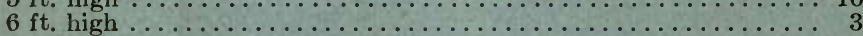

$500 \ldots \ldots \ldots 15$

$300 \ldots \ldots 25$

$200 \ldots \ldots \quad 30$

$100 \ldots \ldots \ldots 50$

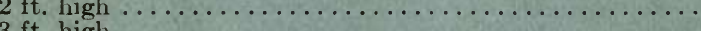

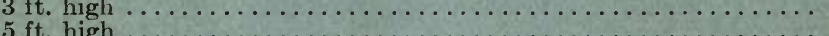

Lilac, White. $S$. vulgaris, var. alba. $2 \mathrm{ft}$. high $\ldots \ldots \ldots \ldots \ldots \ldots \ldots \ldots$

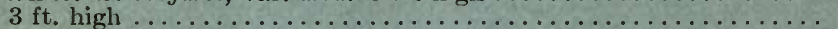

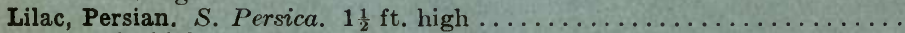

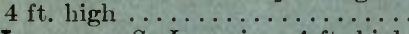

Lilac, Japanese. S. Japonica. $4 \mathrm{ft}$. high

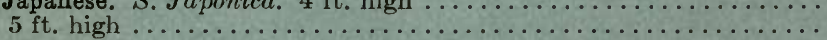

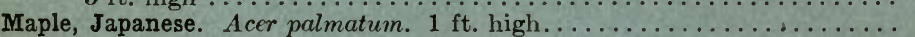

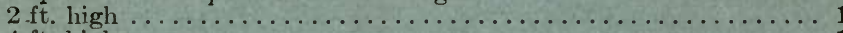

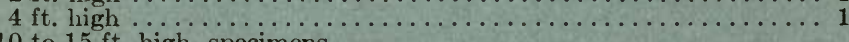

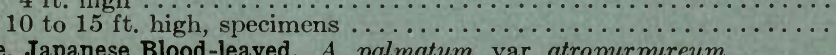

Maple, Japanese Blood-leaved. A. palmatum, var. atropurpureum.

$1 \mathrm{ft}$. higl

$2 \mathrm{ft}$. high

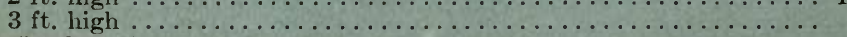

Maple, Cut-leaved Purple Japanese. A. palmatum, var. dissectum; ornatum

syn., dissectum atropurpureum. $1 \mathrm{ft}$. high................ $2 \mathrm{ft}$. high

$3 \mathrm{ft}$. high

Maple, Japanese Cut-leaved Green. A. palmatum, var. dissectum.

$1 \mathrm{ft}$ high

$2 \mathrm{ft}$. high

Maple, Japanese Golden. A. Japonicum, var. aurea. $2 \frac{1}{2} \mathrm{ft}$. high
Per 10

$\$ 200$

100

200

200

$\begin{array}{lll}1 & 00\end{array}$

180

200

150

250

100

180

350

100

150

180

200

250

$70 \ldots \ldots \quad 30$

$190 \ldots \ldots \ldots .40$

$130 \ldots \ldots 66$

$100 \ldots \ldots \ldots 75$

$30 \ldots \ldots 100$

Per 100

$\$ 800$

800

1500

S 00

1500

3000

800

1200

1500

1800

300

350

450

150

1200

200

120

$\begin{array}{ll}2 & 00 \\ 2 & 50\end{array}$

250

300

400

300

$\begin{array}{lll}5 & 00\end{array}$

800

200

250

250

500

90
120

$\begin{array}{ll}1 & 20 \\ 1 & 50\end{array}$

200

250

200

600

900

1500

200

375

500

700

800

120

200

250

400

250

350

200

400

250

400

160

250

350

1500

2000 3000

$6 \ldots \ldots$ Price on selection.

3500

$\begin{array}{ll}45 & 00 \\ 60 & 00\end{array}$

1000

1800 .

2000

3500

$\begin{array}{ll}6 & 00\end{array}$

800

1400

7500

900

1750

$30 \ldots \ldots \ldots 200$

$5 \ldots \ldots .400$

$50 \ldots \ldots 100$

800 
FLOWERING SHRUBS, MAPLE to SPIRAA

Maple, 'lartarian. A. ginnala; syn., A. Tataricum.

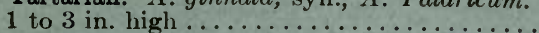

$2 \mathrm{ft}$ high

Per $1,000, \$ 8 \ldots 2,000 \ldots \ldots \ldots \$ 0$

$\ldots \ldots \ldots 200 \ldots \ldots 20$

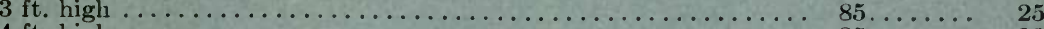

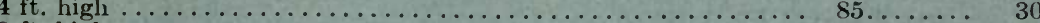

Orange, Hardy. Citrus trifoliata. 6 to 12 in. high.

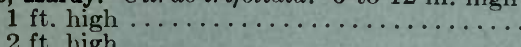

$2 \mathrm{ft}$. high

Plum, Beach. Prunus maritima. 8 in. high

$12 \ldots \ldots \ldots 100$

$1 \mathrm{ft}$. high

$600 \ldots \ldots$ os

$200 \ldots \cdots \cdots$

$2 \mathrm{ft}$. high

Privet, Ibota Ligustrum Ibota. 4 to 8 in. high

$2 \mathrm{ft}$. high

$3 \mathrm{ft}$. high

$4 \mathrm{ft}$. high

$5 \mathrm{ft}$. high

$6 \mathrm{ft}$. high

Privet, California. $L$. ovalifolium.

4 to 12 in. high

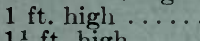

$1 \frac{1}{2} \mathrm{ft}$. high

$2 \mathrm{ft}$. high

$3 \mathrm{ft}$. high

$4 \mathrm{ft}$. high

$5 \mathrm{ft}$. high

Privet, Prostrate. L. Ibota, var. Regelianum

4 to 6 in. high

1 ft. high

$2 \mathrm{ft}$. high, $2 \frac{1}{2}$ to $3 \mathrm{ft}$. spread

$3 \mathrm{ft}$. high, 3 to $4 \mathrm{ft}$. spread.

$4 \mathrm{ft}$. high, 3 to $5 \mathrm{ft}$. spread

$\begin{array}{ll}100 \ldots \ldots & 25 \\ 100 \ldots \ldots & 30\end{array}$

$120 \ldots \ldots \ldots$. 05

$150 \ldots \ldots \ldots 1$.

$80 \ldots \ldots \ldots \quad 20$

Per $1,000, \$ 35 \ldots 3,700 \ldots \ldots \ldots, \quad 08$

$\ldots \ldots \ldots \ldots \ldots . \ldots .1,000 \ldots \ldots .10$

Per $1,000, \$ 90$. 2,000

, 000

600
125

Privet, Ibota, Standard, or Tree Form. Tops flat. $3 \mathrm{ft}$ high $\ldots \ldots \ldots \ldots \ldots \ldots 70 \ldots \ldots$

Per $1,000, \$ 25 \ldots 6,500 \ldots \ldots \ldots \quad 03$

Per $1,000, \$ 30 \ldots 3,600 \ldots \ldots \ldots .05$

Per $1,000, \$ 35.10,000 \ldots \ldots \ldots$. 05

Per $1,000, \$ 40 \ldots 5,000$

Per $1,000, \$ 55 . .3,200$

300 $4 \mathrm{ft}$. high $5 \mathrm{ft}$. high

Per $1,000, \$ 120 \ldots 1,000$

2000

Privet, Standard California. Bay Tree Form

5 to $5 \frac{1}{2} \mathrm{ft}$. high, 2 to $5 \mathrm{ft}$. spread ...

6 to $6 \frac{1}{2} \mathrm{ft}$. high, 3 to $6 \mathrm{ft}$. spread .

7 to $8 \mathrm{ft}$. high, 3 to $6 \mathrm{ft}$. spread

220

250

1800

2000

2500

Privet, Dome-shaped Ibota. $3 \mathrm{ft}$. high, 2 to $3 \mathrm{ft}$. spread $4 \mathrm{ft}$. high, 2 to $4 \mathrm{ft}$. spread.

Privet, Dome-shaped California. $1 \mathrm{ft}$ high, 6 to 12 in spread . . . . . .

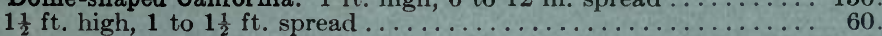

$2 \frac{1}{2} \mathrm{ft}$. high, 2 to $3 \mathrm{ft}$. spread

$3 \mathrm{ft}$. high, 2 to $4 \mathrm{ft}$. spread

$90 \ldots \ldots 250$

$5 \frac{1}{2} \mathrm{ft}$. high, $8 \mathrm{ft}$. spread. (See page 63 )

$55 \ldots \ldots 300$

$14 \ldots \ldots \$ 4-500$

$17 \ldots \cdots \cdots 500$

$50 \ldots \cdots \cdots$

$40 \ldots \cdots \cdots \quad 75$

$60 \ldots \ldots . \quad 40$

$25 \ldots \ldots 60$

$30 \ldots \ldots \ldots 75$

$8 \ldots \ldots 1200$

Privet, Pyramidal Ibota. $4 \mathrm{ft}$. high, 1 to $2 \frac{1}{2} \mathrm{ft}$. spread $5 \mathrm{ft}$. high, $1 \frac{1}{2}$ to $2 \mathrm{ft}$. spread. . $6 \mathrm{ft}$. high, 1 to $3 \mathrm{ft}$. spread

$7 \mathrm{ft}$. high, 2 to $3 \mathrm{ft}$. spread

Privet, Pyramidal California. $4 \mathrm{ft}$. high, $2 \mathrm{ft}$. spread $5 \mathrm{ft}$. high, $1 \frac{1}{2}$ to $3 \mathrm{ft}$. spread

$6 \mathrm{ft}$. high, 2 to $3 \mathrm{ft}$. spread...

Privet Arches, with double iron frame. $8 \mathrm{ft}$. high, $6 \mathrm{ft}$. wide $\ldots \ldots \ldots \ldots$

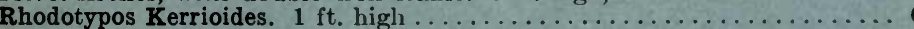

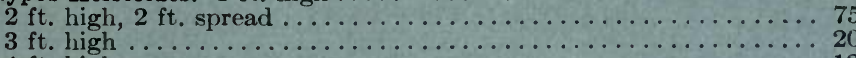

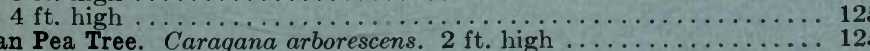

50
45 $\ldots \cdots \quad 75$

$60 \ldots \ldots \cdots+100$

$30 \ldots \ldots \ldots 100$

$20 \ldots \ldots \ldots 150$

$20 \ldots \ldots \ldots 150$

$20 \ldots \ldots 200$

$15 \ldots \ldots 1000$

$600 \ldots \ldots .10$

$750 \ldots \ldots+15$

20

25

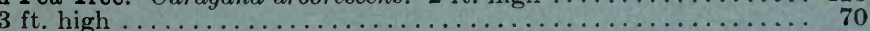

500

600

300

400

500

600

2500

$\begin{array}{rrrrr} & 80 & 5 & 00 \\ 1 & 20 & 8 & 00 \\ 1 & 50 & 12 & 00 \\ 1 & 80 & & 15 & 00 \\ 1 & 20 & & 10 & 00 \\ 2 & 50 & & 20 & 00 \\ 2 & 50 & & & \\ 2 & 25 & & 15 & 00\end{array}$

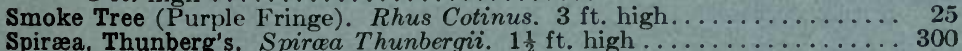

This is satisfactory all the year round. It is one of the first to bloom in the spring; bright red and orange foliage in the autumn. The numerous slender twigs have a ruddy color during the winter, which fills out satisfactorily the base of taller shrubs.

Spiræa, Bridal Wreath. S. prunifolia, var. flore pleno. $2 \mathrm{ft}$. high . $3 \mathrm{ft}$ high

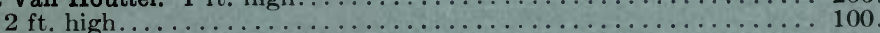

$3 \mathrm{ft}$. high

150

$4 \mathrm{ft}$. high is superior to the old-fashioned Bridal Wreath, being more

35 graceful in form and of better foliage.

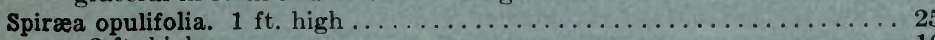

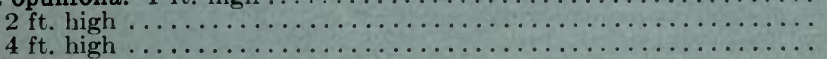

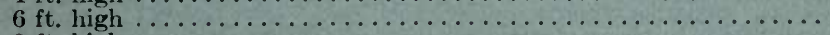

$8 \mathrm{ft}$. high . . . wishing a large bulk of foliage at low prices, the first year, $250 \ldots \ldots \ldots 08$ 
FLOWERING SHRUBS, VIBURNUM to BOX, TREE.

Viburnum Opulus, var. nanum. 4 to 8 in. high.

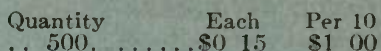

Per 100 $2 \mathrm{ft}$. high

These little plants grow but a few inches a year, and may be used to border garden paths instead of Boxwood. The plants may be divided up and spread out so the cost will be much less than the latter. It may also be used at the edge of a group of shrubs, as bordering a path where large-growing shrubs would spread out and get in the way.

Viburnum Opulus, var. sterile (Common Snowball). $3 \mathrm{ft}$. high..........

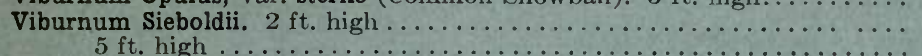

Viburnum tomentosum. $2 \mathrm{ft}$. high.

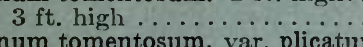

Viburnum tomentosum, var. plicatum (Japanese Snowbali). 2 ft. high $3 \mathrm{ft}$. high $\ldots \ldots \ldots \ldots \ldots \ldots \ldots \ldots$

$6 \mathrm{ft}$. high

$7 \mathrm{ft}$. high

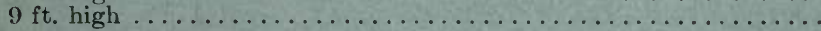

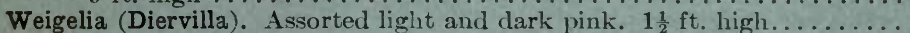

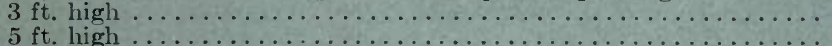

Weigelia florida rosea. 6 to 12 in. hig's.

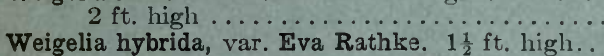

Weigelia, Yellow. Diervilla lonicera; syn., D. trifida. $3 \mathrm{ft}$. high $6 \mathrm{ft}$. high.

These plants, 6 feet high, are very wide and bushy, and at the price quoted will make a cheap mass of healthy, shining foliage, with interesting yellow flowers.

Weigelia, White. 6 to $12 \mathrm{in.} \mathrm{high}$ $3 \mathrm{ft}$. high ......... . . . . .

$25 \ldots \ldots 20$

$45 \ldots \ldots 250$
$4 \ldots \ldots 200$

$25 \ldots \ldots \ldots 20$

$75 \ldots \ldots \ldots 25$

$25 \ldots \ldots \ldots 20$

$100 \ldots \ldots \ldots 25$

$70 \ldots \ldots \ldots 35$

$15 \ldots \ldots \ldots 150$

5 . $\ldots 200$

S. ......... 300

$40 \ldots \ldots \ldots 15$

$20 \ldots \ldots \ldots 25$

20

300

$50 \ldots \ldots \ldots 15$

$18 \ldots \ldots \ldots 20$

$150 \ldots \ldots 12$

$80 \ldots \ldots \ldots \quad 15$

150

400

$1 \mathrm{s0}$

225

180

225

300

120

200

300

60

120

150

100

120

1000

S 00

$100 \ldots \ldots$ os

$20 \ldots \ldots \ldots 25$

$30 \ldots \ldots \ldots 15$

$60 \ldots \ldots \ldots 15$

60

180

120

120

Even in January or February this makes an interesting point in the landscape, for its silvery catkins glisten and shine in the sun. It is, therefore the first shrub to flower.

Witch Hazel. Hamamelis Virginiana.

2 to 6 in. high, 2 yrs.

6 to $9 \mathrm{in.} \mathrm{high}$

$1 \frac{1}{2} \mathrm{ft}$. high

$2 \mathrm{ft}$. high

This may be mixed with Pine and Hemlock to make a border plantation. It is a shrub that will not seriously damage the evergreens and will give that community of interest which is so welcomed by the evergreens. It is the latest of all autumn flowers and it shows best against the green background of the evergreens. In. November and early December, when all else in the garden is dormant, this surprises one with a delicate and stimulating perfume.

Yellow Root. Xanthorrhiza apiifolia. 6 to 12 in. high.

Long Island people have not learned to use this and other similar cover plants. We will some day learn that Privet and grass are not the two nearly exclusive types of landscape material. This shrub makes a thick mat about 2 feet high, covering the ground under trees and shrubs. 43

$1,050 \ldots \ldots \ldots$
$400 \ldots \ldots \ldots$
$40 \ldots \ldots$

\section{Broad-leaved Evergreen Shrubs}

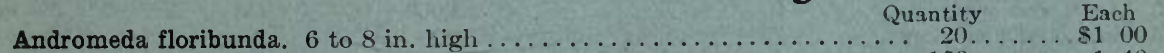

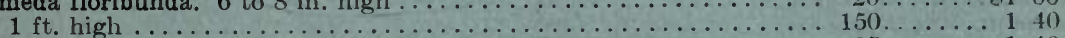

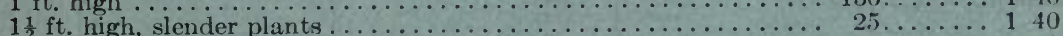

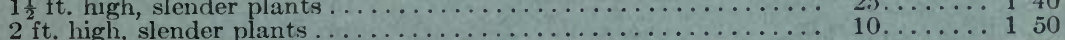

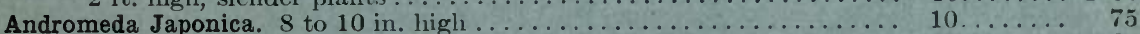

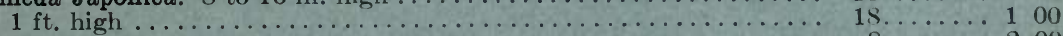

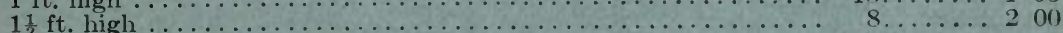

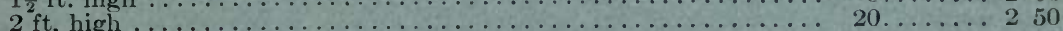

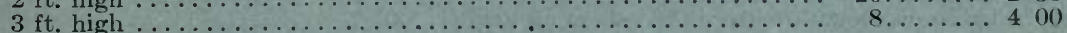

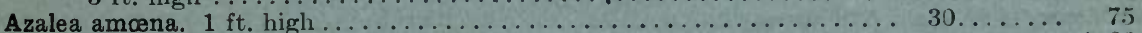

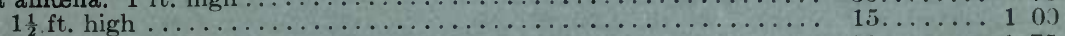

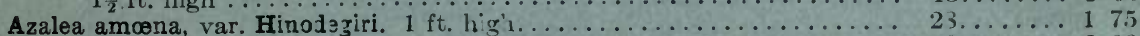

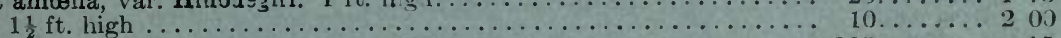

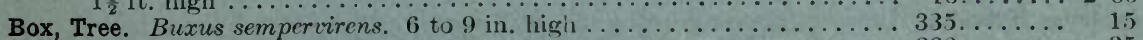

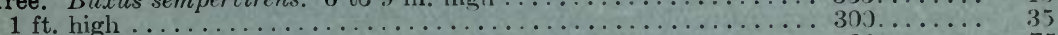

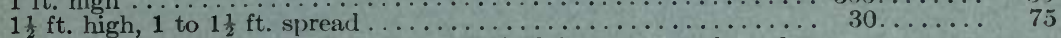

Box, Tree. Dome shape, trimined to hemispherical form, grown here 6 to

$$
12 \text { years. } 1 \frac{1}{2} \mathrm{ft} \text {. high }
$$

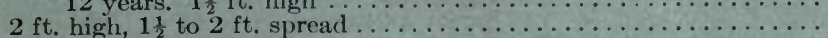

$2 \frac{1}{2} \mathrm{ft}$. high, $2 \mathrm{ft}$. spread

$3 \mathrm{ft}$. high, 2 to $4 \frac{1}{2} \mathrm{ft}$. spread

$3 \frac{1}{2} \mathrm{ft}$. high, 3 to $3 \frac{1}{2} \mathrm{ft}$. spread

$4 \mathrm{ft}$. high, $4 \mathrm{ft}$. spread

$10 \ldots \ldots 600$

$30 \ldots \ldots \ldots .9600$

$5 \ldots \ldots \ldots 1000$

$7 \ldots \ldots 1200$

$4 \ldots \ldots \ldots 1400$

$2 \ldots \ldots \ldots 1500$ 
BROAD-LEAVED EVERGREEN SHRUBS, BOX, TREE, to RHODODENDRON. $1 \mathrm{ft}$. high

$2 \mathrm{ft}$. high

$2 \frac{1}{2} \mathrm{ft}$. high

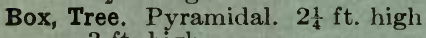

$3 \mathrm{ft}$. high

$3 \frac{1}{2} \mathrm{ft}$. high

$4 \frac{1}{2} \mathrm{ft}$. high

Box, Tree. B. sempervirens. Pyramidal. Imported 1909

$2 \frac{1}{2} \mathrm{ft}$. high

$4 \mathrm{ft}$. high.

$5 \mathrm{ft}$. high

Box, Tree. B. sempervirens. Tree form, or standard. Imported 1909.

$2 \mathrm{ft}$. stems, 15 in. spread .

Box, Tree. Tree form, or standard

$3 \frac{1}{2} \mathrm{ft}$. high, $15 \mathrm{in}$. spread.

$4 \mathrm{ft}$. high, 15 in. spread.

Quantity

$300 \quad$ Each

$50 \ldots \ldots 100$

$25 \ldots \ldots \ldots 225$

$13 \ldots \ldots \ldots 175$

$7 \ldots \cdots \cdots \cdots$

$17 \ldots \ldots 300$

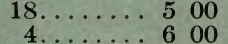

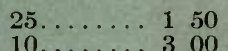

$6 . \ldots \ldots 500$

$15 \ldots \ldots \ldots 150$

1400

$8 \ldots \ldots 350$

$4 \ldots \ldots \ldots 450$

3200

Box, Dwarf (Box Edging). B. sempervirens, var. suffruticosa.

3 to 6 in. high

1 to $1 \frac{1}{2} \mathrm{ft}$. high

$4 \mathrm{ft}$. high, 4 to $5 \mathrm{ft}$. spread

Daphne Cneorum. 6 to 12 in. high

Euonymus radicans, Narrow-leaved Form

8 to 16 in. high

Euonymus radicans, var. reticulatus. White variegated form

Per $1,000, \$ 50 \ldots 3,000$

25

10

$5 \ldots \ldots 2000$

$40 \ldots \ldots 75$

$1,000 \ldots \ldots .08$

$40 \ldots \ldots \ldots \quad 25$

8 to 12 in. high

Euonymus radicans, var. vegętus. Broad-leaved form.

6 in. high

9 to 12 in. high

1 to $2 \mathrm{ft}$. high

$100 \ldots \ldots \quad 15$

$140 \ldots \ldots \ldots$

$750 \ldots \ldots 18$

$160 \ldots \ldots \ldots 20$

$60 \ldots \ldots .30$

$130 \ldots \ldots \ldots 75$

$150 \ldots \ldots \ldots 150$

$60 \ldots \ldots \ldots 250$

$-15 \ldots \ldots .400$

$15 \ldots \ldots 500$

$5 \ldots \ldots 6600$

$3 \mathrm{ft}$. high

$4 \mathrm{ft}$. high

$6 \mathrm{ft}$. high

400

600

60

$\begin{array}{ll}1 & 00 \\ 2 & 00\end{array}$

120

80
150

180

250

600

1250

2000

3000

4000

Holly, Japanese. Ilex crenata.

1 to 3 in. high, 3 yrs. ...................... $1,000, \$ 40 \ldots 2,000 \ldots \ldots 08$

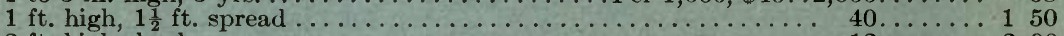

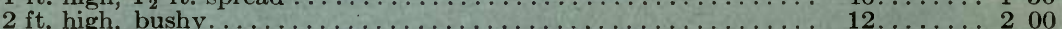

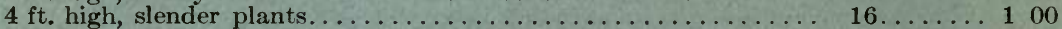

$6 \mathrm{ft}$. high, slender plants.

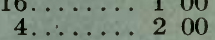

Laurel, Mountain. Kalmia latifolia. $1 \mathrm{ft}$ high $\ldots \ldots \ldots \ldots \ldots \ldots \ldots \ldots \ldots 400 \ldots \ldots \ldots$

$2 \mathrm{ft}$. high, $1 \frac{1}{2}$ to $2 \mathrm{ft}$. spread $\ldots \ldots \ldots \ldots \ldots \ldots \ldots \ldots \ldots \ldots \ldots \ldots \ldots \ldots \ldots \ldots \ldots \ldots \ldots \ldots \ldots$
$3 \mathrm{ft}$ high, 2 to $2 \frac{1}{2} \mathrm{ft}$. spread $\ldots \ldots \ldots \ldots \ldots \ldots \ldots \ldots \ldots \ldots$

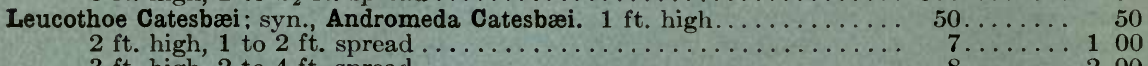

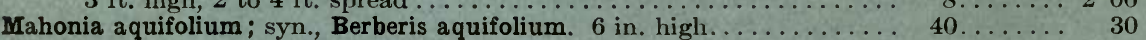

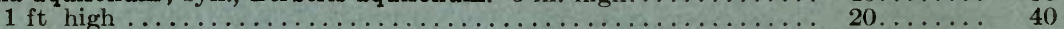

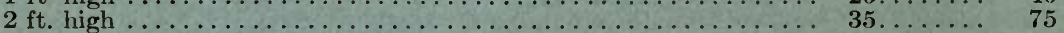

Mahonia Japonica; syn., Berberis Japonica. $1 \frac{1}{2} \mathrm{ft}$. high $\ldots \ldots \ldots \ldots \ldots \ldots \ldots, 25 \ldots \ldots \ldots \ldots$

Myrtle, Trailing Blue (Periwinkle). Vinca minor. 4 to 8 in. high.

Per $1,000, \$ 15 \ldots 10,000$

600

600

$\begin{array}{ll}5 & 00 \\ 7 & 00\end{array}$

1000

700

1200

1500

5000

10000

60

1400

1800

900

400

500

800

3500

400

7500

200

300

Myrtle, Purple, Double-flowered. $V$. minor, var. purpurea plena.

Large, solid clumps, 1 to $1 \frac{1}{2} \mathrm{ft}$. wide ................. $1,000, \$ 50 \ldots 2,700 \ldots \ldots$

Myrtle, White. V. minor, var. alba

Pachysandra terminalis. 3 to 6 in. high

$200 \ldots \ldots 20$

Rhododendron maximum. $3 \mathrm{ft}$. high

$1200 \ldots \ldots \ldots$

$\ldots \ldots \ldots 200$

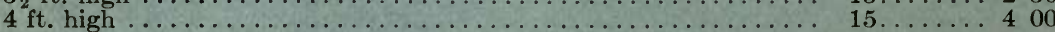

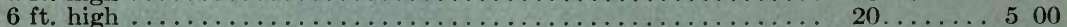

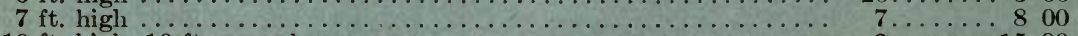

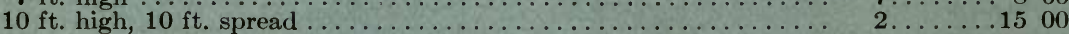

$12 \mathrm{ft}$. high, $12 \mathrm{ft}$. spread ............................ 2500

Write for prices in ear-load lots from the colleeting fields.

Rhododendron Catawbiense. $1 \mathrm{ft}$. high, $1 \mathrm{ft}$. spread ................. $750 \ldots$

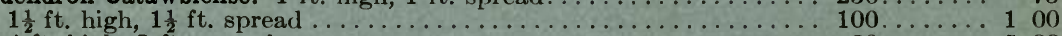

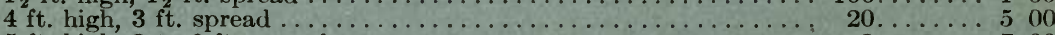

40

300

100

800

150

1800

2000

3500

4000

$5 \mathrm{ft}$. high, 3 to $6 \mathrm{ft}$. spread $\ldots$

Rhododendron Catawbiense Hybrids. These are plants growing in our Nursery in the open, fully exposed to sun and wind for one or more years, many of them five to twelve years.

Class $A-$

125 Album elegans, 2 to $6 \mathrm{ft}$. high.

6 Blandyanum, $4 \mathrm{ft}$. high.

6 Minnie, $3 \frac{1}{2}$ to $5 \mathrm{ft}$. high.

240 President Lincoln, 2 to $5 \mathrm{ft}$. high.

$1 \mathrm{ft}$. high

$1 \frac{1}{2} \mathrm{ft}$. high

$2 \mathrm{ft}$. high

25 Album grandiflorum, $2 \frac{1}{2}$ to $4 \mathrm{ft}$. high. 40 Giganteum, $1 \frac{1}{2}$ to $4 \mathrm{ft}$. high.

185 Parson's Gloriosa, $1 \frac{1}{2}$ to $4 \frac{1}{2} \mathrm{ft}$. high

Per 10 Per 100

8800

900

1000 
BROAD-LEAVED EVERGREEN SHRUBS, RHODODENDRON to ROSA RUGOSA.

Rhododendron, Catawbiense Hybrids (Class $A$ ), continued

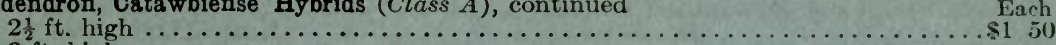

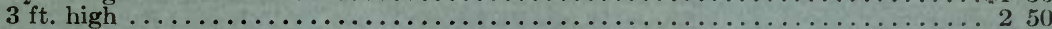

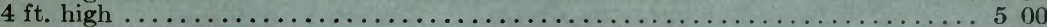

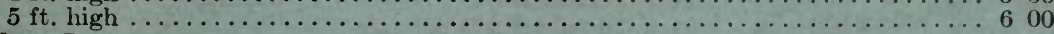

Per 10

$\$ 1250$

2000

4500

Class $B$

185 Caractacus, 1 to $3 \mathrm{ft}$. high.

150 Charles Bagley, $1 \frac{1}{2}$ to $3 \mathrm{ft}$. high .

$40 \mathrm{Lady}$ Armstrong, 1 to $3 \frac{1}{2} \mathrm{ft}$. high.

22 Purpureum grandiflorum, 2 to $2 \frac{1}{2} \mathrm{ft}$. high.

$1 \frac{1}{2} \mathrm{ft}$. high $\ldots \ldots \ldots \ldots \ldots \ldots \ldots \ldots$

2 ft. high

$2 \frac{1}{2} \mathrm{ft}$. high

$3 \mathrm{ft}$. high

$4 \mathrm{ft}$. high

Class $C$

125 Atrosanguineum, $1 \frac{1}{2}$ to $4 \frac{1}{2} \mathrm{ft}$. high.

18 Boule de Neige, $1 \frac{1}{2}$ to $3 \mathrm{ft}$. high.

85 Charles Dickens, $1 \frac{1}{2}$ to $3 \mathrm{ft}$. high.

30 Flushing, 2 to $4 \mathrm{ft}$. high.

15 Lady Claremont, $1 \frac{1}{2}$ to $4 \mathrm{ft}$. high.

90 Abraham Lincoln, $1 \frac{1}{2}$ to $3 \mathrm{ft}$. high.

$1 \mathrm{ft}$. high $\ldots \ldots \ldots \ldots \ldots \ldots \ldots \ldots \ldots \ldots$

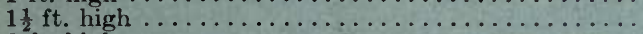

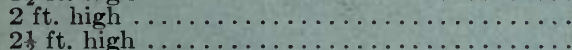

$3 \mathrm{ft}$. high

$4 \mathrm{ft}$. high

300 Roseum elegans, $1 \frac{1}{2}$ to $5 \mathrm{ft}$. high.

180 Everestianum, $1 \frac{1}{2}$ to $4 \mathrm{ft}$. high.

4 Madame Carvalho, $3 \frac{1}{2}$ to $4 \frac{1}{2} \mathrm{ft}$. high.

35 Purpureum elegans, 1 to $4 \frac{1}{2} \mathrm{ft}$. high.

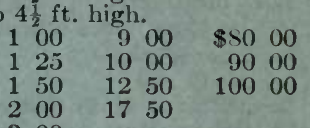

9 James Bateman, $2 \mathrm{ft}$. high.

90 Delicatissima, $1 \frac{1}{2}$ to $4 \frac{1}{2} \mathrm{ft}$. high.

130 General Grant, $1 \frac{1}{2}$ to $3 \mathrm{ft}$. high.

170 Parsons' Grandiflorum, $1 \frac{1}{2}$ to $4 \mathrm{ft}$. high.

$30 \mathrm{Mrs}$. Milner, $1 \frac{1}{2}$ to $2 \mathrm{ft}$. high.

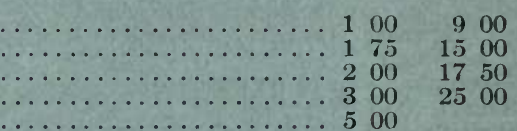

Rhododendron Catawbiense Hybrids.

Class $D$

15 H. H. Hunnewell, $1 \frac{1}{2} \mathrm{ft}$. high.

3 Henry Probasco, $2 \frac{1}{2}$ to $3 \mathrm{ft}$. high.

7 The Boss, 2 to $3 \mathrm{ft}$. high

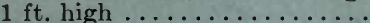

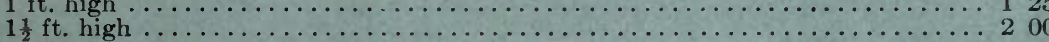

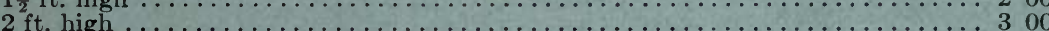

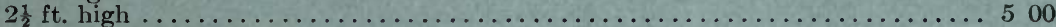

Plants Imported Spring of 1909 -
5 Album elegans.

40 Delicatissima.

15 Lady Claremont.

100 Charles Dickens.

50 James Bateman.

Prices for April and May, 1909: 12 to 15 inches and 15 to 18 inches high, $\$ 1$ each, $\$ 9.50$ for $10, \$ 85$ per 100

Plants Imported Spring of 1909; Rare, Hardy Varieties-

25 The Boss.

10 S. B. Parsons.

5 Blanche Superbe.

15 Kissena.

70 Mrs. Milner.

75 Parsons' Grandiflora.

$50 \mathrm{H}$. W. Sargent.

115 Lady Armstrong.
70 Atrosanguineum

15 Roseum elegans.

75 Kettledrum.

75 General Grant.
Per 100

4 Kettledrum, $1 \frac{1}{2}$ to $2 \frac{1}{2} \mathrm{ft}$. high.

$55 \mathrm{H}$. W. Sargent, $1 \frac{1}{2}$ to $3 \mathrm{ft}$. high.

28 Doctor Torrey, $2 \frac{1}{2} \mathrm{ft}$. high.

9000 
ROSA WICHURAIANA to ANEMONE.

Rosa Wichuraiana (Memorial Rose) and Wichuraiana Hybrids-

$\begin{array}{ll}\text { Lady Gay } & \text { Hiawatha } \\ \text { Dorothy Perkins } & \text { South Orange Perfection } \\ \text { Farquhar } & \text { Yellow Rambler }\end{array}$

Price 25 cts. each, $\$ 2$ for $10, \$ 18$ per 100

Crimson Rambler

Quantity

Baby Rambler

$150 \ldots \ldots \$ 25$

Rosa multiflora, $2 \frac{1}{2}$ to $4 \mathrm{ft}$. high

$100 \ldots \ldots 25$

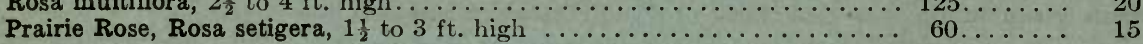

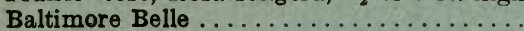

$\begin{array}{lll}60 & \ldots \ldots & 15 \\ 25 & \ldots \ldots & 30\end{array}$

Prairie Queen

Burnet Rose, Rosa spinosissima

$25 \ldots \cdots \cdots$

Wild Rose, Rosa nitida.

Sweet Brier, Rosa rubignosa

$45 \ldots \cdots, \quad 30$

75.

Jersey Beauty

Universal Favorite

Gardenia

Per 10

$\$ 200$

200

150

125

200

200

200

120

250

Per 100

$\$ 1800$

1800

1200

1000

\section{Vines}

Actinidia arguta. 4 to $6 \mathrm{ft}$. high. 7 to $9 \mathrm{ft}$. high

Akebia quinata. $2 \frac{1}{2}$ to $6 \mathrm{ft}$. high

Bitter Sweet, Japanese. Celastrus articulata. 1 to 2 ft. high 2 to $4 \mathrm{ft}$. high

Clematis Jackmani. 1 to $1 \frac{1}{2} \mathrm{ft}$. high

Clematis Henryi. 1 to $1 \frac{1}{2} \mathrm{ft}$. high.

Clematis paniculata. 1 to $2 \mathrm{ft}$. high, strong roots

Dutchman's Pipe. Aristolochia sipho. 2 to $3 \mathrm{ft}$. high. $8 \mathrm{ft}$. high $12 \mathrm{ft}$. high

Honeysuckle, Hall's Japanese. Lonicera Japonica, var. Halleana. 1 to $2 \frac{1}{\mathrm{ft}}$. high; 2 yrs. ...................... $1,000, \$ 40 \ldots 1,000 \ldots \ldots \ldots$

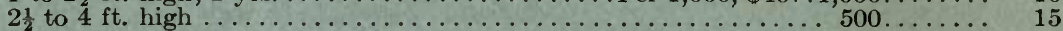

Honeysuckle Chinese. L. Japonica, var. Chinensis. 2 to $4 \mathrm{ft}$; 2 yrs. . . 200...... 15

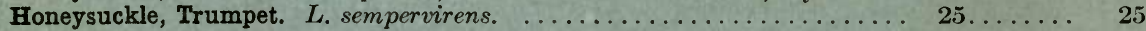

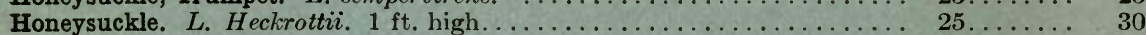

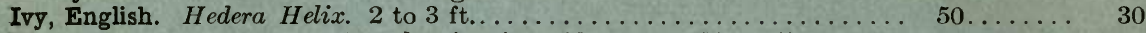

Ivy, Japanese, or Boston. Ampelopsis tricuspidata; syn Veitchii.

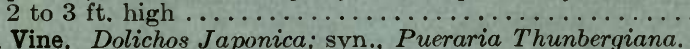

$400 \ldots \ldots 20$

Per 10

$\$ 400$

600

250

100

120

375

375

200

$\begin{array}{lll}4 & 00\end{array}$

Per 100

$\$ 800$

1000

1500

Kudzu Vine. Dolichos Japonica; syn., Pueraria Thunbergiana. . . . . . . $25 \ldots \ldots . .40$

Virginia Creeper. Ampelopsis quinquefolia.

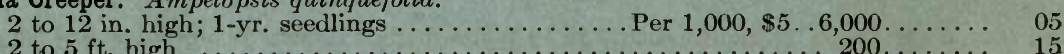
2 to $5 \mathrm{ft}$. high

15

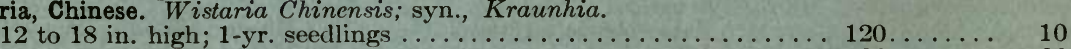

3 to $4 \mathrm{ft}$. high

$\begin{array}{ll}30 \ldots \cdots & 20 \\ 50 \ldots \cdots & 25 \\ & \ldots\end{array}$

$4 \mathrm{ft}$. high

$100 \ldots \ldots \ldots 30$

6 to $8 \mathrm{ft}$. high

$125 \ldots \ldots \ldots, 40$

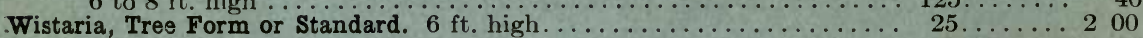

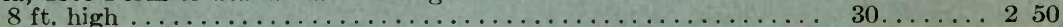

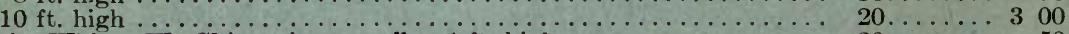

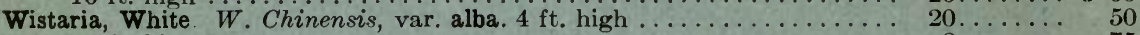
$6 \mathrm{ft}$ high

$8 \ldots \ldots+75$

6 ria, Japanese, or Loose-clustered. $W$. multiiuga. 6 to 12 in. high 2 to $3 \mathrm{ft}$. high.

4 to $5 \mathrm{ft}$. high

$7 \mathrm{ft}$. high

Wistaria speciosa, var. magnifica. Late-flowering. American. $6 \mathrm{ft}$ high. $8 \mathrm{ft}$. high $10 \mathrm{ft}$. high

$\begin{array}{rr}8 \ldots \ldots \ldots & 75 \\ 40 \ldots \ldots & 20 \\ 50 \ldots \ldots & 30 \\ 100 \ldots \ldots \ldots & 50 \\ 20 \ldots \ldots \ldots & 00 \\ 20 \ldots \ldots & 35 \\ 5 \ldots \ldots & 40 \\ \ldots & 6\end{array}$

80

120

120

200

250

200

180

350

150

20

120

100

80

150

180

250

$\begin{array}{lll}3 & 50\end{array}$

1500

2000

2500

400

180

250

350

800

250

$\begin{array}{lll}3 & 00\end{array}$

$\begin{array}{ll}3 & 00 \\ 5 & 00\end{array}$

600

1000

1000

1200

500

2000

3000

5000

\section{Hardy Garden Flowers}

Our plants are all field-grown, and are nearly all large clumps, larger than usually sold. Note also the low prices at which they are offered. This permits their use in large quantities for naturalizing, cover planting, and large groups in shrubberies. Lower rates on large quantities of our selection.

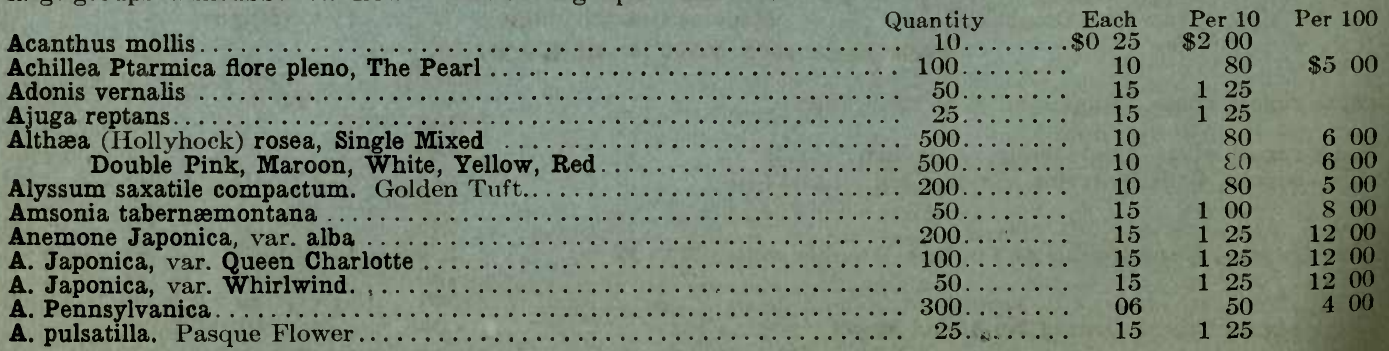


HARDY GARDEN FLOWERS, ANTHEMIS to FUNKIA.

Anthemis tinctoria. Chamomile; Golden Marguerite

............

A Canadensis.

A. chrysantha

A. chrysantha alba

A. nivea grandiflora

A. glandulosa

A., Mixed

A. alpina. Aip

Armeria plantaginea. Thrift, or Sea Pink.

Artemisia abrotanum. Southernwood; Old Man

Asclepias tuberosa. Butterfly Weed; Pleurisy Root.

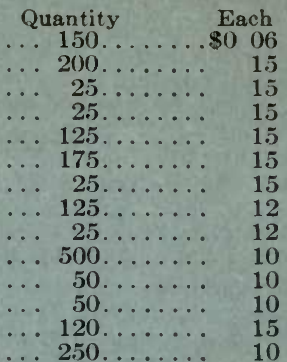

Per 10

$\$ 050$

125

12.5

125

125

125

125

100

100

180

80

80

125

Per 100

$\$ 400$

1000

1200

1200

800

500

5 00

Aster Novæe-A

250

1000

800

This stately plant is one of the latest in the garden. It grows
about 6 feet high, with a stiff stem that does not fall down, and bears large clusters of blue flowers. It is suitable for planting, both in the garden and amongst shrubs.

Bellis perennis. Double pink and white . . . . . . . . . . . . . 300

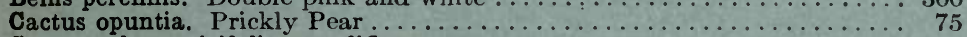

Campanula persicifolia grandiflora.

C. persicifolia gigantea, var. Mœrheimei

C. latifolia macrantha.

c. Carpatica. Carpathian Harebell

Centaurea macrocephala.

Cerastium tomentosum. Snow-in-Summer

Chrysanthemum, Pompon-

Anna Mary

Julia Lagravere

Princess Louise

St. Illoria.

Eagle d'Or

Prince of wales

Rhoda

125

With the lengthening country season, the hardy Chrysanthemums are especially valuable. Their bright colors continue for several weeks after other garden flowers are gone. The variety Eagle d'Or is especially cheerful and bright in its effect.

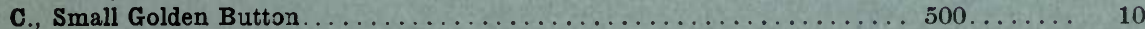

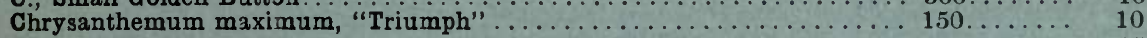

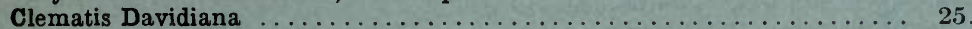

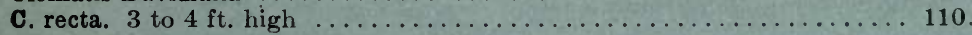

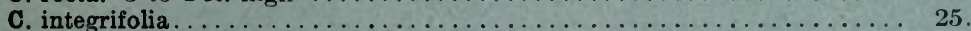

80

80

80

80

500

500

500

500

80

500

Convallaria majalis. Lily-of-the-Valley. Clumps ....... per $1,000, \$ 30 \ldots 2,000$

The low price at which this is offered permits its use in large quantities, and the clumps we send out can be divided to make small splant. There are many places where it is appropriate as a cover plant.

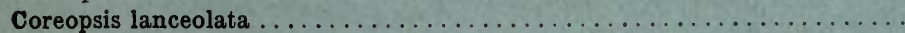

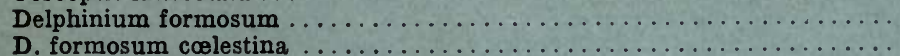

$60 \ldots \ldots 10$

80

600

D. grandiflorum, var. Chinensis

$50 \ldots \ldots \ldots \quad 15 \quad 125$

125

125

An old-time favorite, suitable for edging garden paths.

D. Chinensis. China Pink ...
D. barbatus. Sweet William .

Dark Swet

Pink.

$200 \ldots \ldots$
$400 \ldots \ldots \ldots$

60

500

500

500

$450 \ldots \ldots \ldots 10 \quad 10 \quad 80$

500

D., Homer

Whit

$300 \ldots \ldots \ldots 10$

125

125

150

Dicentra spectabilis. Bleeding Heart.

$25 \ldots \ldots \ldots 15$

$40 \ldots \ldots 20$

D. eximia

A delicate fern-like plant, generally admired by those who see it

in our Nursery. It is suitable for planting in the woods and also fulfils all the requirements of a garden plant, as it has good foliage and flowers all summer.

Dictamnus fraxinella. Gas Plant White

This stately plant is very showy in the garden and is equally appropriate for naturalizing among trees and shrubs.

$25 \ldots \ldots \ldots \quad 20 \quad 150$

$25 \ldots \ldots \ldots \quad 15 \quad 125$

$100 \ldots \ldots+10 \quad 80$

$200 \ldots \ldots .10 \quad 10 \quad$ so

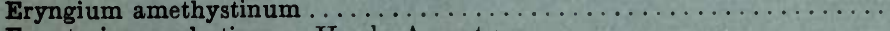

Eupatorium cœlestinum. Hardy Ageratum . . . . . . . . . . . . .

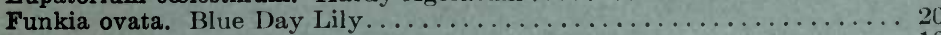

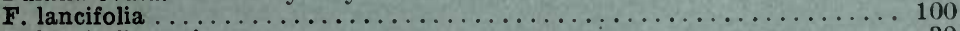

$30 \ldots \ldots \cdots, 15$

F. subcordata grandiflora

This is offered at so low a rate that the opportunity should be 
HARDY GARDEN FLOWERS, GAILLARDIA to MYOSOTIS.

Gaillardia grandiflora. Blanket flower.

There is no plant in the garden to which one may go with more Quantity Each $500 \ldots \ldots \$ 0 . \ldots 0$

Per 10 $\$ 080$

Per 100 confidence of always finding good eut-flowers than to this. The stems are long and the rich bronze, red and yellow flowers will harmonize with most interiors.

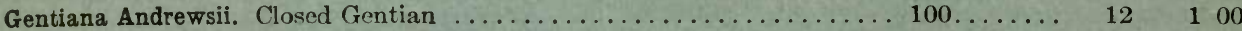

Gypsophila paniculata. Baby's Breath

$20 \ldots \ldots$

15

G. repens

This comparatively unknown plant is valuable as a cover plant.

$90 \ldots \ldots$

10

$\begin{array}{ll}1 & 00 \\ 1 & 25\end{array}$

It makes a tuft of dense, small leaves, elose to the ground.

Helenium autumnale superbum. Sneczeweed

$30 \ldots \ldots \ldots 15$

80

800

600

Helianthus Maximiliana. Sunflower.

This is unusual in gardens, and will be weleomed for its late bloom after hard frosts as well as for its intrinsie beauty.

H. mollis. .

H. rigida, var. Miss Mellish

Heliopsis lævis, var. Pitcheriana.

Hemerocallis fulva. Tawny Day Lily

H. flava.

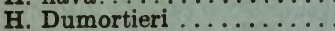

H. Florham

$50, \ldots \ldots \ldots$

125

H. Thunbergii

Hibiscus Moscheutos Marsh Mallow; Rose Mallow .

At the seashore this plant is excellent as its foliage is not browned or broken. Its showy flowers are produced all summer.

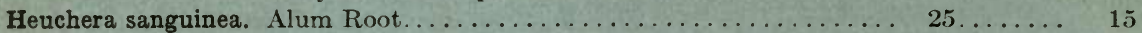

$125 \ldots \ldots \ldots \quad 10$

$25 \ldots \ldots \ldots 15$

$10 \ldots \ldots+15$

$100 \ldots \ldots \ldots 10$

$350 \ldots \ldots 10$

$170 \ldots \ldots 10$

$260 \ldots \ldots .10$

$\begin{array}{rr}100 \ldots \ldots & 25 \\ 25 \ldots \ldots & 15\end{array}$

15

$10 \quad 50$

80
125

$\begin{array}{ll}1 & 25 \\ 1 & 25\end{array}$

125

80

80

80

200

125

50

500

500

500

500

500

500

1500

400

Iberis sempervirens

Iris Germanica. German Iris. Fleur-de-lis.-

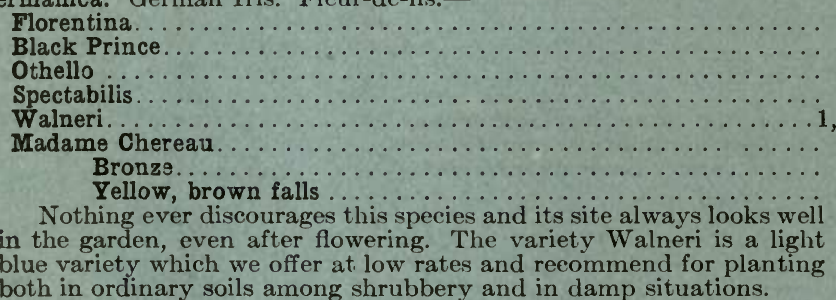

I. pseudo acorus

$240 \ldots \ldots \ldots 10$

$40 \ldots \ldots \ldots 15$

$25 \ldots \ldots \ldots 15$

$10 \ldots \ldots \ldots 15$

$1,500 \ldots \ldots \ldots \quad 10$

$150 \ldots \ldots \ldots 15$

$300 \ldots \ldots 10$

$50 \ldots \ldots 15$

125

80

125

125

125

80

125

125

125

700

500

I. Kæmpferi. Japanese Iris in variety

$25 \ldots \ldots$

125

100

$500 \ldots \ldots$

12

I. cristata

$500 \ldots \ldots \ldots 10$

80

80

800

500

600

Cyanea ............................... $1,000, \$ 40 \ldots 1,700 \ldots \ldots$

80

600

first Iris to bloom and is the most showy flower of its season.

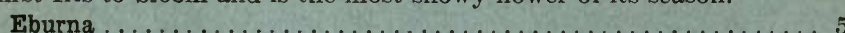

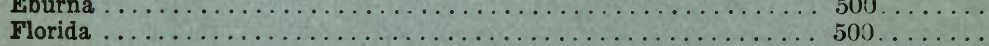

Kniphofia Pfitzeri (Tritoma). Flame Flower; Red-Hot Poker $\ldots \ldots \ldots \ldots \ldots .25 \ldots \ldots$

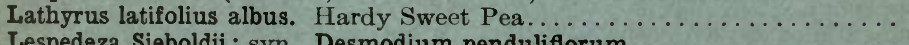

Lespedeza Sieboldii ; syn., Desmodium penduliflorum ...............

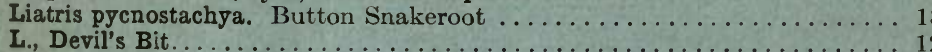

$25 \ldots \ldots$

$85 \ldots \ldots \ldots$

125

$\begin{array}{lrr}20 & 1 & 50 \\ 10 & 80\end{array}$

$125 \ldots \ldots$

10

This is a comparatively rare plant, which attraets eonsiderable

attention in our Nursery, where its tall spikes are one of the most conspicuous flowers of its season, in late summer. It is suitable for the background of the flower-border and also for naturalizing in shrubberies or along the edge of a meadow.

Lilium candidum. Madonna Lily

L. umbellatum

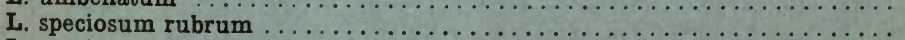

L. speciosum album

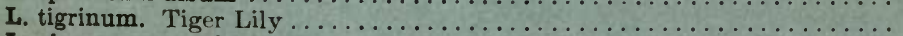

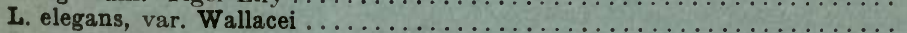

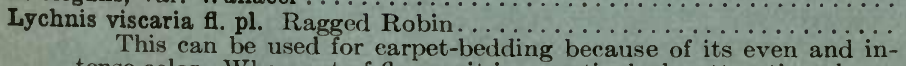
tense color. When out of flower, it is a particularly attraetive elump of grass-like foliage.

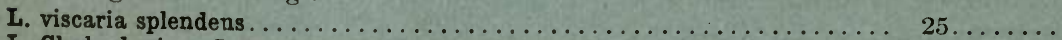

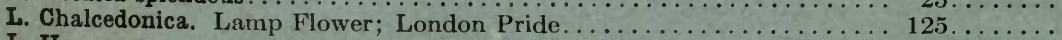

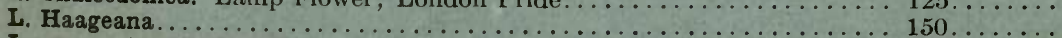

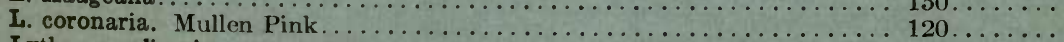

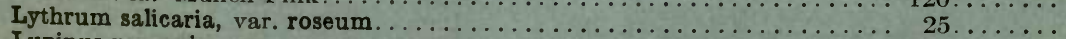

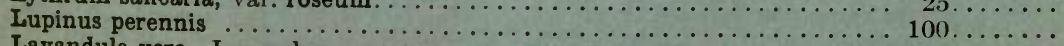

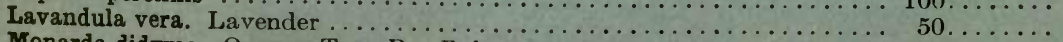

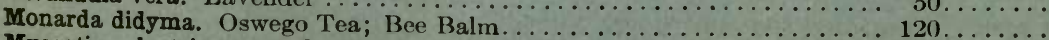

Myosotis palustris semperflorens. Forget-me-not.

$50 \ldots \ldots \ldots 10$ 
HARDY GARDEN FLOWERS, NARCISSUS to YUCCA.

Narcissus, Common Double Yellow.

N. poeticus. Poet's Narcissus

N., Single Yellow

\author{
to YUCCA.
}

\author{
Quantity
Per $1,000, \$ 4.4,000$
yen when in
}

Quantity

250 Each

1,000

03

02

Per 10

So 20

15

Per 100

These clumps can be planted from our Nursery even when in
flower. In the early spring, when they are in bloom, is the time to send us an order for a few thousand to be planted in September. They may be dotted through the grass. The simplest way to plant them is with a sharp stick.

Gnothera Missouriensis. Evening Primrose.

Pæonia Sinensis. Herbaceous Peony

P. Sinensis festiva alba

P. officinalis (Early-flowering Peony) rubrum

P. officinalis roseum

Papaver orientale. Oriental Poppy

Pentstemon barbatus, var. Torreyi

Bright scarlet flower that has no weedy habits and is always at

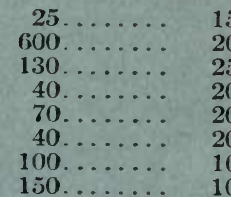
tractive. Height 3 feet.

Phlox decussata

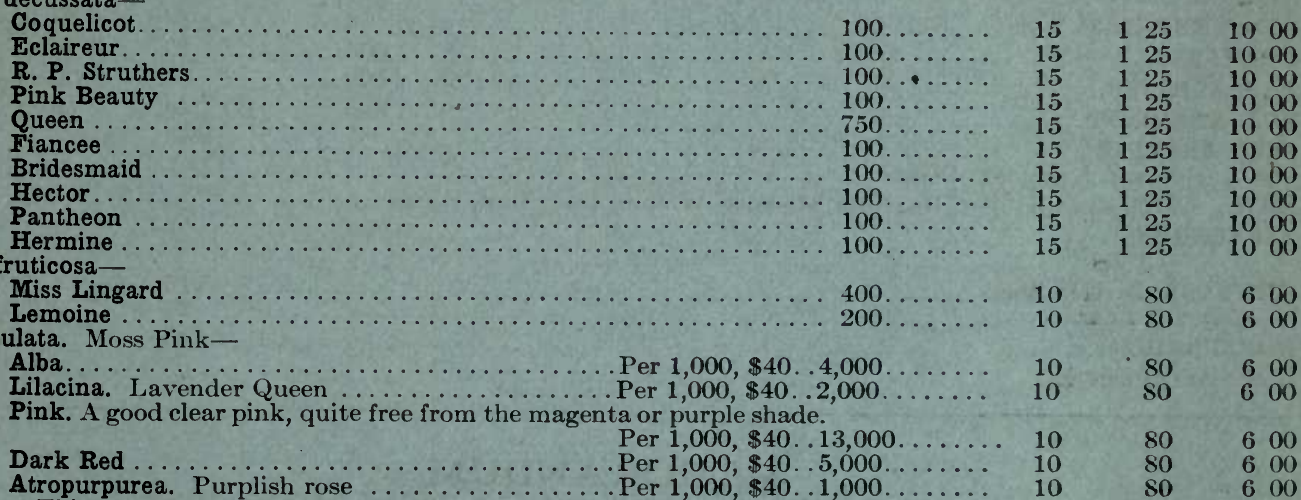

Hermine

$15 \quad 125$

150

200

150

150

180

80

1000

is 00

600

600

P. suffruticosa-

P. subulata. Moss Pink-

Alba.........................

Per $1,000, \$ 40,4,000$

10

80

100

50

000

1000

1000

1000

10 b0

1000

1000

600

00

00

600

600

This could be planted at any time of the season. Our clumps can be torn in pieces and each little piece makes a plant. When planted as a cover plant it holds its own. Mixed with other plants, we have no doubt that is would thrive on the sand bluffs of the north shore of

Long Island, the holding of which is such a serious economic problem.

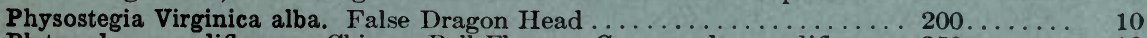

Platycodon grandiflorum. Chinese Bell Flower. Campanula grandiflora. . . 350

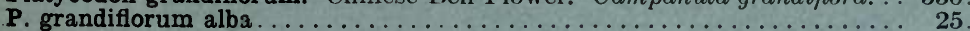

Polemonium Richardsonii. Jacob's Ladder $\ldots \ldots \ldots \ldots \ldots \ldots \ldots \ldots \ldots \ldots \ldots \ldots \ldots \ldots \ldots \ldots \ldots \ldots \ldots \ldots \ldots$
Polygonatum giganteum. Solomon's Seal . $\ldots \ldots \ldots \ldots \ldots \ldots \ldots \ldots \ldots$

Polygonatum giganteum. Solomon's Seal $\ldots \ldots \ldots \ldots \ldots \ldots \ldots \ldots \ldots \ldots \ldots \ldots \ldots \ldots \ldots \ldots \ldots \ldots \ldots \ldots$
Primula veris. English Cowslip $\ldots \ldots \ldots \ldots \ldots \ldots \ldots \ldots$

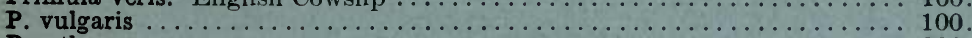

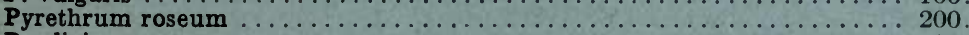

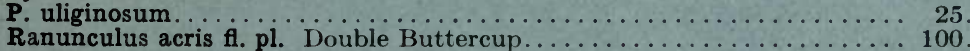

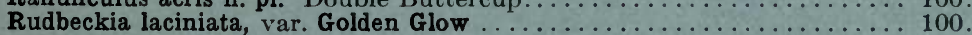

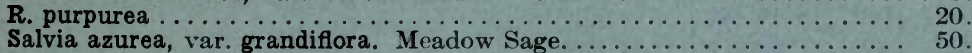

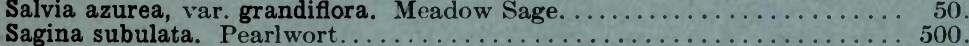

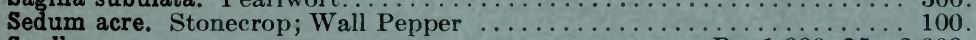

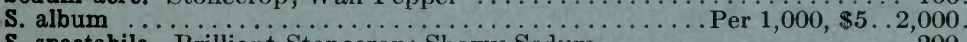

S. spectabile. Brilliant Stonecrop; Showy Sedum $\ldots \ldots \ldots \ldots \ldots \ldots \ldots 200$

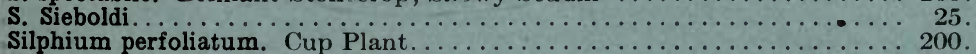

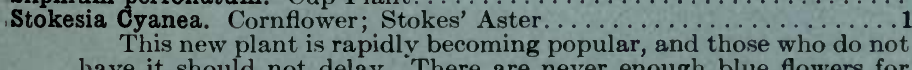
cutting, and this is very welcome, as the color is a clear, azure-blue and it blooms for several months during the summer.

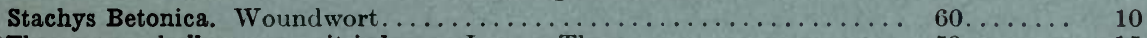

Thymus serphyllum, var. citriodorus. Lemon Thyme.................. $50 \ldots \ldots \ldots$

T. serphyllum, var. variegatus, Golden Thyme $\ldots \ldots \ldots \ldots \ldots \ldots \ldots \ldots \ldots \ldots, 50 \ldots \ldots \ldots \ldots$

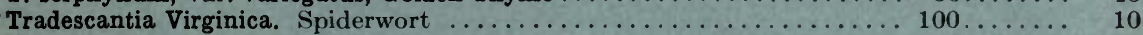

Tricyrtis hirta. Japanese Toad Lily $\ldots \ldots \ldots \ldots \ldots \ldots \ldots \ldots \ldots \ldots \ldots \ldots \ldots \ldots \ldots, 50 \ldots \ldots \ldots \ldots$

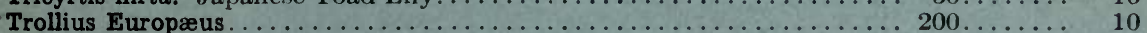

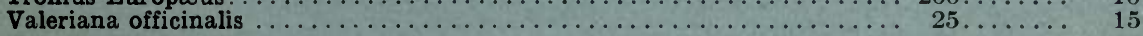

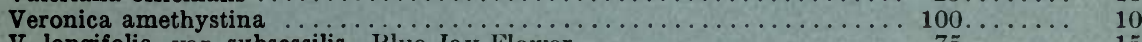

V. longifolia, var. subsessilis. Blue Jay Flower $\ldots \ldots \ldots \ldots \ldots \ldots \ldots \ldots \ldots \ldots \ldots$
V. Dwarf. $\ldots \ldots \ldots \ldots \ldots \ldots \ldots \ldots \ldots \ldots \ldots \ldots \ldots \ldots \ldots \ldots \ldots \ldots$
V.

Vinca minor. Trailing Blue Myrtle. See Broad-leaved Evergreens.

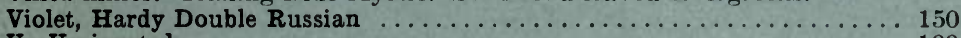

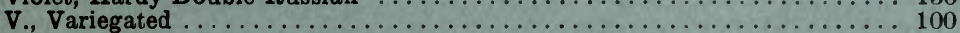

Viola cornuta $\ldots \ldots \ldots \ldots \ldots \ldots \ldots \ldots \ldots \ldots \ldots$
Yucca filamentosa. Sice Broad-leaved Evergreens. 


\section{Fruits}

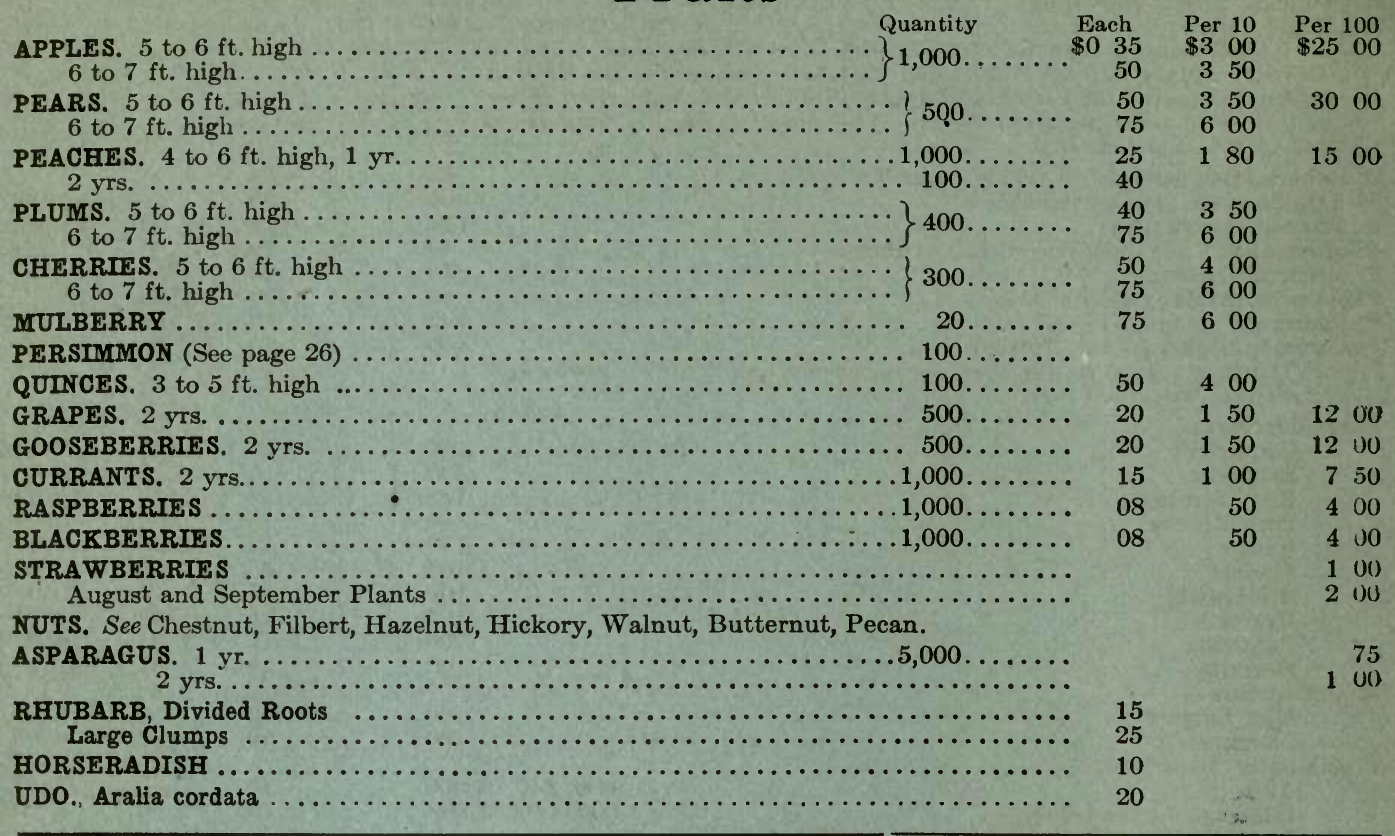

MEMORANDUM 

MEMORANDUM 
32

Isaac Hicks \& Son, Westbury Station, N. Y.

MEMORANDUM 






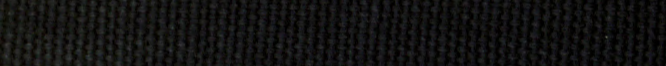

5

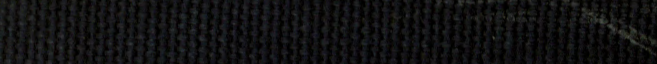

